Mateus Ortigosa Cunha

\title{
RECOMENDAÇÕES PARA PROJETO DE LAJES FORMADAS POR VIGOTAS COM ARMAÇÃO TRELIÇADA
}

Dissertação apresentada à Escola de Engenharia de São Carlos da Universidade de São Paulo, como parte dos requisitos para obtenção do título de Mestre em Engenharia de Estruturas.

Versão corrigida. A original encontra-se na Escola de Engenharia de São Carlos da Universidade de São Paulo, EESC-USP.

ORIENTADOR: Mounir Khalil EI Debs

São Carlos - SP

2012 
AUTORIZO A REPRODUÇÃO TOTAL OU PARCIAL DESTE TRABALHO, POR QUALQUER MEIO CONVENCIONAL OU ELETRÔNICO, PARA FINS DE ESTUDO E PESQUISA, DESDE QUE CITADA A FONTE.

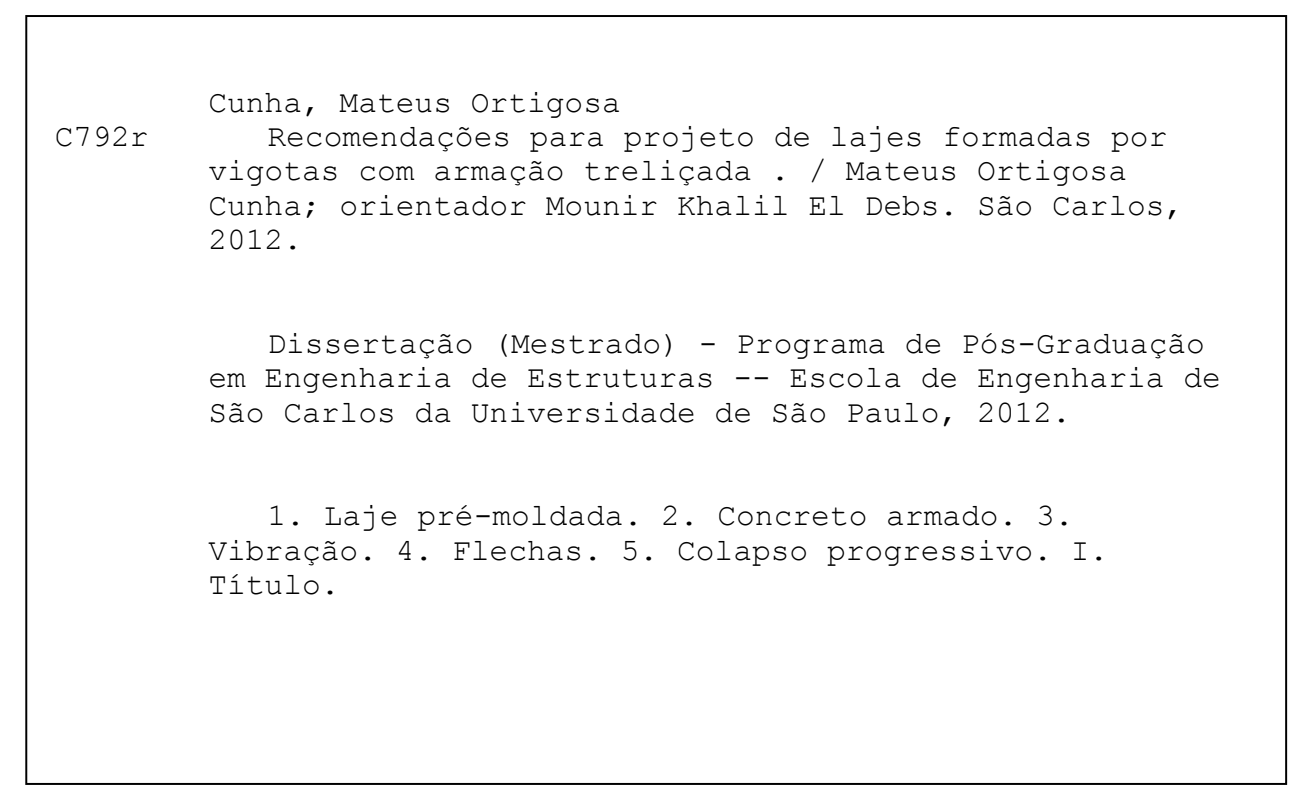




\section{FOLHA DE JULGAMENTO}

Candidato: Engenheiro MATEUS ORTIGOSA CUNHA.

Título da dissertação: "Recomendações para projeto de lajes formadas por vigotas com armação treliçada".

Data da defesa: 09/08/2012

\section{Comissão Julgadora:}

Resultado:

Prof. Titular Mounir Khalil El Debs (Orientador)

(Escola de Engenharia de São Carlos/EESC)

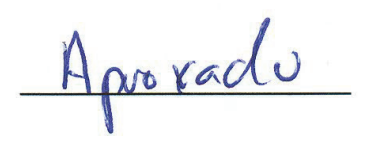

Prof. Dr. José Samuel Giongo

(Escola de Engenharia de São Carlos/EESC)

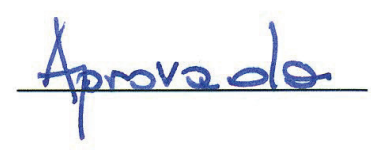

Prof. Dr. Jasson Rodrigues de Figueiredo Filho

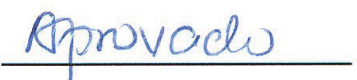

(Universidade Federal de São Carlos/UFSCar)

Coordenador do Programa de Pós-Graduação em Engenharia Civil (Engenharia de Estruturas):

Profa. Associada Ana Lucia Homce de Cresce El Debs

Presidente da Comissão de Pós-Graduação:

Prof. Titular Denis Vinicius Coury 

À minha família, meus pais

Mário e Izabel, e minhas irmãs

Débora e Carolina. 



\section{AGRADECIMENTOS}

Primeiramente a Deus por iluminar meu caminho nesta jornada.

Á minha família, em especial meus pais, Mário e Izabel e, minhas irmãs, Débora e Carolina, pelo amor, carinho, incentivo e auxílio durante todos os momentos da minha vida.

Ao meu avô Mário da Cunha, grande homem, trabalhador e músico. Um espelho para mim por toda a minha vida. À minha avó Gilda (in memorian). Sempre me lembrarei dos seus conselhos e de sua afetividade.

Aos meus tios, tias, primos e primas, pelo incentivo e carinho.

Ao prof ${ }^{0}$ Mounir pela compreensão, orientação e confiança depositada em mim durante todo o desenvolvimento do trabalho.

À todos os funcionários e professores do Departamento de Engenharia de Estruturas da Escola de Engenharia de São Carlos (USP), em especial aos professores Francisco Antonio Rocco Lahr e José Samuel Giongo, pelas conversas francas e descontraídas.

Aos colegas da turma de 2009 do mestrado do Departamento de Engenharia de Estruturas.

A todos meus amigos e colegas que participaram da minha jornada para o mestrado durante o período da graduação. Por propiciar momentos de alegria e descontração.

Aos meus grandes amigos e colegas Alexandre Seiiti Arita e Anderson Ramos Amorim, grandes incentivadores e parceiros durante toda a minha vida acadêmica até hoje.

Aos meus parceiros, engenheiros e desenhistas do Escritório Técnico J.R. Andrade: Betão e Beto Andrade, Renata, Carlos, José Carlos, Ailton, Carol e Célia. 

"A educação é a arma mais poderosa que você pode usar para mudar o mundo"

Nelson Mandela 

CUNHA, M.O. Recomendações para projeto de lajes formadas por vigotas com armação treliçada. 119p. 2012. Dissertação (Mestrado) Escola de Engenharia de São Carlos, Universidade de São Carlos, São Carlos, 2012.

As lajes formadas por vigotas pré-moldadas são utilizadas em larga escala no Brasil, em especial as formadas por vigotas treliçadas. As facilidades no manuseio e economia de fôrmas são algumas das vantagens do sistema. Apesar de serem muito utilizadas, ainda existe necessidade de estudo das recomendações no sentido de basear o projeto destas lajes. Os objetivos deste trabalho são: (a) contribuir no projeto de lajes formadas por vigotas com armação treliçadas através de uma análise crítica da bibliografia pesquisada; (b) tratar de temas pouco disseminados no que se refere ao cálculo de lajes pré-moldadas; (c) fornecer recomendações de projeto através de exemplo resolvido que aborda as principais dúvidas de projetistas da área. Neste exemplo avaliam-se as lajes, entre outros aspectos, quanto às flechas iniciais e ao longo do tempo, vibrações e momento negativo nos apoios. Os resultados são analisados e confrontados com as indicações da bibliografia. Comprova-se o fato destas lajes serem mais susceptíveis quanto às vibrações causadas por caminhada e mostra a dificuldade em atender à ABNT NBR 6118:2003. O vão máximo admissível para uma laje do exemplo de aplicação é $28 \%$ inferior quando comparado à laje maciça de mesma espessura na análise da vibração excessiva. Enfatiza a importância em prever armadura contra o colapso progressivo e demonstra que o aumento de consumo de aço em $5 \%$ é pequeno quando comparado ao total, para uma laje do exemplo de aplicação.

Palavras-chave: Laje pré-moldada. Concreto armado. Vibração. Flechas. Colapso progressivo. 



\section{ABSTRACT}

CUNHA, M.O. Recommendations for design of slabs with lattice reinforcement. 2012. 119p. Dissertation (Master) - Escola de Engenharia de São Carlos, Universidade de São Carlos, São Carlos, 2012.

Precast slabs are used in large scale in Brazil, special those formed by lattice reinforcement. Facilities handling and economy mold are some of the advantages of the system. The objectives of this work are: (a) improve study of the design of slabs formed by precast lattice reinforcement through a review of literature; (b) address topics a little spread regards to the calculation of precast slabs; (c) providing design recommendations through examples solved by addressing the main concerns of designers in the area. This example evaluate the slabs to initials and long-term deflections, vibrations and bending moment at the supports. The results are analyzed and compared with indications in the literature. It demonstrates the suscetibility of the slabs for vibrations caused by walking and shows the difficulty in following ABNT NBR 6118:2003. The maximum span for one slab of the aplication example is $28 \%$ slower than solid slabs with the same thickness in excessive vibration analysis. This dissertation emphasizes the importance of predicting reinforcement against progressive collapse and shows the increase in steel consumption is small compared to the total, for one slab of the example.

Keywords: Precast slabs. Reinforcement concrete. Vibration. Deflections. Progressive collapse. 



\section{LISTA DE FIGURAS}

Figura 2.1 Laje formada por vigotas pré-moldadas (EL DEBS, 2000)...................

Figura 2.2 Tipos de vigotas pré-moldadas (DROPPA JR., 1999).........................

Figura 2.3 Vigota com armação treliçada..........................................................

Figura 2.4 Perspectiva de uma treliça (Manual de Fabricação das lajes PUMA,

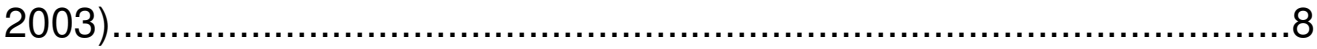

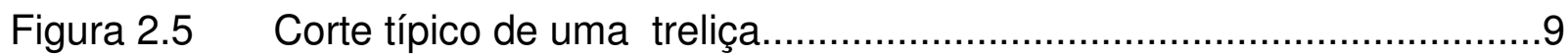

Figura 2.6 Foto do conjunto vigota treliçada e bloco cerâmico................................9

Figura 2.7 Forma para vigota recebendo óleo anti-aderente (Manual de

Fabricação das lajes PUMA, 2003)..................................................10

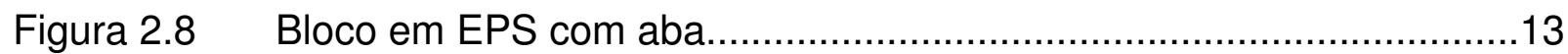

Figura 2.9 Canaleta para nervuras transversais construtivas .............................14

Figura 2.10 Canaleta para nervuras transversais construtivas na laje.....................14

Figura 2.11 Importância da nervura de travamento (AVILLA JR., 2009)................15

Figura 2.12 Seções transversais das lajes, em cm (MERLIN, 2006)......................20

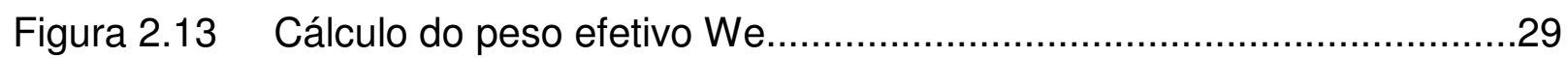

Figura 2.14 Aceleração máxima aceitável para o conforto humano em diferentes ambientes, em função da freqüência (adaptado de MAST, 2001)........31

Figura 2.15 Seção "T" para momento positivo.....................................................34

Figura 2.16 Seção retangular para momento negativo.........................................34

Figura 2.17 Perímetro de contato entre concretos (EF-96:1997)...........................38

Figura 2.18 Planta de formas do experimento, em cm (MAGALHÃES, 2001).........39

Figura 2.19 Seção transversal do elemento estrutural, em cm (MAGALHÃES,

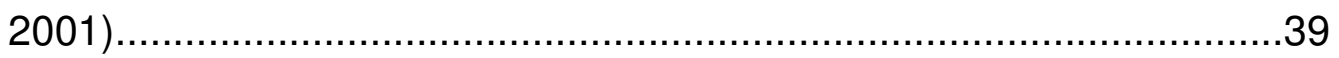

Figura 2.20 Colapso de Ronan Point, Inglaterra, em 1968 (TAYLOR et al., 2010)..41

Figura 2.21 Formação da ação de membrana na laje (adaptado de ZHANG et al, 2009)

Figura 2.22 Ação de membrana em lajes sem restrição horizontal em seu perímetro (adaptado de BAILEY, 2004).

Figura 2.23 Diferentes tipos de tirantes incorporados para prover a integridade estrutural (NISTIR 7396). 
Figura 2.24 Combinação de carregamentos (EN 15037-1:2004).....................54

Figura 2.25 Concorrência de nervuras (EF-96: 1997).................................55

Figura 2.26 Encontro de vigotas perpendiculares (EF-96: 1997)...................55

Figura 2.27 Apoio direto sobre vigas (EF-96: 1997)..................................56

Figura 2.28 Apoio indireto: ligação por penetração (EF-96: 1997)...................56

Figura 2.29 Apoio indireto: ancoragem por prolongação ou transpasse (EF-96: 1997).

Figura 2.30 Apoio indireto: treliça adicional sobre a vigota (EN 15037-1:2004). .57

Figura 2.31 Apoio da vigota treliçada nas vigas (CEB-FIP, 1998). .58

Figura 2.32 Apoio da vigota treliçada (EUROCODE EN 15037-1:2004, anexo D) 58

Figura 2.33 Número de dias para a cura do concreto em função da temperatura e da umidade relativa (adaptado de CEB-FIP, 1998) .59

Figura 3.1 Espessuras mínimas das lajes formadas por vigotas pré-moldadas (EF-96). 66

Figura 3.2 Largura mínima da nervura (EF-96). 67

Figura 3.3 Distribuição transversal de cargas concentradas ou lineares (EF-96). .69

Figura 3.4 Área necessária da armação da capa para cargas concentradas (EF-96). .70

Figura 3.5 Área necessária da armação da capa para cargas lineares (EF-96).

Figura 4.1 Pavimento em alvenaria estrutural com lajes maciças de concreto. .78

Figura 4.2 Formas do pavimento a ser analisado (sem escala).....................79

Figura 4.3 Lajes a serem analisadas (sem escala)....................................79

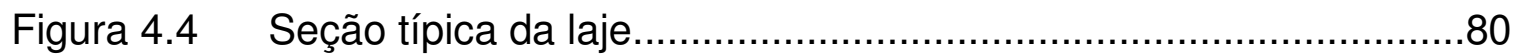

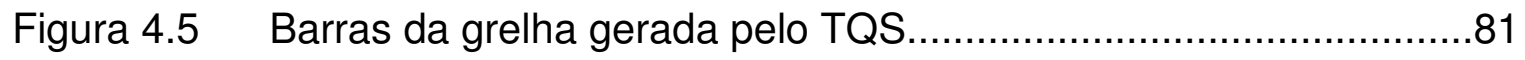

Figura 4.6 Momentos fletores das lajes L1 e L3, com e sem redistribuição....83

Figura 4.7 Flechas iniciais da análise linear pelo TQS ................................87

Figura 4.8 Flechas iniciais da análise não-linear pelo TQS............................88

Figura 4.9 Flechas iniciais da análise linear pelo TQS para lajes maciças......89 
Figura 4.10 Flechas iniciais da análise não-linear pelo TQS para lajes maciças.........89

Figura 4.11 Gráfico das freqüências ao longo dos vãos da LT10 (7+3) ...................96

Figura 4.12 Gráfico das freqüências ao longo dos vãos para laje maciça..................97

Figura 4.13 Gráfico das freqüências ao longo dos vãos da LT12 (8+4)..................99

Figura 4.14 Trecho do pavimento para cálculo do tirante...................................101

Figura 4.15 Detalhamento da armadura contra o colapso progressivo (corte na

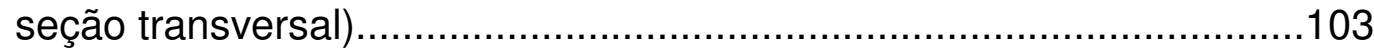





\section{LISTA DE TABELAS}

Tabela 2.1 Valores das flechas para tramo de 6m (SANTINI et al., 2004)..........17

Tabela 2.2 Valores de $\gamma_{\mathfrak{f} 2}$ (tabela 11.2, NBR 6118:2003) ..................................18

Tabela 2.3 Coeficientes obtidos por MERLIN (2006) para os exemplos realizados............................................................................... 22

Tabela 2.4 Constante "R" de acordo com a vinculação....................................26

Tabela 2.5 Valores de Fe $\zeta$ (MAST, 2001)............................................28

Tabela 2.6 Valores estimados dos coeficientes dinâmicos, de acordo com a finalidade (MURRAY et al., 1997) ..............................................30

Tabela 2.7 Valores limites recomendáveis de aceleração para atividades rítmicas (MAST, 2001).

Tabela 2.8 Freqüência crítica para alguns locais submetidos à vibração pela ação humana (NBR 6118:2003).

Tabela 2.9 Tempos requeridos de resistência ao fogo (TRRF), em minutos. (tabela A.1, NBR 14432:2001).... .48

Tabela 2.10 Dimensões mínimas para lajes apoiadas em vigas (NBR 15200:2004) .50

Tabela 2.11 Dimensões mínimas para lajes lisas ou cogumelos (NBR 15200:2004) .50

Tabela 2.12 Dimensões mínimas para lajes nervuradas biapoiadas (NBR 15200:2004). 50

Tabela 2.13 Dimensões mínimas para lajes nervuradas apoiadas em três ou quatro lados (NBR 15200:2004)

Tabela 2.14 Dimensionamento da laje (tabela 1: GOMIDE et al.,2009). .51

Tabela 2.15 Comparação entre momentos atuantes e resistentes (tabela 3: GOMIDE et al., 2009). .52

Tabela 3.1 Intereixos mínimos padronizados (NBR 14859-1:2002).................65

Tabela 3.2 Altura padronizada da laje (NBR 14859-1:2002). .65

Tabela 3.3 Escolha da altura da laje em função da carga e vão livre máximo (CARVALHO e FIGUEIREDO FILHO, 2005). 67

Tabela 3.4 Coeficientes C (EF-96:1997). .68 
Tabela 3.5 Valores de altura de laje $(\mathrm{em} \mathrm{cm})$ para vão de 4,0m e carga de $4,0 \mathrm{kN} / \mathrm{m}^{2}$

Tabela 3.6 Área mínima e quantidade de armadura de distribuição (item 5.6 - NBR 14859-1/2002). .88

Tabela 3.7 Coeficientes de distribuição das cargas concentradas ou lineares 89

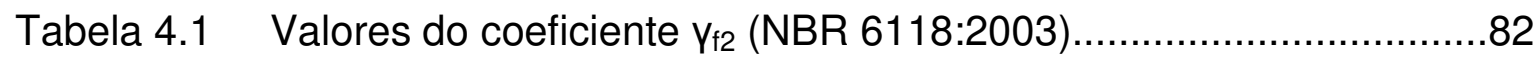

Tabela 4.2 Momento fletor positivo e flecha para a laje L3 .............................86

Tabela 4.3 Tabela resumo das flechas iniciais máximas para a laje L3............90

Tabela 4.4 Dados do exemplo de aplicação...................................................

Tabela 4.5 Análise determinística (MERLIN, 2006).......................................91

Tabela 4.6 Análise probabilística (MERLIN, 2006)......................................92

Tabela 4.7 Tabela resumo das flechas diferidas ao longo do tempo.................93

Tabela 4.8 Frequência mínima e natural para LT10 $(7+3) \ldots \ldots \ldots \ldots \ldots \ldots \ldots \ldots \ldots \ldots \ldots . . . . .95$

Tabela 4.9 Frequência mínima e natural para laje maciça de $10 \mathrm{~cm}$................97

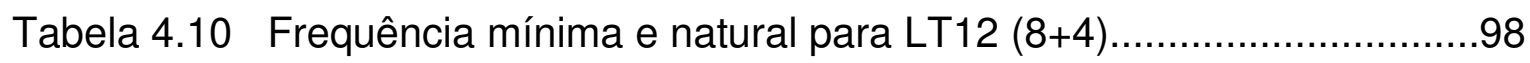

Tabela 4.11 Tabela resumo da análise de vibração excessiva...........................99

Tabela 4.12 Consumo de materiais das opções de lajes maciças e prémoldadas para o pavimento analisado. .104 




\section{SUMÁRIO}

\section{CAPÍTULO 1 - INTRODUÇÃO}

1.1. Considerações iniciais ........................................................................... 1

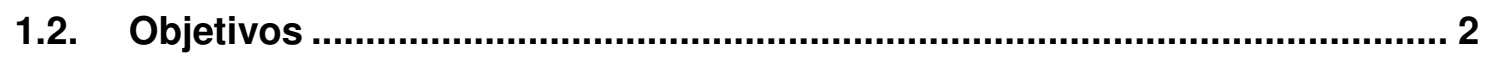

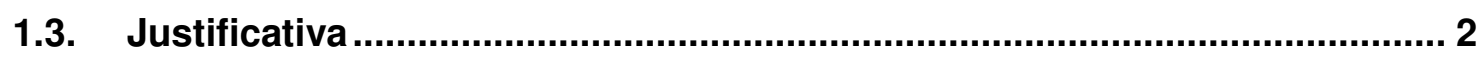

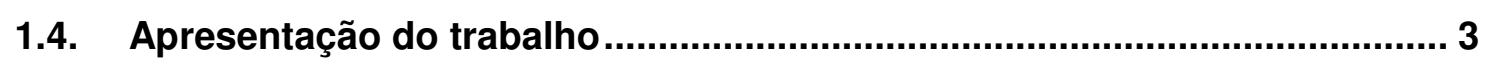

\section{CAPÍTULO 2 - REVISÃO BIBLIOGRÁFICA}

2.1. CONSIDERAÇÕES INICIAIS .................................................................. 5

2.2. VIGOTAS COM ARMADURA TRELIÇADA ............................................... 7

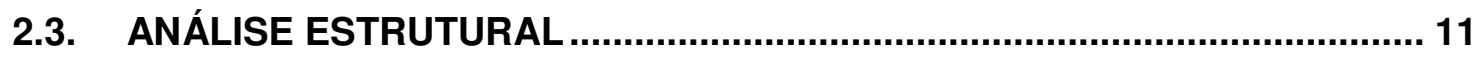

2.3.1. Comportamento unidirecional $x$ bidirecional ...................................... 11

2.3.2. Vigas de borda ............................................................................... 11

2.3.3. Nervuras transversais em lajes unidirecionais .................................. 12

2.3.4. Nervuras transversais em lajes bidirecionais..................................... 12

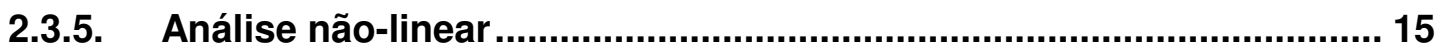

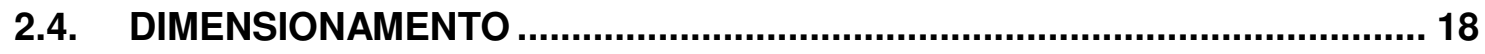

2.4.1. Estados Limites de Serviço ............................................................ 18

2.4.1.1. Estado Limite de Deformações Excessivas (ELS-DEF).................... 19

2.4.1.2. Estado Limite de Vibrações Excessivas (ELS-VE).......................... 23

2.4.2. Estado Limite Último ....................................................................... 33

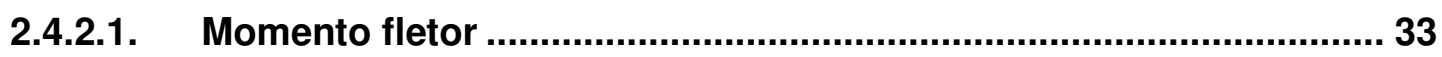

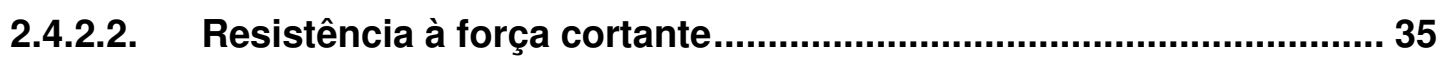

2.4.2.3. Verificação do cisalhamento na interface ...................................... 37

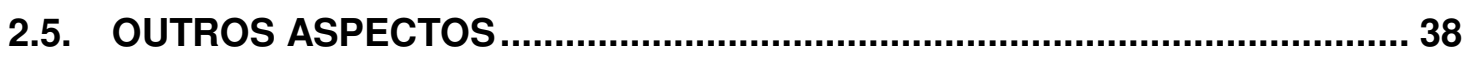

2.5.1. Momento fletor negativo nos apoios................................................... 38

2.5.2. Colapso progressivo ........................................................................ 41

2.5.3. Verificação em situação de incêndio................................................... 46

2.5.4. Comportamento estrutural na fase de montagem............................. 52

2.5.5. Disposições construtivas.............................................................. 54

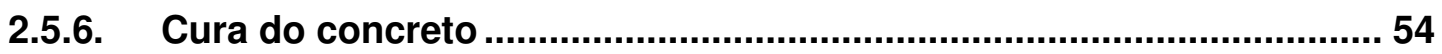




\section{CAPÍTULO 3 - RECOMENDAÇÕES DE PROJETO}

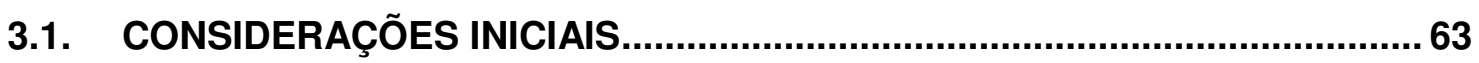

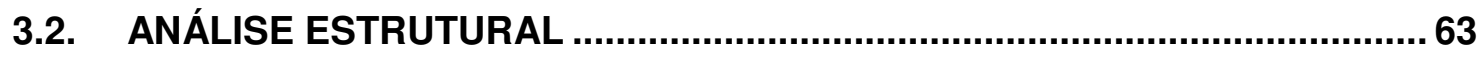

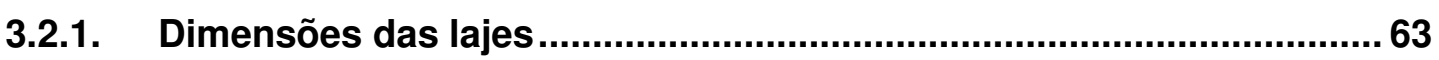

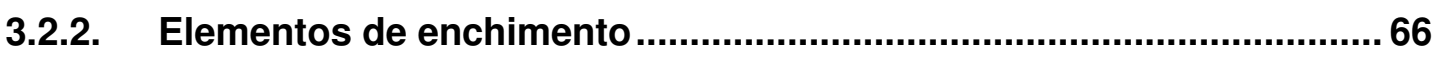

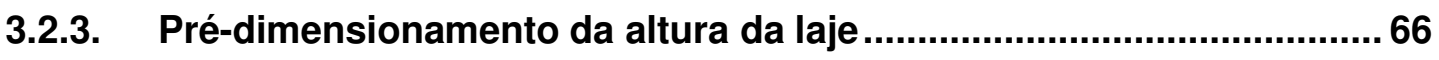

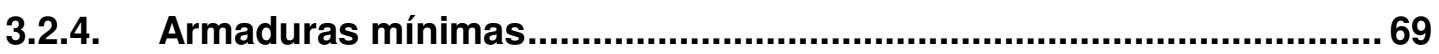

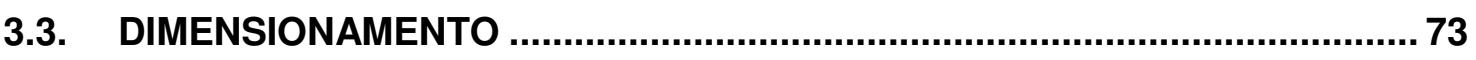

3.3.1. Estado Limite de Serviço (E.L.S.)................................................................ 74

3.3.2. Estado Limite Último (E.L.U.) .................................................................. 74

\section{CAPÍTULO 4 - EXEMPLO DE APLICAÇÃO}

4.1. CONSIDERAÇÕES INICIAIS......................................................................

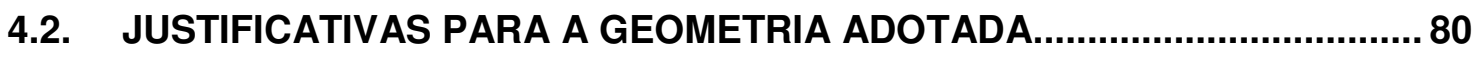

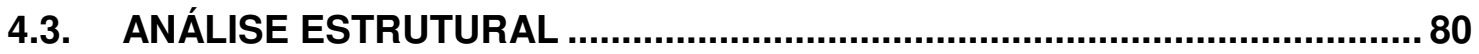

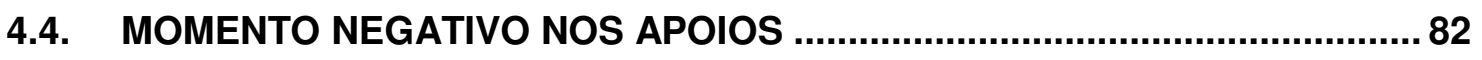

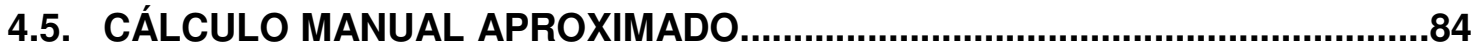

4.6. ESTADO LIMITE DE DEFORMAÇÕES EXCESSIVAS (ELS-DEF) ................. 87

4.7. FLECHA DIFERIDA AO LONGO DO TEMPO SEGUNDO MERLIN (2006) ... 90

4.8. ANÁLISE DO ESTADO LIMTE DE VIBRAÇÕES EXCESSIVAS ....................93

4.9. CÁLCULO DE ARMADURA CONTRA O COLAPSO PROGRESSIVO ........ 100

4.10. COMPARAÇÃO ENTRE CONSUMO DE MATERIAIS: LAJE

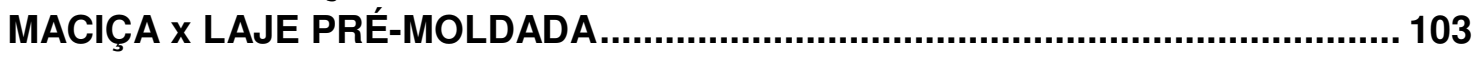

4.11. SÍNTESE DOS RESULTADOS E ANÁLISES ……….................................. 104

CAPÍTULO 5 - CONSIDERAÇÕES FINAIS E CONCLUSÕES ... 107 




\section{INTRODUÇÃO}

\subsection{Considerações iniciais}

As lajes formadas por vigotas são muito empregadas em construções de pequeno e médio porte no Brasil. Principalmente as vigotas com armação treliçada. Como a sua fabricação é simples e não envolve equipamentos caros ou de difícil manutenção, estas vigotas se tornam uma opção bem acessível. São muitas as vantagens na sua utilização, dentre elas facilidade de manuseio e economia com fôrmas. Da mesma forma que o emprego destas lajes foi crescendo as pesquisas relacionadas também seguiram o mesmo percurso.

Particularmente no Departamento de Engenharia de Estruturas da Escola de Engenharia de São Carlos, desde o fim da década de 1990, pesquisas vêm sendo realizadas sobre o comportamento de lajes formadas por vigotas de três tipos: de concreto armado, protendidas e treliçadas. Droppa Jr. (1999) iniciou as pesquisas sobre o assunto. No entanto, boa parte dos profissionais responsáveis pelo dimensionamento destes elementos estruturais não tem conhecimento dos resultados obtidos de ensaios experimentais e teóricos desenvolvido pelo meio acadêmico.

A principal desvantagem da utilização desta laje é a maior propensão a atingir o estado limite por deformações excessivas comparado às lajes maciças. Muitas vezes a verificação da flecha é predominante sobre o estado limite último de ruína da laje, seja por ação do momento fletor ou força cortante. Temas pouco abordados e que estão relacionados ao dimensionamento destas lajes serão apresentados e discutidos como o colapso progressivo, as estruturas em 
situação de incêndio, as vibrações excessivas e as flechas diferidas ao longo do tempo. A abordagem destes temas tem como objetivo alertar o engenheiro de estruturas e começar uma discussão com entidades de classe, meio acadêmico e meio técnico. Principalmente, quando se fala em colapso progressivo, já que não há indicações explícitas e diretas sobre como considerá-lo no cálculo e no dimensionamento de lajes formadas por vigotas treliçadas.

\subsection{Objetivos}

O objetivo geral deste trabalho é de contribuir para o projeto de lajes formadas por vigotas treliçadas pré-moldadas através de uma análise crítica da bibliografia pesquisada e de exemplos resolvidos.

Os objetivos específicos são:

- Fornecer recomendações de projeto através de exemplos resolvidos que abordarão as principais dúvidas de projetistas da área.

- Auxiliar de forma prática no cálculo de lajes formadas por vigotas prémoldadas

- Tratar de temas pouco disseminados no que se refere ao cálculo de lajes pré-moldadas.

- Reunir todas as pesquisas relevantes a respeito do assunto.

- Melhorar a qualidade dos projetos estruturais nacionais de lajes formadas por vigotas treliçadas

\subsection{Justificativa}

É fato notório que pesquisas têm sido feitas no campo das lajes prémoldadas, no Brasil. Entretanto, não há a incorporação destas conclusões nos escritórios de engenharia civil no país. As normas brasileiras não apresentam todos os detalhes necessários para um bom projeto de lajes formadas por vigotas pré-moldadas. 
A importância e relevância deste trabalho é a de reunir todas estas informações e apresentá-las de forma prática e crítica, acrescida de recomendações de projeto.

\subsection{Apresentação do trabalho}

Esta dissertação será dividida em cinco capítulos, apresentada de forma sucinta a seguir:

O capítulo 2 apresenta a revisão da bibliografia seguindo os tópicos de análise estrutural, dimensionamento, estados limites de serviço, estados limites últimos e outros aspectos relevantes às lajes em questão.

O capítulo 3 detalha as recomendações de projeto para as lajes formadas por vigotas com armação treliçada.

O capítulo 4 mostra exemplos de aplicação resolvidos e analisa criticamente os resultados obtidos referenciando-os à bibliografia previamente apresentada e às normas vigentes, nacionais e internacionais. A ênfase será nos problemas mais comuns das lajes formadas por vigotas treliçadas, além de questões mais recentes como o colapso progressivo.

No capítulo 5 são apresentadas as conclusões obtidas com o trabalho, considerações e recomendações finais. Indica também sugestões para trabalhos futuros. 



\subsection{CONSIDERAÇÕES INICIAIS}

Segundo Muniz (1991) as lajes treliçadas surgiram a partir da Segunda Guerra Mundial e tiveram larga utilização em países europeus, ajudando-os na reconstrução e na diminuição do déficit habitacional subseqüente.

As lajes formadas por vigotas pré-moldadas são constituídas por elementos pré-fabricados lineares, elementos de enchimento e concreto moldado no local (figura 2.1). Podem ser unidirecionais ou bidirecionais. $O$ elemento pré-moldado, também denominado de vigota pré-moldada, pode ser encontrado em concreto armado (VC) de seção $T$ invertida, em concreto protendido (VP) e em forma de treliça em uma base de concreto (VT). A figura 2.2 ilustra os tipos de vigotas com a sigla correspondente, como mostra a ${ }^{1} \mathrm{ABNT}$ NBR 14859-1:2002. Os elementos de enchimento podem ser de blocos cerâmicos, blocos de concreto ou blocos de poliestireno expandido.

São bastante empregadas em construções de pequeno a médio porte, devido à facilidade de fabricação, manuseio e transporte. Destacam-se também pela economia com fôrmas e escoramentos, além de redução no consumo de materiais. Proporcionam diminuição no peso próprio e acarreta na economia das fundações. As principais desvantagens são: maiores deformações ao longo do tempo quando comparados às lajes maciças e dificuldade na execução de instalações prediais (CARVALHO e FIGUEIREDO FILHO, 2005).

\footnotetext{
${ }^{1} \mathrm{O}$ termo NBR refere-se às normas da Associação Brasileira de Normas Técnicas (ABNT) e estão presentes nas Referências bibliográficas deste trabalho. O termo ABNT será omitido nas próximas citações.
} 


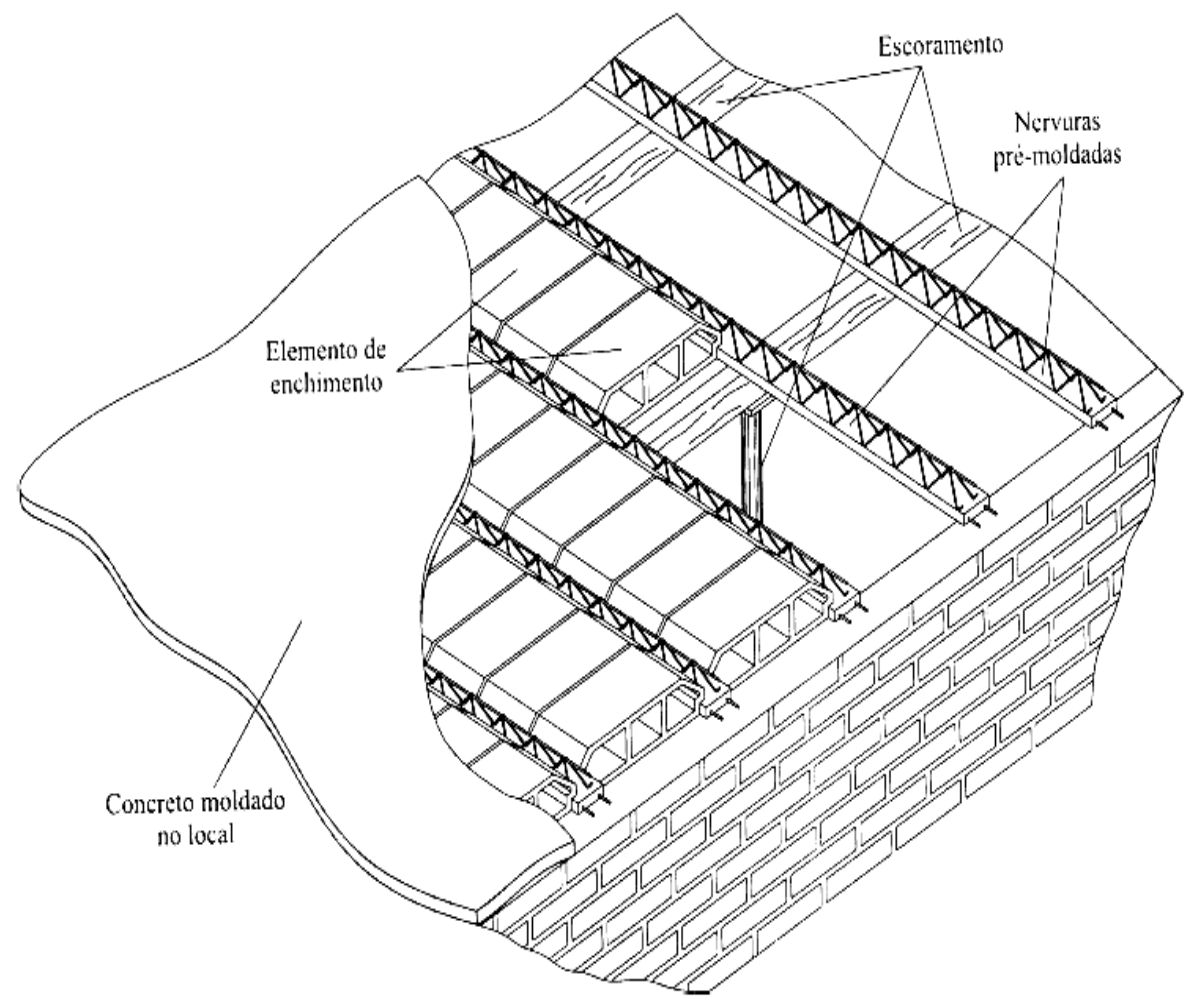

Figura 2.1 - Laje formada por vigotas pré-moldadas (EL DEBS, 2000)

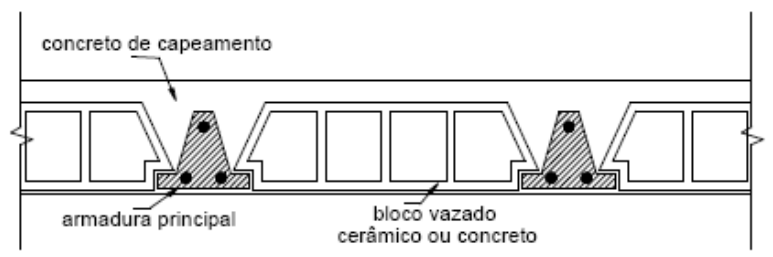

vigota de concreto armado comum (VC)

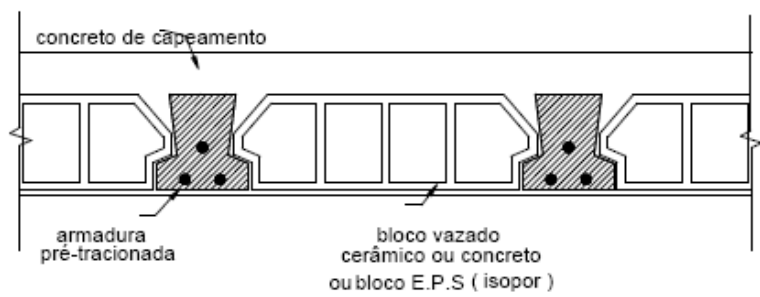

vigota de concreto armado protendido (VP)

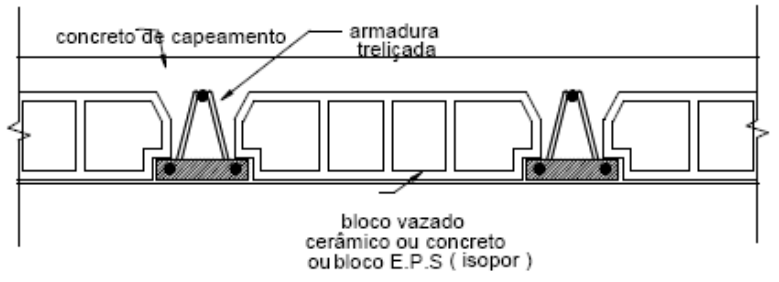

vigota com armadura treliçadia (VT)

Figura 2.2 - Tipos de vigotas pré-moldadas (DROPPA JR., 1999) 
Carvalho et al. (2005) aponta alguns conceitos que precisam ser melhor estudados através de pesquisas experimentais, tais como:

- Cisalhamento e verificação das armaduras inclinadas da armação treliçada;

- Plastificação de seções nos apoios;

- Estudos para utilização de cobrimentos menores;

- Processo simples para verificar flechas ao longo do tempo com precisão.

\subsection{VIGOTAS COM ARMADURA TRELIÇADA}

Dentre os três tipos de vigotas anteriormente citados, destacam-se aquelas com armação treliçada. Estas fazem parte das lajes que são objeto de estudo deste trabalho.

Tais vigotas são formadas por: base de concreto e armação treliçada. Quando necessário é possível inserir uma armação adicional referente ao dimensionamento da laje. A figura 2.3 mostra os elementos constituintes da vigota. As treliças utilizam fios de aço CA-60 soldados por eletrofusão e são constituídas por um fio superior (banzo superior), dois fios inferiores, (banzo inferior) e diagonais, ou chamadas também por sinusóides. Estas são soldadas a cada $20 \mathrm{~cm}$ nos fios superiores, de acordo com a figura 2.4. A NBR 14862:2002 padroniza tais treliças e são nomeadas em função da sua altura e bitolas utilizadas (figura 2.5). Como exemplo, pode-se citar a treliça TR 8644: 8,0cm de altura, fio superior com $6,0 \mathrm{~mm}$ de diâmetro, diagonal com $4,2 \mathrm{~mm}$ de diâmetro e fio inferior com $4,2 \mathrm{~mm}$ de diâmetro. Geralmente são produzidas em três comprimentos: 8,10 e 12 metros.

A medida da base de concreto das vigotas com armação treliçada varia de $12 \mathrm{~cm}$ a $13 \mathrm{~cm}$ de largura e $3 \mathrm{a} 4 \mathrm{~cm}$ de altura. $O$ concreto estrutural utilizado deve ter no mínimo uma resistência característica à compressão de $20 \mathrm{MPa}$, para concretos com armadura passiva. Alerta deve ser feito para o ambiente Há a possibilidade de conter ainda uma armadura adicional, encomendada e colocada a pedido do engenheiro civil responsável pelo cálculo estrutural. A figura 2.6 ilustra o conjunto da vigota com armação treliçada e bloco cerâmico. 


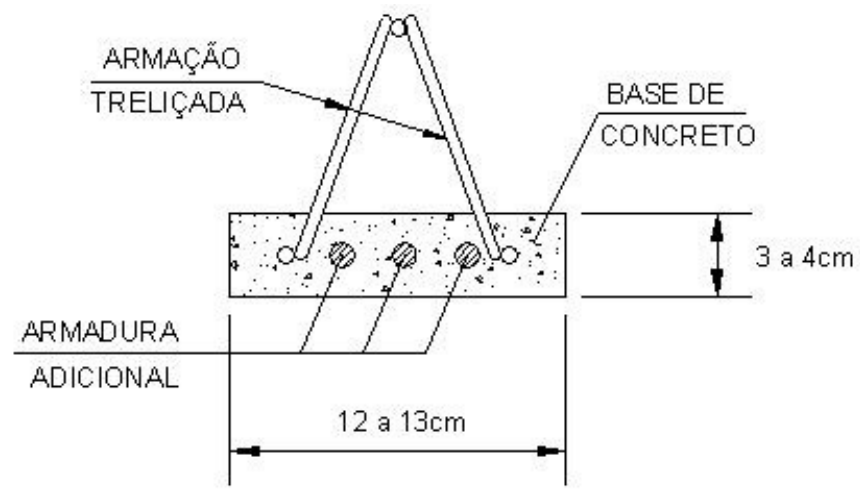

Figura 2.3 - Vigota com armação treliçada

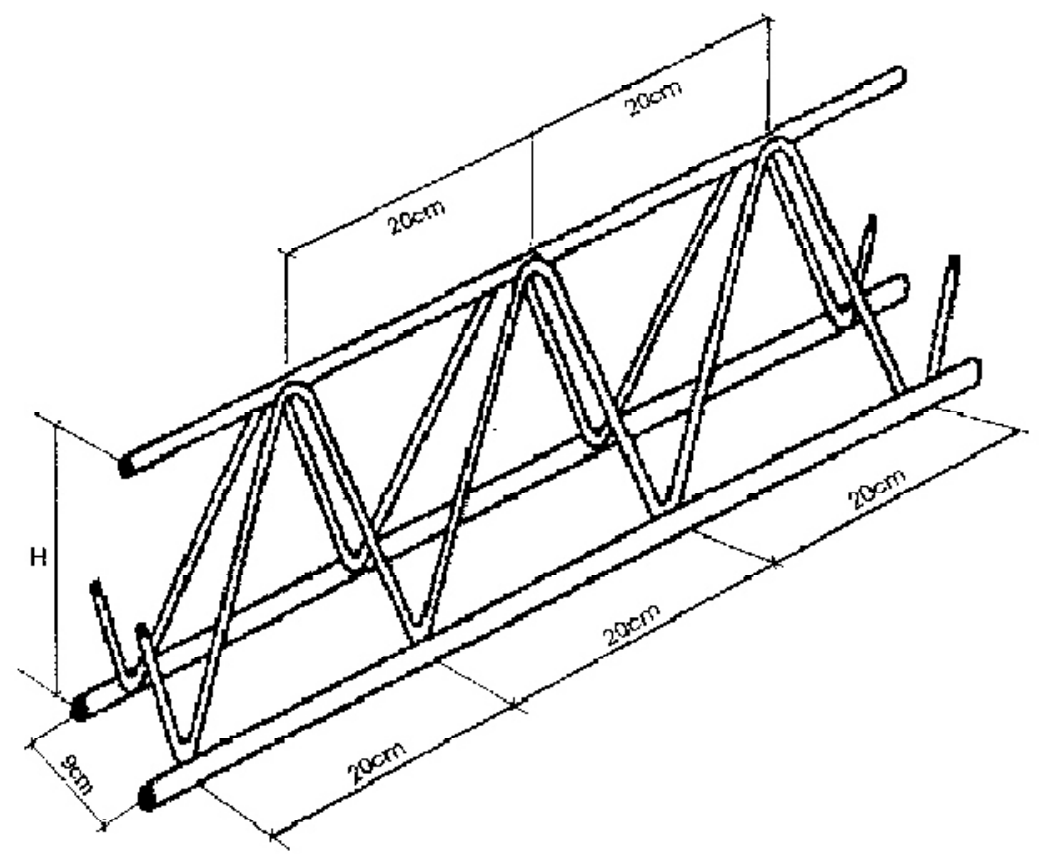

Figura 2.4 - Perspectiva de uma treliça (Manual de Fabricação das lajes PUMA, 2003) 


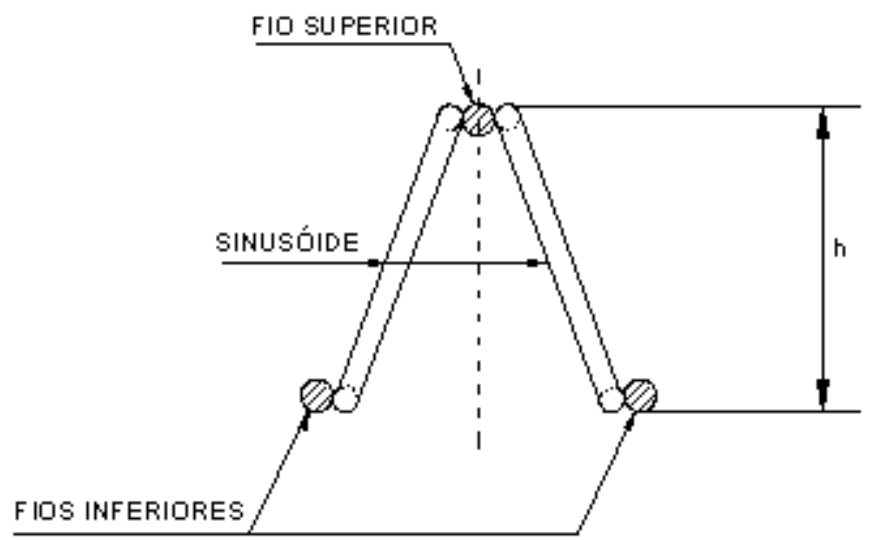

Figura 2.5 - Corte típico de uma treliça

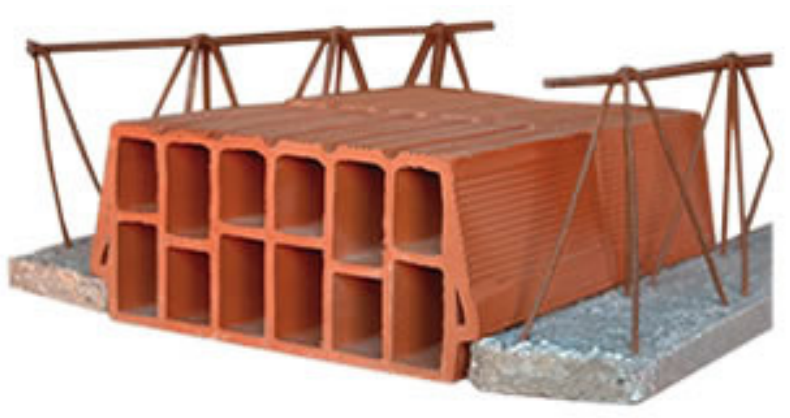

Figura 2.6 - Foto do conjunto vigota treliçada e bloco cerâmico (http://www.ceramicakaspary.com.br/portal/laje_trelicada.php, 2012)

O processo de fabricação das vigotas com armação treliçada é simples é composto de várias etapas. O Manual de Fabricação das lajes PUMA (2003) ilustra com fotos todo o processo. As fôrmas devem ficar a no mínimo 40 a $60 \mathrm{~cm}$ do chão, segundo os fabricantes. São constituídas de chapas de aço dobradas em forma de calha com 3mm de espessura. Após a limpeza da fôrma, esta recebe uma camada de óleo antiaderente para evitar que o concreto grude na parede da fôrma e facilite na desmoldagem da base da vigota após a concretagem (figura 2.7). O concreto lançado é adensado em uma mesa vibratória. Para o concreto, pode ser utilizado o cimento do tipo ARI, de alta 
resistência inicial, que proporciona uma resistência à compressão mais rápida, tornando mais rápido o envio das vigotas para a obra.

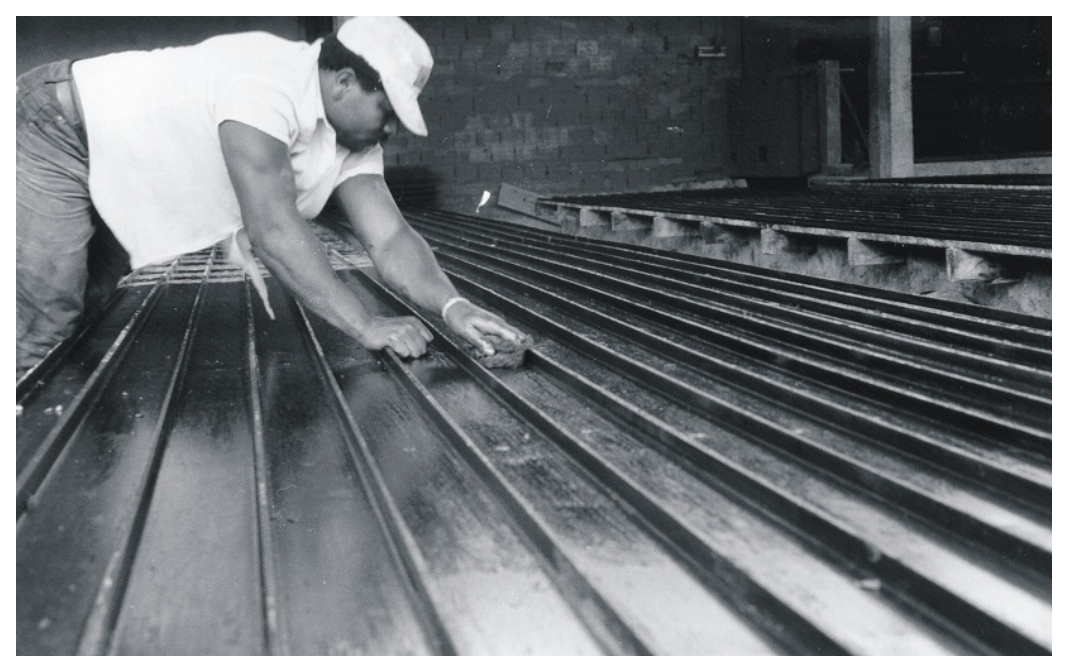

Figura 2.7 - Fôrma para vigota recebendo óleo anti-aderente ( Manual de Fabricação das lajes PUMA, 2003)

Um ponto importante é a necessidade da cura do concreto. Este processo impede a evaporação da água e evita o aparecimento de fissuras no elemento estrutural. Ela envolve uma combinação de fatores como tempo, umidade e temperatura que devem ser estudadas para garantir o fornecimento de um produto com qualidade para a obra.

\subsection{ANÁLISE ESTRUTURAL}

As lajes pré-fabricadas podem ser unidirecionais ou bidirecionais. As unidirecionais são formadas por nervuras principais longitudinais em uma única direção. Podem ser dispostas nervuras transversais perpendiculares às nervuras principais. Já as bidirecionais são constituídas de nervuras principais nas duas direções. 


\subsubsection{Comportamento unidirecional $\mathrm{x}$ bidirecional}

Droppa Jr. (1999) analisou lajes nervuradas formadas por vigotas treliçadas pré-moldadas com duas alturas e considerando dois tipos de lajes: unidirecional e bidirecional. Foram comparados os deslocamentos obtidos pelo modelo de viga para com o modelo de grelha, segundo análise não-linear. Os resultados mostraram que os deslocamentos obtidos com o modelo de grelha foram muito próximos ao modelo de viga. Isso demonstra que este último método é adequado o suficiente para aplicações práticas. Constataram-se, para a laje bidirecional, que os deslocamentos foram menores quando foi aplicada a análise com o modelo de grelha e altura de laje maior. Por fim, Droppa Jr. comprovou que utilizar lajes bidirecionais para vão maiores é uma boa alternativa quando se tem lajes mais altas e com relação entre os vãos próximos a um.

Os vãos mais utilizados para estas lajes foram pesquisados por Avilla Junior (2009) em uma pesquisa de campo feita pelo Brasil. Constatou que para $50 \%$ dos projetistas entrevistados o vão máximo de $6 \mathrm{~m}$ é considerado competitivo para as lajes formadas por vigotas treliçadas. $O$ trabalho de Figueiredo Filho e Shiramizu (2011) mostra o cenário atual do projeto, produção e execução dessas lajes. E corrobora o dado anterior através de uma pesquisa com fabricantes de vigotas treliçadas realizada na região de São Carlos, interior do estado de São Paulo. Os vãos mais solicitados pelos clientes estão entre $3 \mathrm{~m}$ e $6 \mathrm{~m}$ ( $50 \%$ do total), com uma tendência, segundo Figueiredo Filho e Shiramizu (2011), para a comercialização de vigotas que atendam vãos maiores.

\subsubsection{Vigas de borda}

Buiate e Lima (2005) realizaram um estudo, através de uma análise numérica, e compararam o comportamento de lajes formadas por vigotas com armação treliçada e sua interação com vigas de borda. Foi analisado também o comportamento da laje após o maciçamento de regiões próximas ao apoio. Concluiu-se que houve uma melhora na capacidade de vinculação das nervuras, além de contribuir, de forma expressiva, na diminuição da flecha da laje e 
rotações relativas nas vigas de borda estudadas na análise. Para lajes de grandes vãos devem-se controlar as rotações das vigas de borda já que influenciam nos esforços solicitantes e deformações, e podem provocar patologias em elementos não estruturais apoiados sobre ela como uma parede de vedação, conforme Buiate e Lima (2005).

\subsubsection{Nervuras transversais em lajes unidirecionais}

Outro ponto que merece atenção são as nervuras transversais às vigotas em lajes unidirecionais. Não é possível executar nervuras transversais em lajes formadas por vigotas de concreto armado comum ou protendido. Devem-se utilizá-las apenas para as vigotas com armação treliçada. A NBR 6118:1980 recomendava para lajes nervuradas moldadas "in loco" a adoção de uma nervura de travamento para vãos de 4,0m e duas nervuras para vãos de 6,0m. A norma atual não tece nenhum comentário a respeito. Em pesquisa feita através dos sítios eletrônicos dos fabricantes de laje, encontra-se, na maioria das vezes, a recomendação da NBR 6118:1980.

São executadas entre os elementos de enchimento, utilizando-o como fôrma para o concreto de capeamento moldado "in loco". Há no mercado blocos de poliestireno expandido com abas, próprios para esta finalidade (ver figura 2.8., de www.styrobia.com.br/construcao_civil.htm). Outra opção são as canaletas de plástico de alturas variáveis para utilizar com blocos cerâmicos ou de concreto ao invés das tradicionais travessas de madeira. Estas são colocadas entre os blocos e apresentam espaçadores integrados para as barras de aço e abas que impedem que o concreto lançado entre nos furos dos blocos (ver figuras 2.9 e 2.10 , de "www.faulim.com.br/canaleta").

Droppa Jr. (1999) analisou lajes unidirecionais com nervuras transversais e sua influência nos deslocamentos e distribuição de ações. Foram calculadas utilizando o modelo de viga e de grelha. A análise de resultados mostrou que a adoção de nervuras transversais contribui muito pouco na distribuição de esforços solicitantes e nos deslocamentos. É considerada apenas uma disposição construtiva. Porém, quando a laje está submetida a carregamentos 
diferentes (por exemplo, uma parede de alvenaria), estas nervuras diminuem o deslocamento relativo entre as vigotas. Vale ressaltar também sua importância em um eventual caso de colapso progressivo, ajudando no rearranjo dos esforços solicitantes e proporcionando uma maior rigidez à estrutura.

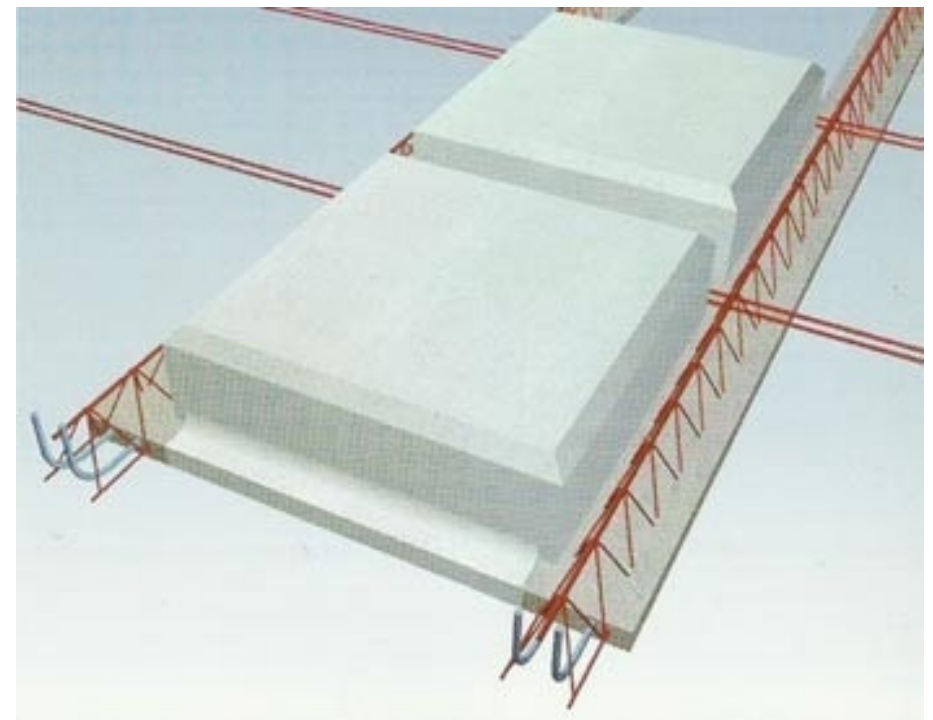

Figura 2.8 - Bloco em EPS com aba (www.styrobia.com.br/construcao_civil.htm)

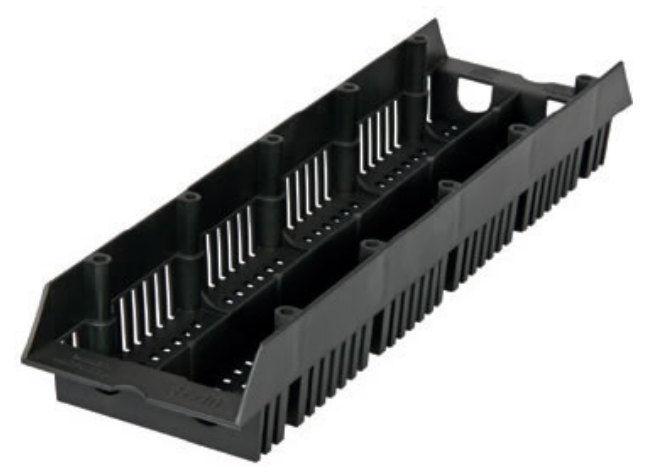

Figura 2.9 - Canaleta para nervuras transversais construtivas (www.faulim.com.br/canaleta) 


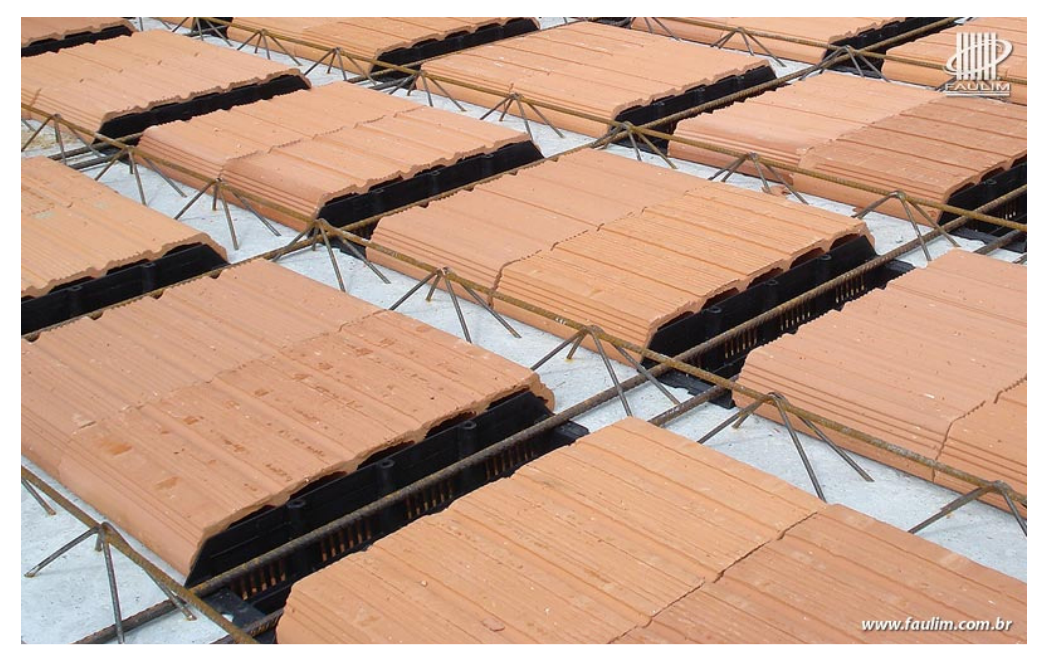

Figura 2.10 - Canaleta para nervuras transversais construtivas na laje (www.faulim.com.br/canaleta)

Avilla Jr. (2009) recomenda a utilização de nervuras transversais a cada $2 \mathrm{~m}$ e relata com base na sua experiência com lajes treliçadas $o$ aparecimento de fissuras paralelas às vigotas em lajes que apresentam geometrias com variação, como por exemplo, em forma de "T". A figura 2.11 extraída do trabalho de Avilla Jr. (2009), página 77, mostra a patologia por falta de nervura de travamento para as lajes que apresentam forma em "L".
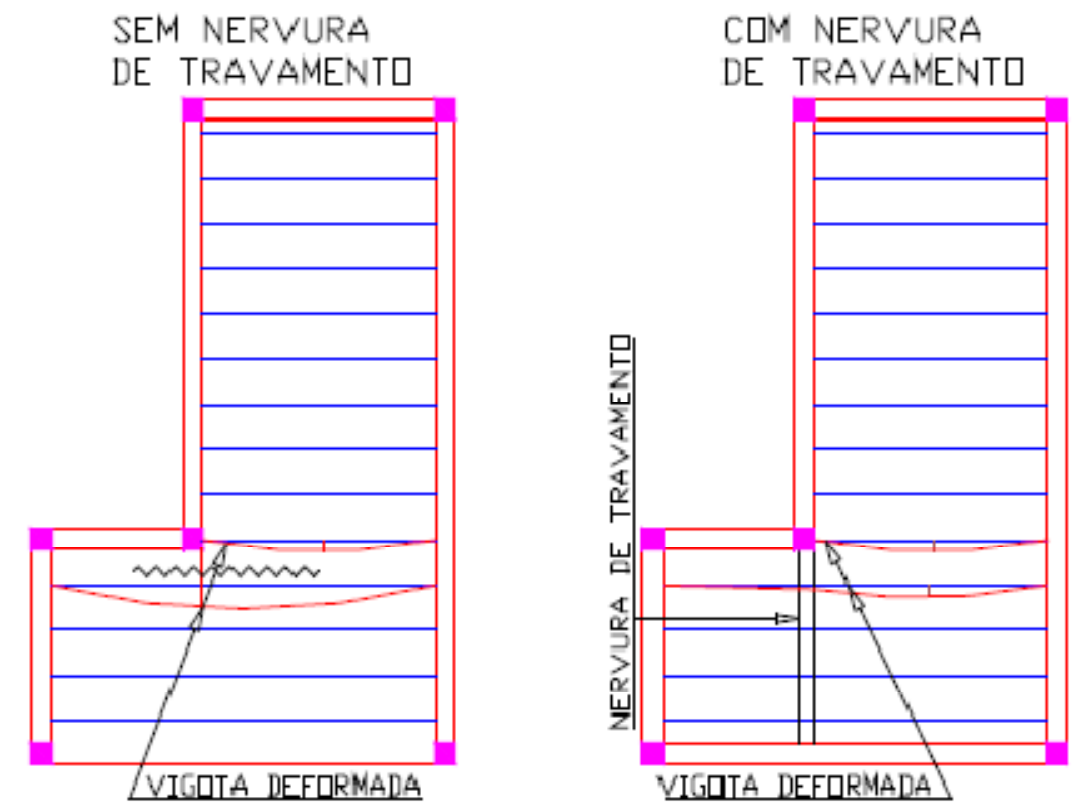

Figura 2.11 - Importância da nervura de travamento (AVILLA JR., 2009) 


\subsubsection{Nervuras transversais em lajes bidirecionais}

Figueiredo Filho et al. (2005) mostram a influência das nervuras transversais nas reações de apoio das lajes. E recomendam para lajes quadradas $(\lambda=1,0)$ que as vigas paralelas às vigotas recebam $37 \%$ das cargas totais atuantes. Para pavimentos com vãos diferentes (lajes retangulares) e $\lambda=1,5$, a recomendação é que $27 \%$ do carregamento total sejam transferidos para as vigas paralelas às vigotas. No entanto, os autores afirmam que os resultados não são definitivos e recomendam que toda a carga atuante "p" seja distribuída para as vigas perpendiculares às vigotas. $E$ a favor da segurança às outras vigas irão receber, portanto, 1,37 x "p" (lajes com $\lambda=1,0$ ) e 1,27 x "p" (lajes $\operatorname{com} \lambda=1,5)$.

Medrano e Figueiredo Filho (2006) estudaram a influência de nervuras transversais na distribuição do carregamento nas vigas de contorno em lajes bidirecionais. A adoção das nervuras proporcionou um comportamento do pavimento próximo ao de placa, mesmo com um número pequeno de nervuras. O enrijecimento e fissuração das vigas de contorno, neste estudo, não interferiram nos resultados.

\subsubsection{Análise não-linear}

Para estruturas de concreto armado em serviço o momento de fissuração é aquele que separa o estádio I do estádio II. As seções que apresentam momentos fletores maiores que o de fissuração estão trabalhando no estádio II. As lajes formadas por vigotas treliçadas pré-moldadas apresentam características favoráveis para que este momento de fissuração seja pequeno. Entre eles estão o formato da seção em "T" e o pequeno momento de inércia da seção bruta de concreto. A equação 2.1 possibilita o cálculo do momento de fissuração, de acordo com o item 17.3.1 da NBR 6118:2003.

$$
M_{r}=\frac{\propto \cdot f_{c t} \cdot I_{c}}{y_{t}}
$$


sendo $\alpha=1,2$ para seções T ou duplo T;

$\alpha=1,5$ para seções retangulares ( $\alpha$ é o fator que correlaciona aproximadamente a resistência à tração na flexão com a resistência à tração direta);

$y_{t}=$ distância do centro de gravidade da seção à fibra mais tracionada;

$I_{C}=$ momento de inércia da seção bruta de concreto;

$f_{c t}=$ resistência à tração direta do concreto (em MPa), utilizar $\mathrm{f}_{\text {ctk,inf }}$ neste caso.

Dessa forma, uma mesma peça, em serviço, pode estar trabalhando nos estádios I e II. Carvalho (1994) mostra a análise não-linear de pavimentos de edifícios de concreto através da analogia de grelha. Levou-se em conta a fissuração devida à flexão e à torção, além do efeito da fluência nos deslocamentos. O carregamento total é subdividido em incrementos de carga. Conclui que a fissuração aumenta o estado de deformação da estrutura e causa variações pequenas nos valores de momento fletor.

Uma das técnicas para resolver um problema não-linear é a do carregamento incremental, utilizada por Carvalho (1994). E consiste pela soma de " $n$ " etapas de carga, sendo que em cada uma a rigidez é corrigida. E também apresenta linearidade entre esforços e deslocamentos em cada etapa de carga.

É possível realizar um cálculo manual das flechas levando em conta que parte da laje está além do momento de fissuração e outra parte apresenta valores abaixo deste limite. Dessa forma, Branson (1968) propôs um modelo que utiliza uma única inércia para todo o elemento em análise, mesmo sabendo que este apresenta trechos fissurados e não fissurados. O momento de inércia médio proposto por Branson considera de maneira aproximada a fissuração do concreto. A expressão geral do modelo de Branson é dada pela expressão 2.2.

$$
I_{m}=\left(\frac{M_{r}}{M_{a t}}\right)^{n} \cdot I_{I}+\left[1-\left(\frac{M_{r}}{M_{a t}}\right)^{n}\right] \cdot I_{I I}
$$


sendo $\quad I_{m}=$ momento de inércia da seção bruta de concreto;

$I_{l}=$ momento de inércia da peça no estádio I;

$I_{I I}=$ momento de inércia da peça no estádio II puro;

$M_{r}=$ momento de fissuração do concreto;

$M_{a t}=$ momento fletor atuante na seção crítica do vão considerado;

$n=$ índice de valor igual a 4 para análise feita em uma seção da peça; e igual a 3 para análise da peça ao longo do seu comprimento.

Santini et al. (2004) realiza um exemplo prático utilizando os Sistemas TQS, programa para cálculo de estruturas. Neste exemplo é empregada a técnica do carregamento incremental, considerando a fissuração e fluência do concreto, através de uma análise linear e não-linear.

O exemplo consistia em analisar duas lajes pré-moldadas contíguas. Para tanto foram elaborados três casos: lajes simplesmente apoiadas, lajes com continuidade e lajes com região maciça de concreto no apoio central e continuidade. Para todos os casos, os dados são: lajes apoiadas sobre vigas de grande rigidez, concreto estrutural com $\mathrm{f}_{\mathrm{ck}}=20 \mathrm{MPa}$, sobrecarga de utilização com $q=1,50 \mathrm{kN} / \mathrm{m}^{2}$, elemento de enchimento com blocos cerâmicos, intereixo de $43 \mathrm{~cm}$, incrementos de carga $n=20$ (SANTINI et al., 2004).

Por fim, os resultados obtidos para cada caso analisado pelas formas linear e não linear foram resumidos na tabela 2.1.

Tabela 2.1 - Valores das flechas para tramo de 6m (SANTINI et al., 2004)

\begin{tabular}{l|c|c}
\hline \multirow{2}{*}{ CASOS } & ANÁLISE LINEAR & ANÁLISE NÃO-LINEAR \\
\cline { 2 - 3 } & Flecha $(\mathrm{cm})$ & Flecha $(\mathrm{cm})$ \\
\hline Simplesmente apoiadas & 2,69 & 6,84 \\
\hline Com continuidade & 1,70 & 1,97 \\
\hline $\begin{array}{l}\text { Com região maciça de } \\
\text { concreto no apoio central e } \\
\text { contínua }\end{array}$ & 1,70 & 1,33 \\
\hline
\end{tabular}




\subsection{DIMENSIONAMENTO}

Para que o projeto esteja de acordo com as normas vigentes é necessário verificar os estados limites de serviço e estados limites últimos do elemento estrutural.

\subsubsection{Estados Limites de Serviço}

As normas brasileiras de laje pré-fabricada NBR 14859-1:2002 e NBR 14859-2:2002 não apresentam procedimentos de cálculo a respeito de flechas imediatas ou diferidas no tempo de lajes formadas por vigotas pré-moldadas. Dessa forma, deve-se remeter à NBR 6118:2003 para efetuar tal cálculo.

Dentre os estados limites de serviço prescritos na NBR 6118 (2003) podese destacar: o estado limite de formação de fissuras (ELS-F), estado limite de abertura das fissuras (ELS-W), estado limite de vibrações excessivas (ELS-VE) e o estado limite de deformações excessivas (ELS-DEF). Com relação a este último, utiliza-se a combinação quase-permanente de ações, na qual todas as ações variáveis sofrem a mesma redução, afetadas pelo coeficiente de ponderação $\Psi_{2}$, dispostos na tabela 2.2 e extraída da NBR 6118:2003.

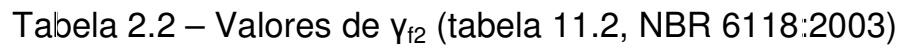

\begin{tabular}{|c|c|c|c|c|}
\hline \multirow{2}{*}{\multicolumn{2}{|c|}{ Ações }} & \multicolumn{3}{|c|}{$\gamma_{12}$} \\
\hline & & \multirow{2}{*}{$\psi$} & \multirow{2}{*}{$\psi_{1}{ }^{1)}$} & \multirow{2}{*}{$\begin{array}{l}\psi_{2} \\
0,3\end{array}$} \\
\hline \multirow{3}{*}{$\begin{array}{c}\text { Cargas } \\
\text { acidentais de } \\
\text { edifícios }\end{array}$} & $\begin{array}{l}\text { Locais em que não há predominância de } \\
\text { pesos de equipamentos que permanecem } \\
\text { fixos por longos períodos de tempo, nem de } \\
\text { elevadas concentrações de pessoas }\end{array}$ & & & \\
\hline & $\begin{array}{l}\text { Locais em que há predominância de pesos } \\
\text { de equipamentos que permanecem fixos por } \\
\text { longos períodos de tempo, ou de elevada } \\
\text { concentração de pessoas }\end{array}$ & 0,7 & 0,6 & 0,4 \\
\hline & Biblioteca, arquivos, oficinas e garagens & 0,8 & 0,7 & 0,6 \\
\hline Vento & $\begin{array}{l}\text { Pressão dinâmica do vento nas estruturas } \\
\text { em geral }\end{array}$ & 0,6 & 0,3 & 0 \\
\hline Temperatura & $\begin{array}{l}\text { Variações uniformes de temperatura em } \\
\text { relação à média anual local }\end{array}$ & 0,6 & 0,5 & 0,3 \\
\hline \multicolumn{5}{|c|}{$\begin{array}{l}\text { 1) Para os valores de } \psi_{1} \text { relativos às pontes e principalmente aos problemas de fadiga, ver seção } 23 \text {. } \\
{ }^{2)} \text { Edifícios residenciais. } \\
{ }^{3)} \text { Edifícios comerciais, de escritórios, estações e edifícios públicos. }\end{array}$} \\
\hline
\end{tabular}




\subsubsection{Estado Limite de Deformações Excessivas (ELS-DEF)}

A análise do ELS-DEF, segundo o item 17.3.2 da NBR 6118:2003: "(...) deve ser realizada através de modelos que considerem a rigidez efetiva das seções do elemento estrutural, ou seja, levem em consideração a presença da armadura, a existência de fissuras no concreto ao longo dessa armadura e as deformações diferidas no tempo".

A flecha total na laje é a soma das parcelas da flecha imediata e da flecha diferida ao longo do tempo (cargas de longa duração em função da fluência). $\mathrm{Na}$ primeira, utiliza-se a expressão de rigidez equivalente proposto por BRANSON (1968) e a outra é avaliada através da multiplicação da flecha imediata por um coeficiente denominado $\alpha_{f}$. É considerada mais crítica quando se leva em conta os efeitos reológicos do concreto como retração e fissuração.

Carvalho et al. (2000) mostram que a escolha da altura da laje está determinada em função da verificação da deformação excessiva, na maioria dos casos, e alerta que as tabelas para cálculo de vigotas treliçadas são inadequadas. Além disso, sugerem a construção de tabelas adicionais que indique qual a contraflecha a ser adotada em cada caso. A contraflecha, ainda segundo Carvalho et al. (2000), é importante pois ajuda a aumentar os vãos possíveis de serem vencidos. Porém, deve-se calcular com precisão a flecha imediata para sugerir uma contraflecha adequada, que não provoque um arqueamento da laje.

Um estudo teórico-experimental desenvolvido por Merlin et al. (2005) mostra que as flechas obtidas em ensaios experimentais realizados ao longo do tempo em lajes pré-moldadas com armação treliçada não são corroboradas quando comparadas com valores de modelos teóricos. Neste trabalho, utilizouse um modelo mais refinado através de elementos finitos e os resultados foram condizentes com os ensaios experimentais. A contribuição do concreto tracionado entre fissuras (em inglês, "tension stiffening") é considerada pelo modelo. Além disso, quando comparado com o modelo da NBR 6118:2003, que utiliza o coeficiente $\alpha_{F}$, as flechas ficaram subestimadas. Já o modelo da NBR 6118:2003 para peças não-fissuradas representou melhor o comportamento da 
laje, mostrando que o coeficiente de fluência expressa bem o modelo real, ficando $15 \%$ a favor da segurança.

Kataoka (2005) realizou experimentos com protótipos de lajes formadas por vigotas de concreto e conclui que o modelo da NBR 6118:2003 através do coeficiente $\alpha_{f}$ subestima os valores experimentais de flechas obtidos pela autora.

Merlin (2006) analisa as flechas diferidas em lajes pré-moldadas formadas por vigotas com armação treliçada, composta por elementos de enchimento de poliestireno expandido (EPS) e uma capa de concreto moldado no local. Foram analisadas lajes com intereixo de $49 \mathrm{~cm}$ e altura total variando de 12 a $30 \mathrm{~cm}$, e conseqüentemente, variando as treliças eletrossoldadas de acordo com altura utilizada. A figura 2.12 mostra as seções utilizadas nas análises.
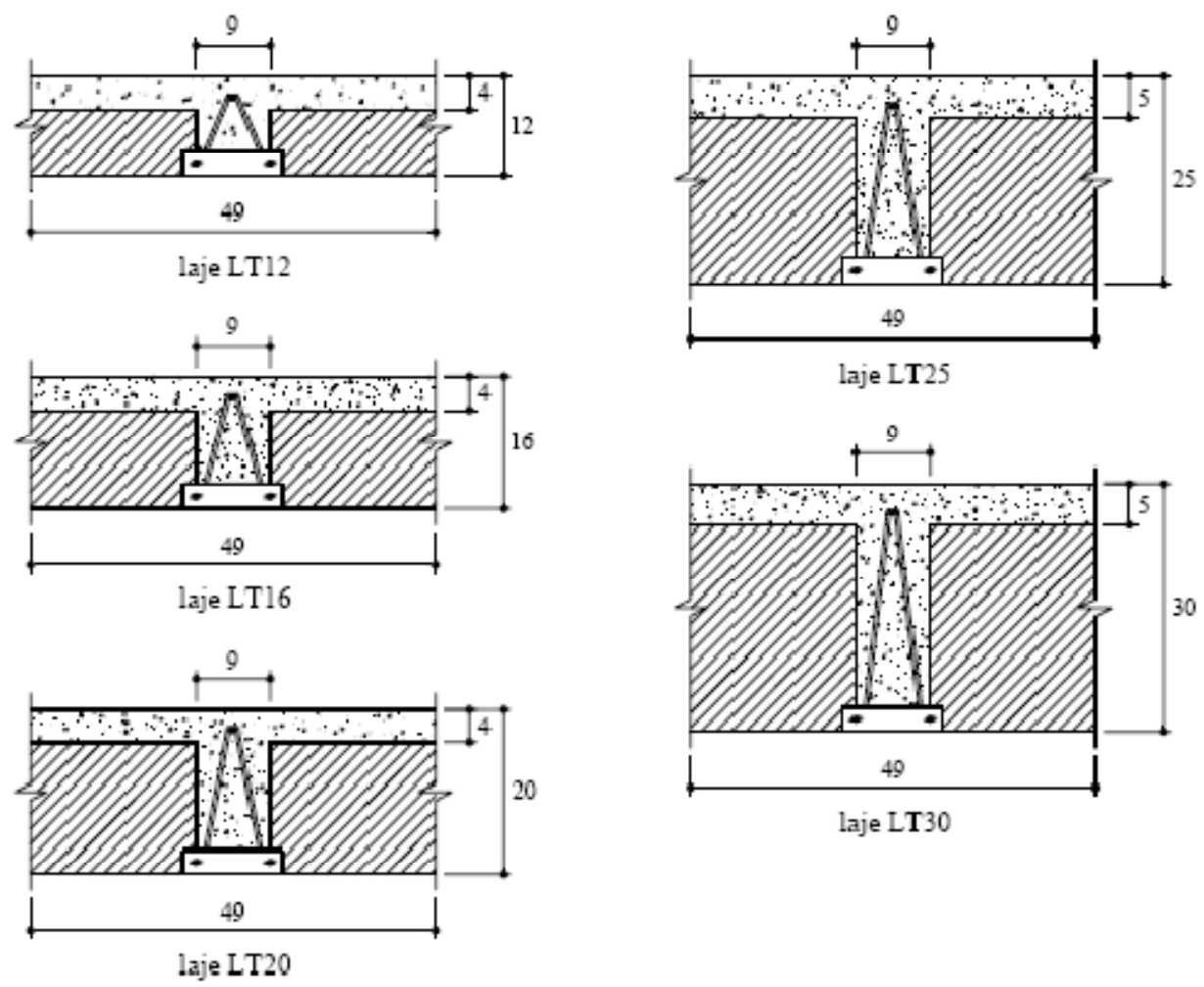

Figura 2.12 - Seções transversais das lajes, em cm (figura 5.4, MERLIN, 2006)

Foi feita uma análise preliminar para avaliar quais parâmetros afetam mais o coeficiente multiplicador a das flechas. Variou-se um a um os parâmetros, que são: carga acidental, resistência característica à compressão do concreto da vigota, resistência característica à compressão do concreto da capa, idade da 
concretagem da capa, intervalo de tempo entre a concretagem da capa e a retirada do escoramento, umidade relativa e temperatura ambiente.

Por fim, Merlin (2006) conclui que a umidade relativa, a temperatura ambiente e o tempo em que a laje fica escorada são os parâmetros que mais influenciaram no valor do coeficiente multiplicador $\alpha$. Posteriormente, com uma análise determinística e probabilística, encontrou-se um coeficiente $\alpha_{u, t}$, que expressa a influência da umidade relativa e temperatura ambiente. Este fator multiplicado pelo coeficiente multiplicador básico $\alpha_{\text {básico fornece a flecha }}$ instantânea, conforme expressão 2.3, para avaliação da flecha diferida de lajes pré-moldadas formadas por vigotas com armação treliçada.

$$
\alpha=\alpha_{\text {básico }} \cdot \alpha_{U, T}
$$

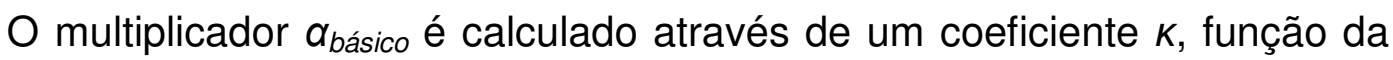
armadura, carregamento, altura e vão da laje. Merlin (2006) variou tais parâmetros e manteve constante a temperatura ambiente em $2^{\circ} \mathrm{C}$ e a umidade relativa em $60 \%$. A expressão 2.4 indica o seu cálculo e também do coeficiente $\mathrm{K}$ (expressão 2.5).

$$
\alpha_{\text {básico }}=3,73 \cdot \kappa+0,18
$$

com:

$$
\kappa=\frac{A_{s} \cdot h^{2,05}}{p^{1,5} \cdot l^{3}} \cdot 10^{3}
$$

sendo: $A_{s}=$ área de armadura $\left(\mathrm{cm}^{2}\right)$;

$h=$ altura da laje $(\mathrm{cm})$;

$p=$ carregamento aplicado $(\mathrm{kN} / \mathrm{m})$;

$I=$ vão da laje $(\mathrm{m})$.

As expressões 2.2 a 2.4, segundo Merlin (2006) são válidas para lajes biapoiadas. Para as lajes contínuas, podem-se utilizar as expressões desde que 
a intensidade da fissuração destas seja compatível com a da laje biapoiada, tanto no apoio quanto no vão.

O coeficiente $\alpha_{u, t}$, obtido pela análise determinística é dado pela expressão 2.6 e pela análise probabilística, com $85 \%$ de probabilidade, é dado pela expressão 2.7 .

$$
\begin{aligned}
& \alpha_{u, t},=8,8 \cdot 10^{-3} \cdot T-0,012 \cdot U+1,43 \\
& \alpha_{u, t}=0,016 \cdot T-0,012 \cdot U+1,84
\end{aligned}
$$

sendo: $U$ = umidade relativa do ambiente (em \%);

$\mathrm{T}=$ temperatura média do ambiente $\left(\mathrm{em}^{\circ} \mathrm{C}\right)$.

Merlin (2006) realizou exemplos para determinação dos coeficientes multiplicadores para a flecha imediata em lajes com $12 \mathrm{~cm}, 16 \mathrm{~cm}$ e $20 \mathrm{~cm}$. Na tabela resumo 2.3, apresenta-se também o fator $\alpha_{f}$ e o coeficiente de fluência $\alpha$ recomendados pela NBR 6118:2003, considerando idade de aplicação da carga de 21 dias.

Tabela 2.3 - Coeficientes obtidos por MERLIN (2006) para os exemplos realizados

\begin{tabular}{cccccc}
\hline \multirow{2}{*}{ laje } & $\begin{array}{c}\mathbf{q} \\
\left(\mathbf{k N} / \mathbf{m}^{\mathbf{2}}\right)\end{array}$ & $\begin{array}{c}\boldsymbol{\alpha} \\
\text { análise } \\
\text { determinística }\end{array}$ & $\begin{array}{c}\boldsymbol{\alpha} \\
\text { análise } \\
\text { probabilística }\end{array}$ & $\begin{array}{c}\boldsymbol{\alpha}_{\mathbf{f}} \\
\text { (NBR 6118) }\end{array}$ & $\begin{array}{c}\boldsymbol{\varphi} \\
\text { (NBR 6118) }\end{array}$ \\
\hline \multirow{3}{*}{ LT12 } & 2,0 & 0,95 & 1,43 & 1,40 & 3,05 \\
\cline { 2 - 6 } & 3,5 & 1,26 & 1,89 & 1,40 & 3,05 \\
\cline { 2 - 6 } & 5,0 & 1,46 & 2,19 & 1,40 & 3,05 \\
\hline \multirow{2}{*}{ LT16 } & 2,0 & 0,92 & 1,34 & 1,40 & 3,52 \\
\cline { 2 - 6 } & 3,5 & 1,32 & 1,92 & 1,40 & 3,52 \\
\hline \multirow{2}{*}{ LT20 } & 5,0 & 1,53 & 2,23 & 1,40 & 3,52 \\
\hline
\end{tabular}

Os valores desta tabela mostram que os coeficientes multiplicadores da flecha imediata a obtidos através da análise probabilística estão acima do 
recomendado pela NBR 6118:2003. Guarda et al. (2006) também aponta a alteração quando compara os deslocamentos da norma com os obtidos pelo programa ANPAV. Os coeficientes relacionados à duração do carregamento e a taxa de compressão subestimam os deslocamentos. Assim, afirmam: "...Diante disto, parece aconselhável uma alteração do procedimento proposto pela NBR 6118 (2003) para o cálculo dos deslocamentos diferidos de lajes". (Guarda et al., 2006, pág. 13).

\subsubsection{Estado Limite de Vibrações Excessivas (ELS-VE)}

Com relação ao ELS-VE, Chen (1999) afirma que do ponto de vista do projeto estrutural a aceitabilidade da vibração de pavimentos é um tópico muito importante na fase de dimensionamento, além das verificações de resistência e segurança.

Almeida et al. (2005) enfatiza ainda que a esbeltez e leveza presente em elementos pré-moldados, do ponto de vista da vibração, trazem algumas consequêencias à estrutura, tais como: não-linearidade geométrica mais pronunciada, aumento da fissuração e, conseqüentemente, não-linearidade física mais evidente, com aumento da sensibilidade às vibrações.

Ensaios dinâmicos de caráter não-destrutivo também apresentam a vantagem de fornecer informações integradas e globais da estrutura a respeito da rigidez e, além disso, podem ser repetidos e comparados ao longo do tempo.

Algumas propriedades dinâmicas são muito importantes. Destacam-se a freqüência natural e o amortecimento. Segundo Almeida (2005), freqüência natural é o parâmetro modal mais importante da estrutura e representa a taxa de oscilação livre, depois de terminada a força que provocou o seu movimento. Para Mast (2001) ela é importante porque determina como será a resposta da estrutura quando submetida a esforços que geram a vibração. $O$ corpo humano é mais sensível a freqüências entre 4 a $8 \mathrm{~Hz}$. Segundo Mast (2001), esta variação da freqüência natural é comumente encontrada para os pavimentos em geral. 
Quanto mais flexível for o piso, menor a sua freqüência natural. A freqüência natural de um sistema de 1 grau de liberdade é dada pela equação abaixo.

$$
f=\frac{1}{2 . \pi} \cdot \sqrt{\frac{K}{M}}
$$

sendo: $f=$ freqüência natural $(\mathrm{Hz})$;

$K=$ rigidez do sistema $(\mathrm{N} / \mathrm{m})$;

$M=$ massa do sistema $(\mathrm{kg})$;

Analisando a expressão 2.8 observa-se que a freqüência é inversamente proporcional à massa e diretamente proporcional à rigidez. Dessa forma, há influência de propriedades da estrutura como módulo de elasticidade do material, comprimento do vão, momento de inércia e vinculação.

Um sistema estrutural possui várias freqüências naturais e sua quantidade está determinada pelo número de graus de liberdade. Cada uma obedece à expressão 2.8. Na maioria das vezes a freqüência fundamental é a primeira e mais importante das freqüências, além de apresentar o valor numérico mais baixo entre elas.

Quando a freqüência natural se aproxima ou se torna igual à freqüência da fonte de excitação, diz-se que está próxima ou na ressonância. Com isso, existem algumas soluções para diminuir esta freqüência natural e impedir deformações excessivas na estrutura. A mais comum e discutida é a aquela que diz respeito ao ajuste de freqüências. Almeida et al. (2004) indica que através de uma análise simplificada, ou até mesmo refinada, detecta-se a freqüência natural do sistema $\left(f_{n}\right)$, comparando-o à freqüência natural mínima necessária $\left(f_{m i ́ n}\right)$, associada à excitação esperada. Quando $f_{n} \geq f_{m i ́ n}$, a estrutura não apresenta o risco de entrar em ressonância ou de apresentar vibrações excessivas. Por outro lado, quando $f_{n}<f_{\text {mín }}$ é necessário alterar as características estruturais de rigidez.

Conforme Almeida et al. (2004), para relacionar a rigidez da estrutura com o carregamento aplicado e vão é necessário calcular freqüências e modos de 
vibração, que para uma estrutura discretizada por nós, é formulada pela seguinte expressão 2.9:

$$
([\mathrm{K}]-\{\lambda\}[\mathrm{M}])[\mathrm{x}]=\{0\}
$$

sendo : $[\mathrm{K}]=$ matriz de rigidez da estrutura;

$[\mathrm{M}]=$ matriz de massa da estrutura;

$\{\lambda\}=$ vetor dos autovalores, as freqüências naturais;

$[\mathrm{x}]=$ matriz dos autovalores, os modos de vibração.

A partir da resolução deste problema, através da técnica dos Elementos Finitos, por exemplo, resulta em equações para problemas típicos de lajes. Quando se tem uma viga simplesmente apoiada, com carregamento uniforme ao longo do seu comprimento, a expressão para encontrar a freqüência natural resulta: (ALMEIDA et al.,2004):

$$
f_{n}=\frac{\pi}{2} \cdot \sqrt{\frac{E \cdot I \cdot g}{w \cdot L^{4}}}
$$

sendo : $f_{n}=$ freqüência natural de vibração fundamental $(\mathrm{Hz})$;

$\mathrm{E}=$ módulo de elasticidade $\left(\mathrm{N} / \mathrm{m}^{2}\right)$;

$\mathrm{I}=$ momento de inércia da secção bruta $\left(\mathrm{m}^{4}\right)$;

$\mathrm{g}=$ aceleração da gravidade $\left(\mathrm{g}=9,81 \mathrm{~m} / \mathrm{s}^{2}\right)$;

w = carga distribuída, permanente mais variável, por unidade de comprimento $(\mathrm{N} / \mathrm{m})$;

$\mathrm{L}=$ comprimento do vão $(\mathrm{m})$.

Almeida et al. (2004) acrescenta que os valores de "w" da expressão 2.10 não são os valores de cálculo. Murray et al.(1997) recomenda um valor para as cargas variáveis, apenas, de $0,50 \mathrm{kN} / \mathrm{m}^{2}$ para pisos de escritórios, $0,25 \mathrm{kN} / \mathrm{m}^{2}$ para pisos de residências e 0 ou próximo a zero para passarelas, piso de shoppings e ginásio. Estes valores menores de carga ou massa favorecem um projeto mais racional, pois aumenta o valor da freqüência natural. Mast (2001) 
adiciona que isso torna os problemas de vibração mais críticos, sendo assim, o motivo pelo qual se adota valores de cargas variáveis mais realistas.

Para outros tipos de vinculação, há a forma mais geral com a constante "R" representando as vinculações, conforme expressão 2.11. As constantes estão apresentadas na tabela 2.4 e são originadas, segundo Mast (2001), de expressões analíticas de cálculo de vibrações de sistemas contínuos.

$$
f_{n}=R \sqrt{\frac{E \cdot I \cdot g}{w \cdot L^{4}}}
$$

Tabela 2.4 - Constante "R" de acordo com a vinculação

\begin{tabular}{|c|c|}
\hline VIN & $\mathrm{R}$ \\
\hline गो & 1,57 \\
\hline & 2,45 \\
\hline & 0,56 \\
\hline & 3,56 \\
\hline
\end{tabular}

O módulo de elasticidade do concreto utilizado na expressão 2.11 referese ao módulo de elasticidade dinâmico. Pode ser adotado um aumento de $20 \%$ em relação ao módulo de elasticidade secante. Analisando a expressão 2.11 conclui-se que o aumento do módulo de elasticidade resulta em uma frequência natural maior e, conseqüentemente, em uma estrutura mais rígida.

No caso de pisos pré-moldados, a eficácia das ligações contribui na determinação da flexibilidade e, conseqüentemente, na determinação da 
freqüência natural. O grau de fissuração da peça também influencia o seu valor, pois com a evolução da formação das fissuras e aumento de suas aberturas, existe uma diminuição da freqüência natural fundamental (diminuição da rigidez "K"). Esta é a primeira e também a menor das freqüências. Por isso, torna-se a mais importante, podendo ocasionar problemas às estruturas civis. Mast (2001) recomenda que as freqüências naturais dos pisos não sejam menores que $3 \mathrm{~Hz}$, já que esta é a faixa principal relacionada à movimentos de pessoas, em atividades sincronizadas ou intencionais.

Outra propriedade importante no que diz respeito às vibrações excessivas é o amortecimento. Almeida (2005) o define como "a propriedade interna de dissipar energia pelo processo viscoso e atrito do sistema". Influencia na propagação do efeito vibratório e o intervalo de duração do movimento, após o término do estímulo. É de grande importância para o projeto, pois a percepção humana e a tolerância à vibração dependem de quanto tempo ela demora. $O$ amortecimento de um piso é altamente dependente de itens não-estruturais, como divisórias, coberturas, móveis etc. É uma propriedade de difícil e complexa mensuração.

No caso das lajes formadas por vigotas com armação treliçada, a definição do tipo de elemento de enchimento pode influenciar na verificação da vibração, já que quanto menor for o peso específico do material, menor será a freqüência natural da estrutura. Assim, é recomendável utilizar elementos de enchimento de blocos cerâmicos ou de concreto ou invés do bloco em EPS, apenas quando se analisa o aspecto das vibrações na laje.

Para uma laje de piso, as análises são feitas para diversos carregamentos que provocam vibração, e são agrupados em (ALMEIDA et al., 2004): (a) vibrações induzidas pelo caminhar; (b) vibrações induzidas por atividades rítmicas e aeróbicas.

\section{(a) Vibração induzida pelo caminhar}

Segundo MAST (2001), levando em conta os efeitos da ressonância da caminhada em um piso, uma formulação empírica indica a freqüência mínima, conforme a expressão 2.12 . 


$$
f_{\min }=2,86 \cdot \ln \left(\frac{F}{\zeta \cdot W_{e}}\right)
$$

sendo: $f_{\min }=$ freqüência natural fundamental mínima do sistema estrutural $(\mathrm{Hz})$;

$F=$ constante relacionada ao carregamento do piso (ver tabela 2.5);

$\zeta=$ taxa de amortecimento modal (ver tabela 2.5);

$W_{e}=$ peso efetivo, equivalente ao peso total da área do piso influenciada pelo carregamento concentrado $(\mathrm{kN})$.

Tabela 2.5 - Valores de F e $\zeta$ (MAST, 2001)

\begin{tabular}{l|c|c}
\multicolumn{1}{c|}{ Tipo de construção } & $\mathbf{F ~ ( k N )}$ & $\zeta$ \\
\hline & & $0,02^{\mathrm{a}}$ \\
Escritórios, residências, igrejas & 58 & $0,03^{\mathrm{b}}$ \\
& & $0,05^{\mathrm{c}}$ \\
\hline "Shopping centers" & 20 & 0,02 \\
\hline Passarelas & 8 & 0,01
\end{tabular}
a) pisos com poucos elementos estruturais e mobília, áreas abertas e igrejas
b) pisos com elementos não estruturais e mobília
c) pisos com divisórias inteiriças entre pisos

A resposta ao impacto causado pelos pés da pessoa ao caminhar sobre a laje depende da massa da estrutura. Tem-se então um peso efetivo We, resultado das cargas permanentes e sobrecargas da laje multiplicada pelo vão da laje, L, e uma largura B. Esta pode variar, e de acordo com Mast (2001), pode-se adotar o valor de B como:

- $B=L$, para lajes maciças e alveolares;

- B = 0,8.L, para painéis "duplo T" de 45,7cm com 7,62 de capa;

- $B=0,7$. L, para painéis "duplo T" de $81,3 \mathrm{~cm}$ com 7,62cm de capa; 
A figura 2.13 ilustra o cálculo do peso efetivo We para as lajes.

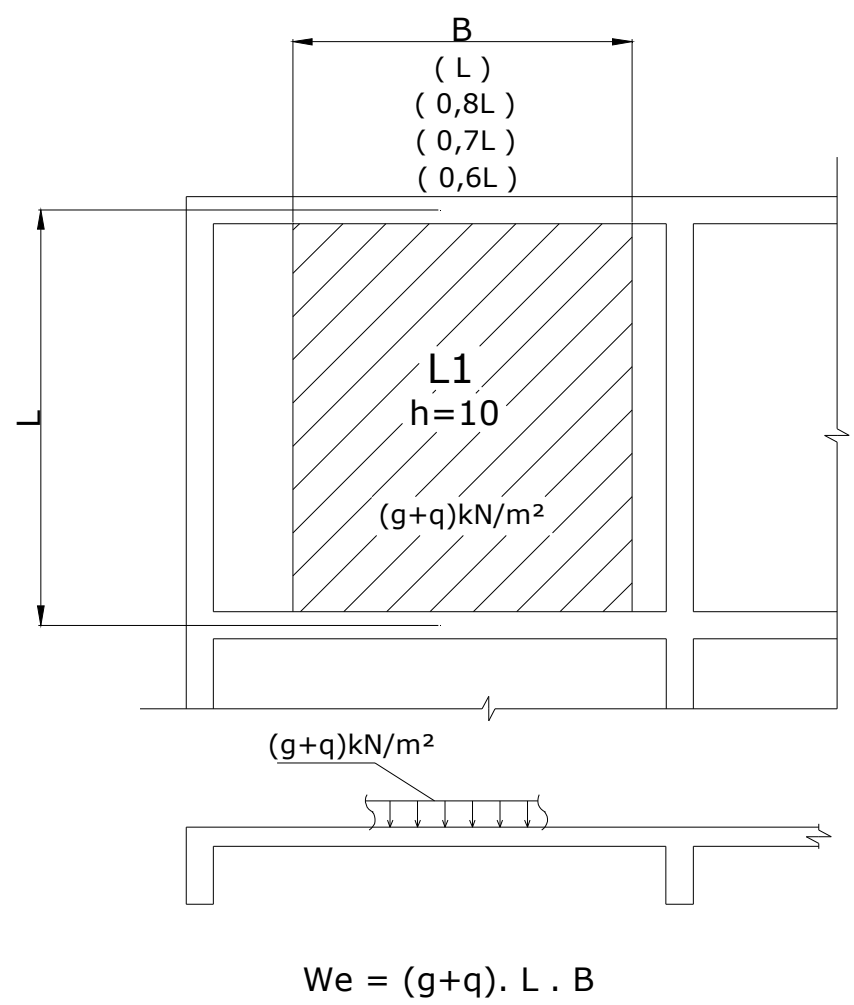

Figura 2.13 - Cálculo do peso efetivo We

\section{(b) Vibração induzida por atividades rítmicas e aeróbicas}

Segundo Mast (2001), festas como eventos musicais ou esportivos, geram vibração realizada repetidamente, por várias pessoas e sincronizadas, em conseqüência de um estímulo externo, como música, pulos de torcedores etc. Esta vibração em freqüência quase constante produz a atividade ritmada, com valores de força de excitação maiores que aquela produzida na caminhada.

Os três tipos de atividades que fazem parte desta situação são:

- dança: pisos de academia de dança ou salões de dança;

- concertos ou eventos esportivos: pisos de locais que abrigam shows musicais ou torcidas em geral;

- atividade aeróbica: pisos de academias de ginástica, clubes e quadras de escola. 
A verificação da freqüência mínima (expressão 2.13), neste caso, deve ser feita para cada uma das harmônicas a fim de evitar vibrações excessivas independentemente da situação.

$$
f_{\min }=f \cdot \sqrt{1+\frac{K}{a_{\max } / g} \cdot \frac{\alpha_{i} \cdot w_{p}}{w_{t}}}
$$

sendo: $f_{\min }=$ freqüência natural fundamental mínima do sistema estrutural $(\mathrm{Hz})$;

$f=$ freqüência da força de excitação, $\left(f=i \cdot f_{\text {excit }}\right),(\mathrm{Hz})$;

$i=$ número do harmônico da força de excitação (1, 2 ou 3), indicada na tabela 2.6.

$f_{\text {excit }}=$ freqüência básica da força de excitação

$k=$ constante adimensional que depende do tipo de atividade sobre 0 piso: 1,3 para dança, 1,7 para concertos ou eventos esportivos e 2,0 para atividade aeróbica;

$\alpha_{i}=$ coeficiente de ação dinâmica, dado pela tabela 2.6

$w_{p}=$ peso dos participantes, por área, distribuído uniformemente sobre 0 piso $\left(\mathrm{kN} / \mathrm{m}^{2}\right)$, especificado na tabela 2.6.

$\boldsymbol{W}_{T}=$ peso total, por unidade de área, distribuído uniformemente sobre o piso (peso dos participantes mais peso próprio do piso), $\left(\mathrm{kN} / \mathrm{m}^{2}\right)$;

$a_{\text {máx }} / g=$ razão da aceleração máxima pela aceleração devido à gravidade, com seus limites especificados na tabela 2.7.

Tabela 2.6 - Valores estimados dos coeficientes dinâmicos, de acordo com a finalidade (MURRAY et al., 1997)

\begin{tabular}{l|c|c|c} 
Atividade & $\begin{array}{c}\text { Frequência de } \\
\text { excitação }-\mathbf{f}_{\text {excit }}(\mathbf{H z})\end{array}$ & $\begin{array}{c}\text { Peso dos } \\
\text { participantes } \mathbf{w}_{\mathbf{p}} \\
\left(\mathbf{k N} / \mathbf{m}^{\mathbf{2}}\right)\end{array}$ & $\begin{array}{c}\text { Coeficiente } \\
\text { dinâmico }-\boldsymbol{\alpha}_{\mathbf{i}}\end{array}$ \\
\hline Dançar & 0,6 & 0,6 \\
\hline 10 harmônico & 1,5 a 3,0 & & \\
\hline $\begin{array}{l}\text { Concertos ou eventos } \\
\text { esportivos }\end{array}$ & \multicolumn{3}{|l}{} \\
\hline 10 harmônico & 1,5 a 3,0 & 1,5 & 0,25 \\
\hline 20 harmônico & 3,0 a 5,0 & 1,5 & 0,05 \\
\hline
\end{tabular}


Tabela 2.7 - Valores limites recomendáveis de aceleração para atividades rítmicas (MAST, 2001).

\begin{tabular}{l|c}
\multicolumn{1}{c|}{ Finalidade da construção } & Aceleração limite $-\mathbf{a}_{\text {máx }} / \mathbf{g}$ \\
\hline Escritório ou residência & 0,004 a 0,007 \\
\hline Dança & 0,015 a 0,025 \\
\hline Atividades rítmicas & 0,04 a 0,07
\end{tabular}

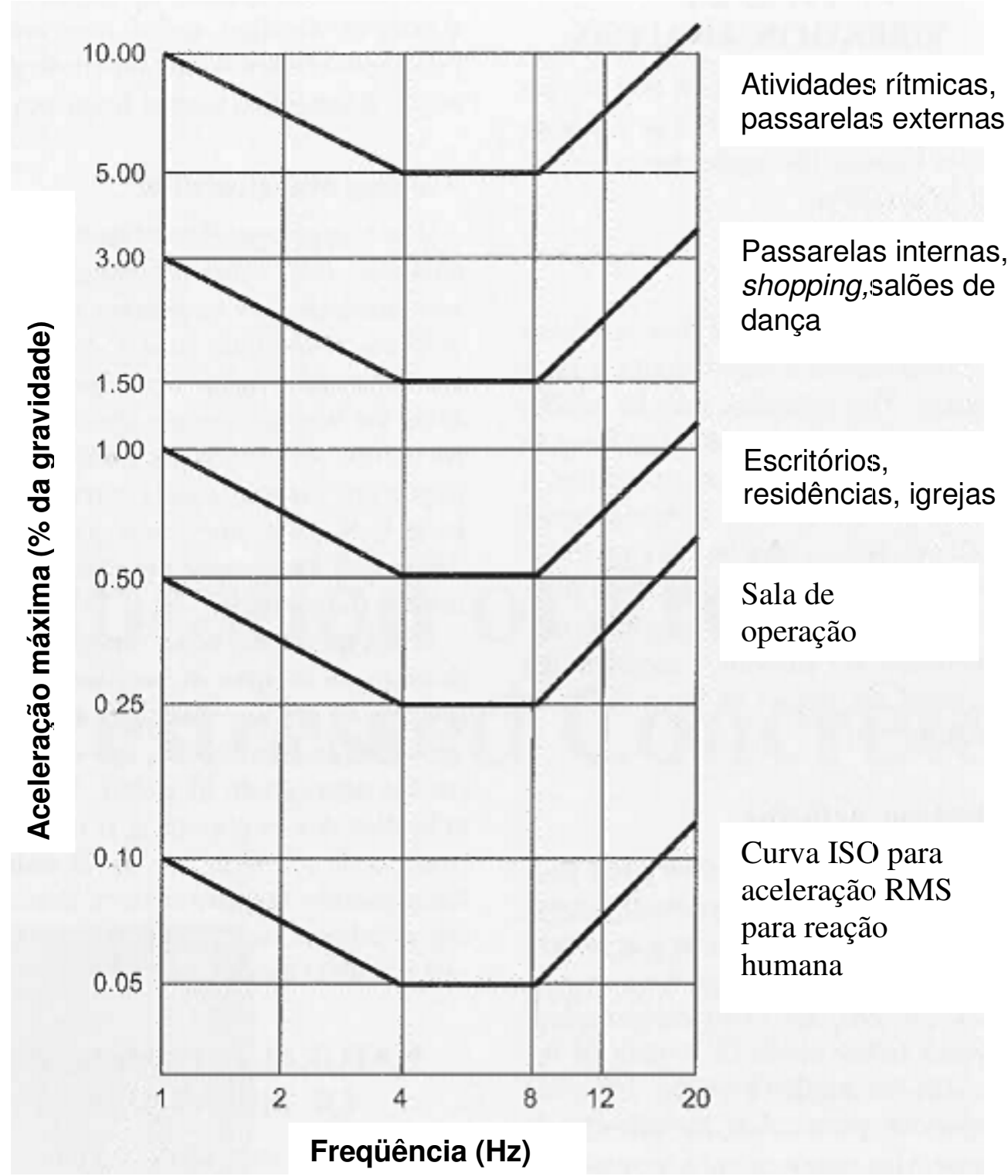

Figura 2.14 - Aceleração máxima aceitável para o conforto humano em diferentes ambientes, em função da freqüência (adaptado de MAST, 2001) 
O item 23.3 da NBR 6118:2003 trata especificamente do ELS-VE. Recomenda que se afaste o máximo possível a freqüência própria da estrutura (f) da freqüência natural da fonte excitadora, denominada freqüência crítica ( $f_{\text {crit }}$ ), em, no mínimo, 20\%. A tabela 2.8 a seguir, apresentada na NBR 6118:2003, mostra casos específicos de estruturas submetidas a vibrações pela ação de pessoas.

Tabela 2.8 - Freqüência crítica para alguns locais submetidos à vibração pela ação humana (NBR 6118:2003)

\begin{tabular}{l|c}
\multicolumn{1}{c|}{ Caso } & $\mathbf{f}_{\text {crit }} \mathbf{( H z )}$ \\
\hline Ginásio de esportes & 8,0 \\
\hline Salas de dança ou de concerto sem cadeiras fixas & 7,0 \\
\hline Escritórios & 3,0 a 4,0 \\
\hline Salas de concerto com cadeiras fixas & 3,4 \\
\hline Passarelas de pedestres ou ciclistas & 1,6 a 4,5
\end{tabular}

No trabalho de Almeida et al. (2004) foram feitas análises de estruturas de concreto pré-moldado usuais, segundo o tipo de excitação. Entre elas estão as lajes formadas por vigotas com armação treliçada. $O$ elemento de enchimento utilizado foi o bloco de EPS. Foram adotadas duas hipóteses: os vínculos são considerados apoio-apoio e não foi considerada a redução da inércia devido à fissuração. Nas análises, verificou-se que mesmo aumentando a espessura da laje, não há um aumento do vão máximo permitido. O tipo de excitação mais crítica foi a caminhada. Nesta análise específica, para efeito de comparação, a laje treliçada $L T 16$ resulta em um vão máximo de apenas $3 \mathrm{~m}$ para que não haja vibrações excessivas na laje, de acordo com a NBR 6118:2003.

Diogenes (2010) aponta que a análise dinâmica vem se tornando mais importante para projetos de estruturas, principalmente devido a alguns fatores, tais como: (a) obras que utilizam equipamentos e geram ações de natureza e proporções que não podem ser consideradas estáticas; (b) aprimoramento da arquitetura e procedimentos de cálculo que permitem melhor análise do comportamento dos sistemas estruturais mais deformáveis; (c) a globalização leva profissionais a regiões onde abalos sísmicos são fatores preponderantes no cálculo estrutural obrigando-o a entender as vibrações. 
O estudo da vibração em estruturas de concreto pré-moldado é algo mais complexo que apenas uma análise experimental com ensaios usuais. É preciso realizar, segundo DIOGENES (2010), pág. 36, “(...) técnicas complementares experimentais e computacionais, que consistem de ensaios dinâmicos de vibração livre ou forçada e subseqüente análise modal, possibilitam quantificar corretamente as ações e seus efeitos, verificar as solicitações na estrutura e a sua resposta, avaliar o conforto humano frente às vibrações, e determinar a integridade estrutural".

\subsubsection{ESTADO LIMITE ÚLTIMO}

O elemento estrutural pode atingir o Estado Limite Último de ruína quando o momento fletor atuante ou a força cortante atuante for maior que as resistências daquelas seções transversais. Os próximos itens discorrem sobre o dimensionamento das lajes quanto ao momento fletor e à força cortante.

\subsubsection{Momento fletor}

Quando atua um momento fletor positivo ou negativo, a seção transversal a ser considerada para resistir a estes esforços é diferente. Para o momento positivo há a largura da mesa de compressão colaborante, $b_{f}$, e a altura da linha neutra (L.N.) que está na zona comprimida, $x$. A seção geralmente apresenta forma de "T". É necessário conhecer a profundidade da linha neutra. Já para o momento negativo, a seção resistente à compressão é retangular, sendo $b_{w}$ a largura da nervura. As figuras 2.15 e 2.16 mostram as regiões hachuradas comprimidas das seções transversais. Não será apresentado aqui o equacionamento para encontrar 0 momento resistente da seção quando submetida ao momento fletor negativo ou positivo. O equacionamento completo, com o equilíbrio de momentos, resistências e compatibilidade de deformações, pode ser encontrado em livros de concreto armado para flexão simples, como por exemplo, Carvalho e Figueiredo Filho (2005) e Giongo (2007). 


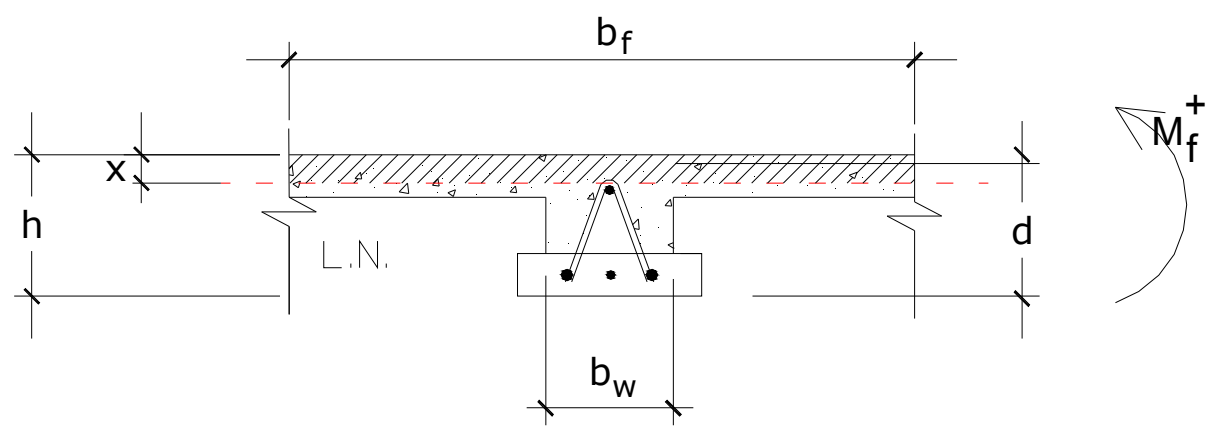

Figura 2.15 - Seção "T" para momento positivo

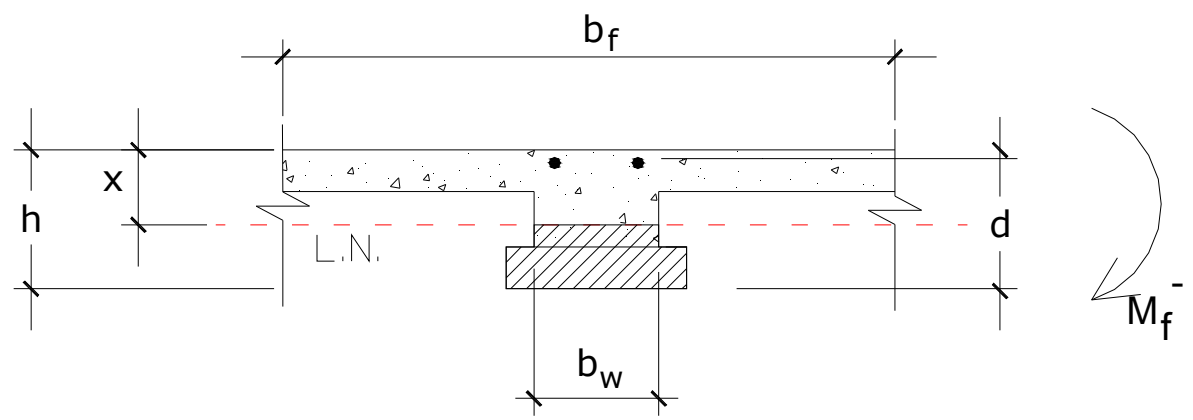

Figura 2.16 - Seção retangular para momento negativo

Para determinar a largura colaborante $b_{f}$, a NBR 6118:2003, no item 14.6.2.2., mostra que $b_{f}$ deve ser dada pela largura da nervura $b_{w}$ acrescida de $10 \%$ da distância "a" entre os pontos de momento fletor nulo, para cada lado da nervura. Deve ser respeitado o limite para o valor de $b_{1}$. Assim, tem-se que:

$$
b_{f}=b_{w}+2 \cdot a
$$

O valor de $b_{1}$ é dado pelo maior valor entre:

$$
\begin{gathered}
b_{1} \leq 0,10 \cdot a \\
\mathrm{e} \\
b_{1} \leq 0,50 \cdot b_{2}
\end{gathered}
$$

O valor de $b_{2}$ é a distância entre as faces da nervura. 
Os valores de "a" são estimados e dados em função do comprimento do vão analisado (NBR 6118:2003, seção 14.6.2.2.):

- tramo simplesmente apoiado: $\mathrm{a}=\ell$;

- tramo com momento em uma extremidade: $\mathrm{a}=0,75 \cdot \ell$;

- tramo com momentos nas duas extremidades: $\mathrm{a}=0,60 \cdot \ell$;

- tramo em balanço: $a=2 \cdot \ell$

Com o valor de $b_{f}$ pode-se calcular a profundidade da linha neutra. Conhecida a resistência à compressão do concreto, determina-se a área de armadura necessária para absorver o momento fletor de cálculo atuante na seção transversal estudada.

\subsubsection{Resistência à força cortante}

Caixeta (1998) concluiu que as barras das diagonais da armação treliçadas das vigotas não absorvem as tensões de tração oriundas da força cortante quando o banzo superior da treliça está ancorado abaixo da linha neutra.

Para o EF-96 (1997), a colaboração da diagonal da armação treliçada presente em vigotas pré-moldadas para resistir ao cisalhamento só pode considerada quando a barra superior da armação estiver situada a menos de 4 $\mathrm{cm}$ da superfície superior da laje.

As vigotas treliçadas podem dispensar armadura para resistir à força cortante solicitante $\left(\mathrm{V}_{\mathrm{sd}}\right)$ se esta for menor que à força cortante resistente de cálculo $\left(\mathrm{V}_{\mathrm{Rd} 1}\right)$, que é aquela calculada sem armadura transversal, para elementos sem protensão. Para a NBR 6118:2003, item 19.4.1, a frase anterior pode ser reescrita através da expressão 2.17. 


$$
V_{S d} \leq V_{R d 1}
$$

A resistência de cálculo da força cortante $\left(V_{R d 1}\right)$ é expressa pela equação 2.18.

$$
\begin{aligned}
& V_{R d 1}=\left[\tau_{c} \cdot k \cdot\left(1,2+40 \cdot \rho_{1}\right)\right] \cdot b_{w} \cdot d \\
& f_{c t d}=f_{c t, i n f} / \gamma_{c} \\
& k=1 \text {, para elementos onde } 50 \% \text { da armadura inferior não chega } \\
& k=(1,6-d) \geq 1 \text { ("d" em metros); } \\
& \rho_{1}=\frac{A_{s 1}}{b_{w} \cdot d} \leq 0,02 \text {; }
\end{aligned}
$$

$A_{s 1}$ é a área da armadura de tração que se estende até não menos que $d+l_{b, n e c}$ além da seção considerada;

$b_{w}$ é a largura mínima da seção ao longo da altura útil $d$.

Para elementos sem armadura transversal a verificação da compressão diagonal do concreto é feita pelo cálculo da força cortante resistente de cálculo

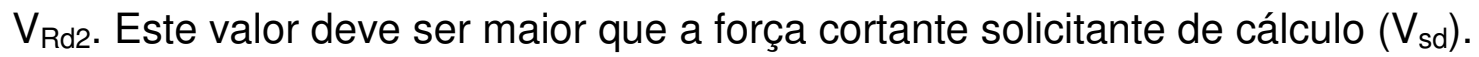

$$
V_{R d 2}=0,5 \cdot \alpha_{v 1} \cdot f_{c d} \cdot b_{w} \cdot 0,9 \cdot d \geq V_{s d}
$$

sendo: $\alpha_{v 1}=\left(0,7-f_{c k} / 200\right) \leq 0,5$, com $f_{c k}$ em MPa;

$$
f_{c d}=f_{c k} / \gamma_{c}
$$

Já o CEB-FIP (1998) recomenda que a força cortante de cálculo seja menor que o valor calculado com a expressão 2.20, equivalente à NBR 6118:2003. 


$$
V_{s d} \leq V_{R d 3}=V_{R d 1}+0,9 \cdot d \cdot \frac{4 \cdot A_{s t}}{l} \cdot f_{y \alpha, d} \cdot \sin \alpha
$$

$$
V_{c u}=\tau_{R d} \cdot b_{1} \cdot d
$$

sendo: $A_{\mathrm{st}}=$ área de cada ramo da seção transversal $\left(\mathrm{em} \mathrm{cm}^{2}\right)$;

$\mathrm{f}_{\mathrm{ya}, \mathrm{d}}=$ tensão de cálculo do aço transversal (não maior que 420 $\mathrm{MPa})$.

\subsubsection{Verificação do cisalhamento na interface}

A evolução da capacidade de resistir à força cortante na interface envolve muitas variáveis. De acordo com o CEB-FIP, algumas delas são: rugosidade da interface, umidade da superfície, limpeza da superfície e forma da seção transversal da treliça.

A verificação do cisalhamento na interface entre vigota e concreto moldado no local é dada pela expressão 2.22 que consta na norma espanhola EF-96 (1997).

$$
V_{d} \leq \beta \cdot \rho \cdot d \cdot f_{c v}
$$

sendo $\beta=$ coeficiente de valor 1,2 para superfícies rugosas e 0,6 para superfícies lisas;

$\rho=$ perímetro crítico, conforme figura 2.17 ;

$d=$ altura útil da seção composta;

$f_{c v}=$ resistência de cálculo ao cisalhamento do concreto moldado no local 


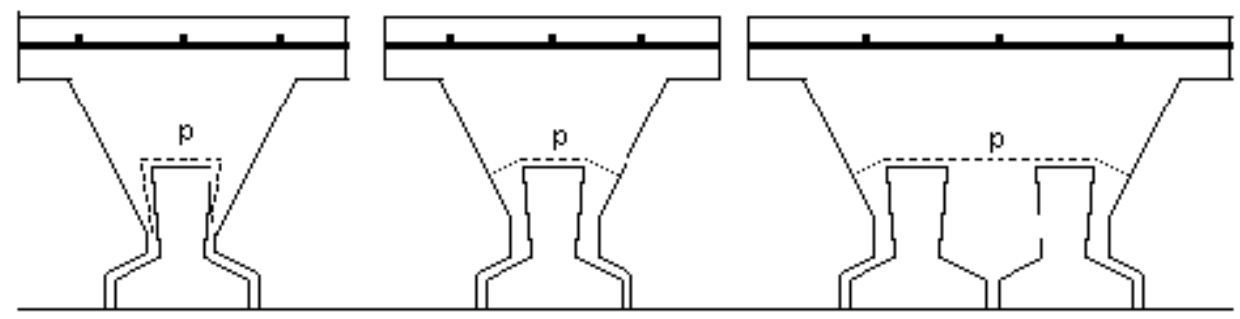

Figura 2.17 - Perímetro de contato entre concretos (EF-96: 1997)

O CEB-FIP (1998) recomenda a mesma expressão, mas acrescenta um fator 0,9 multiplicando toda a inequação e uma parcela de contribuição dos diagonais da treliça.

\subsection{OUTROS ASPECTOS}

\subsubsection{Momento fletor negativo nos apoios}

A seção transversal típica formada entre os eixos das vigotas na laje é em forma de "T". Sendo assim, resiste melhor aos momentos fletores positivos do que aos momentos fletores negativos. A seção de concreto no apoio apresenta uma tendência a plastificar. Isso ocorre porque a área da seção transversal do concreto comprimido é muito diferente, quando se compara o momento fletor negativo com o positivo. $O$ tema se torna ainda mais importante porque a consideração de continuidade favorece a diminuição das flechas e vibração.

É possível e utilizada a redistribuição de momentos. A NBR 6118:2003 permite que isso seja feito, mas impõe limites na posição da linha neutra. $O$ coeficiente de redistribuição, ou, o quanto de momento fletor que poderá ser reduzido, é dado por duas expressões presentes no item 14.6.4.3 da referida norma, para concreto com resistência característica à compressão acima e abaixo de $35 \mathrm{MPa}$. Para estruturas de nós móveis, o valor máximo permitido é de 0,90 e para os outros casos 0,75 . Estes limites podem não ser obedecidos desde que a estrutura seja calculada utilizando a análise não-linear, com verificação explícita da capacidade de rotação de rótulas plásticas. Muitos 
projetistas adotam a linha neutra entre os limites entre os domínios 3 e 4 e calculam o momento fletor máximo resistente para aquela seção de concreto, utilizando ao máximo a resistência do material. Este momento fletor máximo é adotado como o negativo e, assim, obtém-se o valor da área de armadura. É necessário, todavia, corrigir os valores do momento fletor positivo. Segundo Magalhães (2001), este cálculo plástico não garante que os esforços sejam redistribuídos no estado limite último.

Há muitos benefícios nesta redistribuição de momentos, como aqueles citados pela CEB (1998): menor taxa de armadura localizada nas áreas de momentos negativos, portanto, tensões reduzidas na região comprimida da seção; maior liberdade no detalhamento da armadura; diminuição no número de barras de aço na região dos apoios melhorando a concretagem neste local.

Magalhães (2001) realizou ensaios experimentais e teóricos em modelos de lajes formadas por vigotas treliçadas pré-moldadas, estudando o momento fletor negativo nos apoios. Utiliza ensaios de 3 faixas de lajes com $12 \mathrm{~cm}$ de altura e dois vãos de 4,0m, conforme figuras 2.18 e 2.19 .

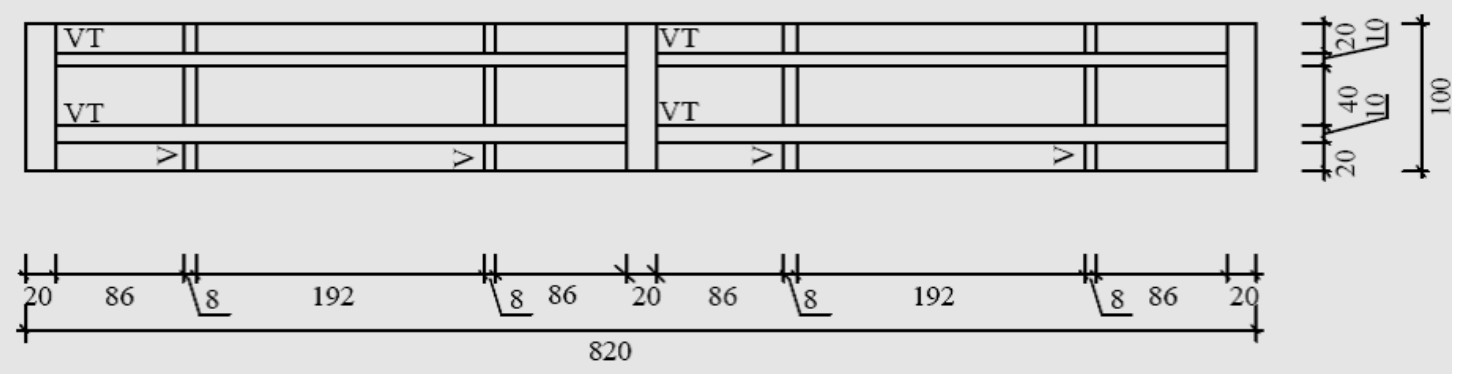

Figura 2.18 - Planta de formas do experimento, em cm (MAGALHAES, 2001)

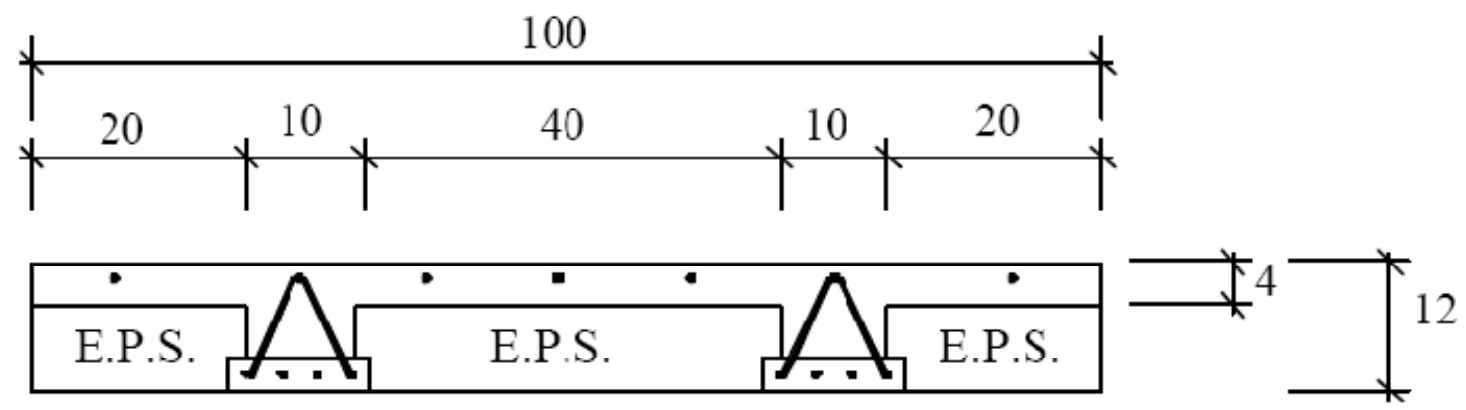

Figura 2.19 - Seção transversal do elemento estrutural, em cm (MAGALHAES, 2001) 
A modelagem numérica considera a não-linearidade física do concreto. Os modelos estudados foram lajes com redistribuição de momento de 15\%, 40\% e outra com apenas uma armadura negativa construtiva. Os resultados obtidos, quando comparados os teóricos e experimentais, foram bem próximos. E diante do número limitado de modelos e pouca variabilidade das propriedades da laje como vão, altura, armadura e carregamento, as conclusões passam a ser limitadas, necessitando de mais estudos sobre o tema.

Uma indicação interessante é a da FIB (2008), Féderátión Internationales du Béton, quando trata de ligações não-confiáveis. Diz que é desejável e nem sempre necessário que a ligação seja completamente rígida. Uma interação parcial é possível. Por isso, as ligações podem ser classificadas em:

- completamente restringidas: a laje é tratada como contínua sobre os apoios tanto nas verificações de ELS quanto ao ELU.

- parcialmente restringidas: a laje é tratada como contínua sobre os apoios para o ELS, mas simplesmente apoiada quanto ao ELU.

Esta indicação da FIB é uma alternativa para a determinação dos momentos fletores negativos sobre os apoios e para todas as verificações de ELS e ELU.

O EUROCODE prEN51037-1 (2004), no item D.3 do anexo D, trata dos momentos negativos nos apoios e aponta que a armação negativa deve absorver um momento fletor arbitrário de 0,15 do momento fletor positivo máximo do vão, adotado como biapoiado $\left(M_{0}\right)$. No entanto, este arranjo não é obrigatório para lajes com vãos menores que 4,5m e carga total aplicada não maior que $2,5 \mathrm{kN} / \mathrm{m}^{2}$.

Carvalho e Figueiredo Filho (2005) mostram através de um exemplo resolvido que a melhor forma de obter um momento negativo resistente necessário para considerar o vão contínuo é o maciçamento da região próxima aos apoios. A determinação da largura desta zona maciça pode ser determinada pela igualdade do momento fletor máximo resistente da nervura com o momento fletor negativo resistente em função de uma distância " $x$ " do apoio. Deste valor, 
subtraído o comprimento do vão, obtêm-se a largura da zona maciça de cada lado do apoio.

\subsubsection{Colapso progressivo}

Um tema muito relacionado às estruturas de concreto pré-moldado é o colapso progressivo. Conhecido também como ruína em cadeia ou colapso desproporcional (principalmente nos Estados unidos), o colapso progressivo vem sendo estudado com mais ênfase desde o famoso acidente do edifício de Ronan Point, em 1968, na Inglaterra (figura 2.20). O NISTIR 7396 (2007) o define como a propagação de uma ruína inicial localizada de modo análogo a uma reação em cadeia que resulta em colapso total ou parcial da estrutura.

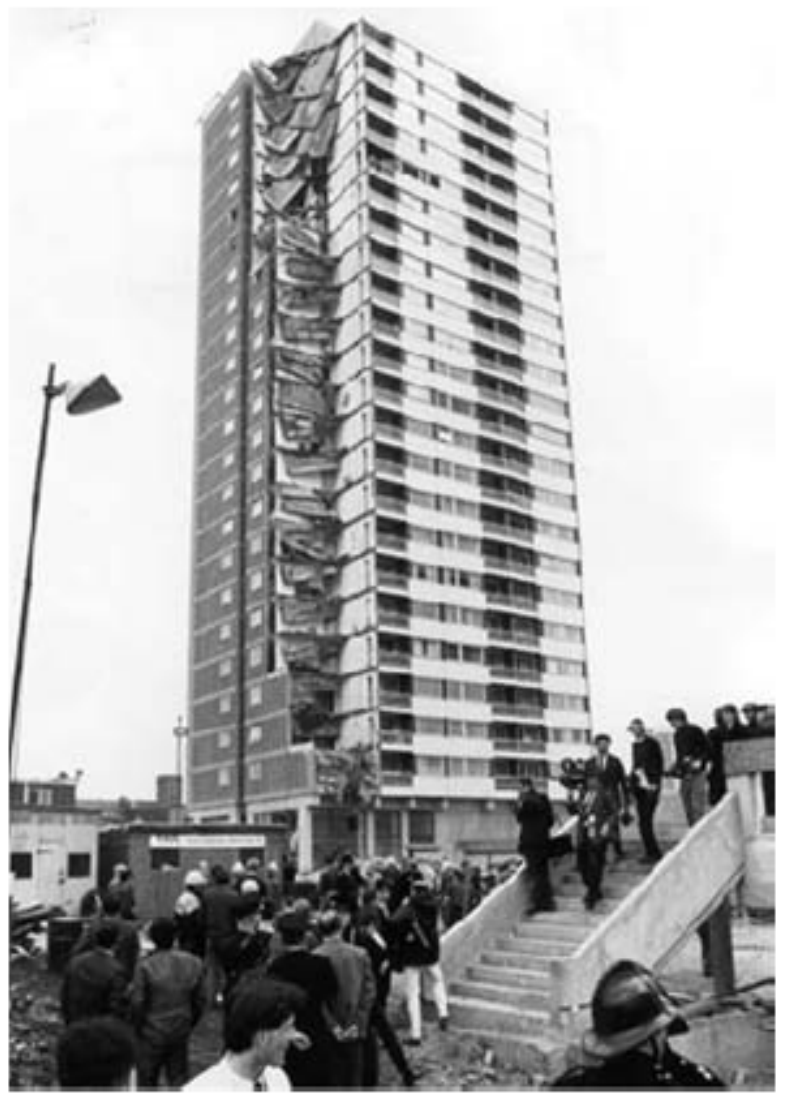

Figura 2.20 - Colapso de Ronan Point, Inglaterra, em 1968 (TAYLOR et.al., 2010) 
Atualmente o tema foi abordado em um texto denominado "Colapso progressivo dos edifícios - Breve introdução" de autoria do profo Antonio Carlos Reis Laranjeiras (2010) publicado no TQS News no33 e utilizou como referência bibliográfica básica o NISTIR 7396 (2007). Laranjeiras (2011) situa o problema exemplificando com casos de colapso progressivo. Quatro características são necessárias para um sistema estrutural apresentar robustez e integridade: continuidade, redundância, ductilidade e resistência. As estruturas pré-moldadas apresentam sua maior deficiência na continuidade, nas ligações entre seus elementos.

Elliot (1996) explica que com a crescente deformação do elemento estrutural tem-se uma considerável parcela de momento de distribuição longe da região crítica. Isto será seguido de grandes rotações plásticas que serão guiadas para a ação de membrana no pavimento. A figura 2.21 mostra as etapas da formação da ação de membrana em lajes maciças.

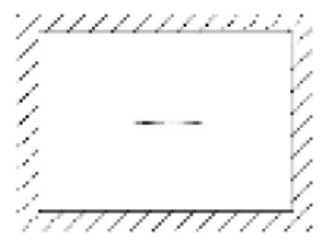

(a) Início das linhas de ruptura membrana

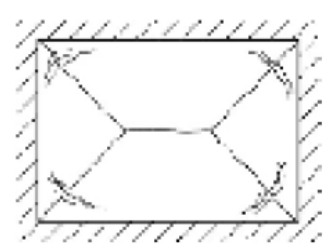

(d) Surgimento da ação de membrana

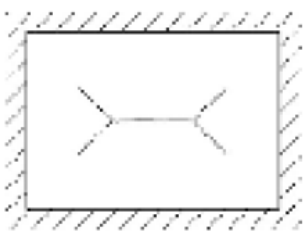

(b) Formação das linhas de ruptura

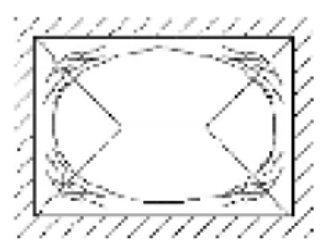

(e) Desenvolvimento da ação de membrana

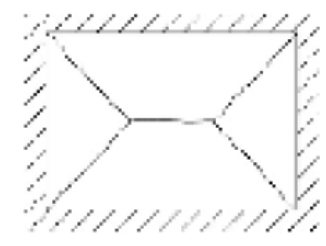

(c) Linhas de ruptura completas

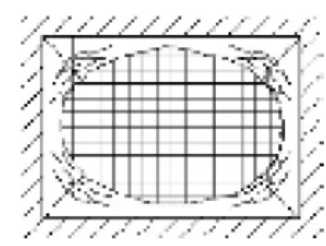

(e) Ação de membrana no estado limite

Figura 2.21 - Formação da ação de membrana na laje maciça (adaptado de ZHANG et al., 20ก9)

El Debs (2000) mostra que para evitar que a fissuração na estrutura se propague rapidamente é necessário fornecer meios alternativos para a transferência de carga. Três mecanismos são citados: ação de balanço dos painéis portantes, ação de viga e de arco dos painéis portantes e ação de membrana ou cabo em vãos sucessivos de lajes ou vigas. 
Laranjeiras (2011) mostra dois métodos para combater o colapso progressivo: o método indireto e o método direto. O primeiro está baseado em detalhes e medidas que devem ser prescritas para que haja o mínimo de conectividade entre os elementos estruturais, sem que seja necessária uma análise adicional da estrutura. Sua aplicação é genérica. Já o método direto baseia-se em uma análise numérica para compreender a resposta da estrutura diante de uma ação excepcional específica. Podem ser citados como métodos diretos o Método de Caminhos Alternativos (ou "Alternate Load Path Method", em inglês) e o Método da Resistência Localizada Específica.

Para que os caminhos alternativos se formem para a transferência de cargas é necessário utilizar armaduras adicionais, não previstas no cálculo tradicional da estrutura. Tais armaduras são amarrações ou tirantes ("ties", em inglês) dispostos de diferentes formas. As figuras 2.22 extraída de Bailey (2004) assim como a figura 2.23 extraída de NISTIR 7396 (2007) mostram um arranjo de amarrações ou tirantes.

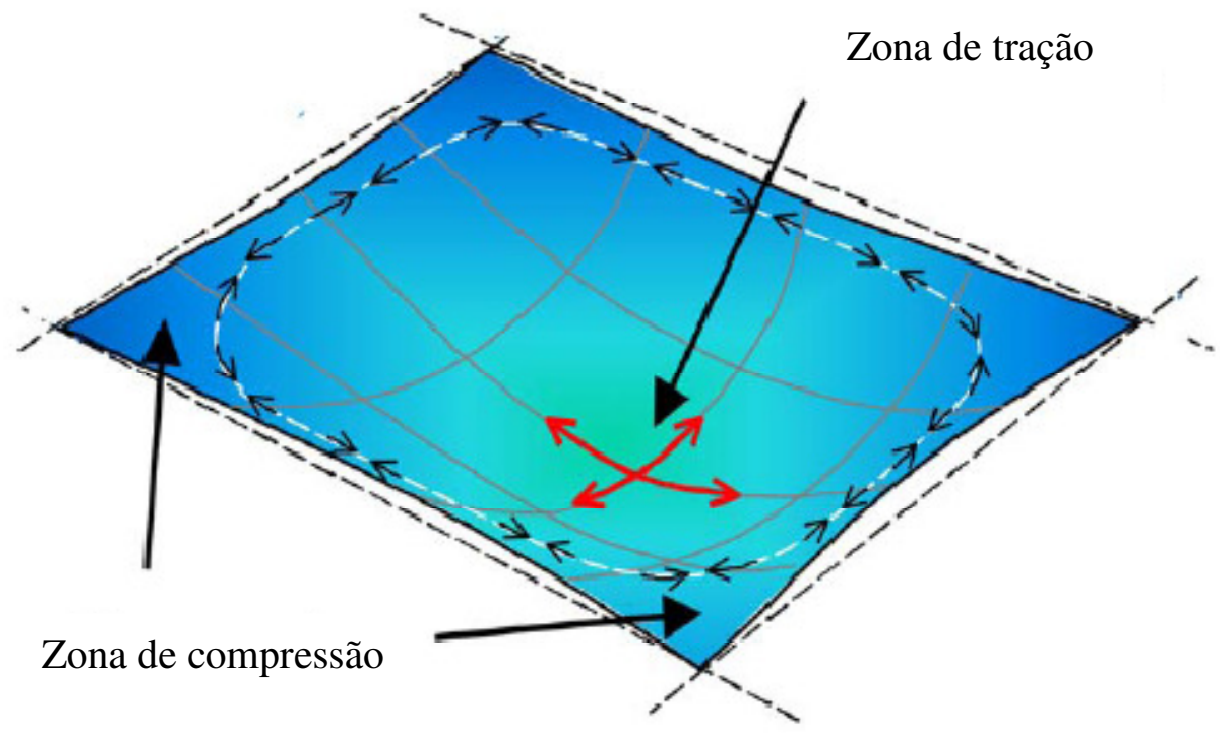

Figura 2.22 - Ação de membrana em lajes sem restrição horizontal em seu perímetro (adaptado de BAILEY, 2004) 


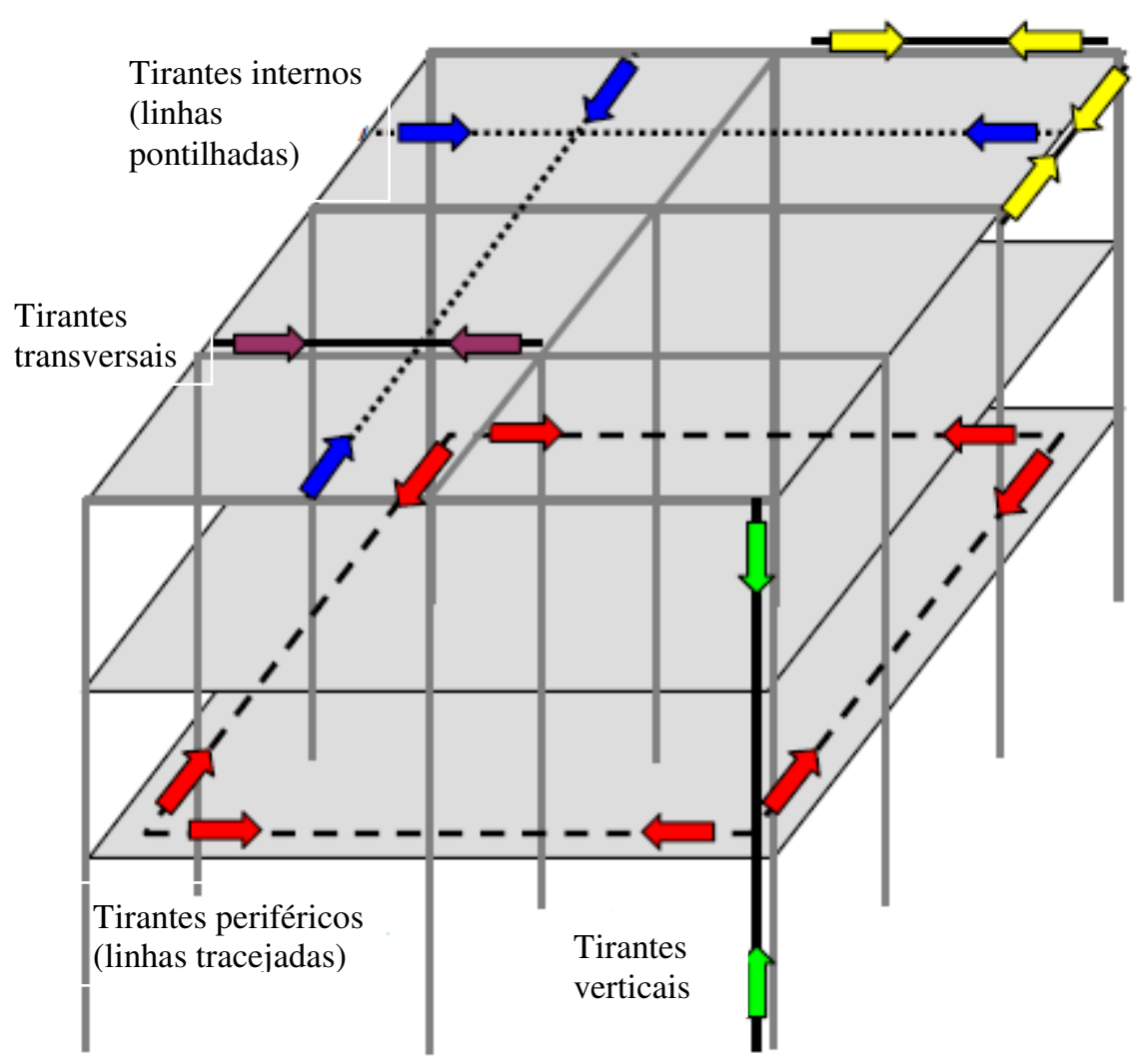

Figura 2.23 - Diferentes tipos de tirantes incorporados para prover a integridade estrutural (NISTIR 7396)

Uma questão a ser discutida é como calcular a armadura adicional para absorver as tensões de tração provocadas por um eventual caso de colapso progressivo, como por exemplo, a perda de uma viga interna ou externa devida a uma explosão. A referência básica utilizada para calcular a área de armadura necessária é Elliot (1996). Este mostra as equações 2.23 a 2.25 da norma britânica BS 8110 de 1985. A força horizontal do tirante $F_{t}(\mathrm{em} \mathrm{kN} / \mathrm{m})$ é dada pela equação 2.23 onde " $n$ " é o número pavimentos, incluindo o térreo. O menor dos dois valores deve ser o escolhido. Além disso, o valor de $F_{t}$ já é considerado como de cálculo e não característico. Assim, não está sujeito à majoração pelos coeficientes de segurança.

$$
F_{t}=(20+4 \cdot n) \text { ou } 60 \mathrm{kN} / \mathrm{m}
$$


Caso o carregamento total uniforme aplicado na laje referente à carga permanente e sobrecarga de utilização for maior que $7,5 \mathrm{kN} / \mathrm{m}^{2}$ e/ou o vão teórico entre pilares na direção do tirante for maior que 5 metros deve-se multiplicar a força do tirante por um fator majorador denominado $F_{t}$.

$$
F_{t}^{\prime}=\left[\frac{\left(g_{k}+q_{k}\right)}{7,5}\right] \cdot\left[\frac{l_{r}}{5}\right]
$$

ou

$$
F_{t}^{\prime}=1,0 \cdot F_{t}
$$

Com posse do valor da força no tirante, calcula-se a área necessária de armadura, através da tensão de cálculo na armadura. Deve-se atentar ao detalhe do comprimento de ancoragem necessário para as barras de aço que compõem a armadura.

Algumas das regras gerais para prevenir o colapso progressivo segundo 0 NISTIR 7396 (2007) e que também são citadas por Laranjeiras (2011) são:

- manter contínua (prolongar) parte das armações inferiores e superiores nas duas direções;

- estender as extremidades das armaduras para dentro de vigas e pilares a fim de aumentar a capacidade resistente a uma inversão de cargas;

- realizar emendas distante das extremidades e do meio do vão.

Laranjeiras (2011) afirma, com base no texto da NISTIR 7396 (2007) que "...As lajes de piso podem suportar cargas sob forma de membrana com grandes deformações, quando solicitada além de sua resistência à flexão; nesses casos, no entanto, a armação da laje deve ser capaz de desenvolver sua capacidade de escoamento".

Outra recomendação para evitar a propagação do colapso progressivo em edifícios de concreto armado em geral é a compartimentação vertical ou horizontal. A vertical consiste em projetar pavimentos robustos, que possam absorver cargas elevadas, e impedir que o colapso continue se propagando. A 
compartimentação horizontal consiste em prever juntas de separação, dividindo o edifício em "setores" independentes.

Para mais detalhes e informações sobre este assunto consultar bibliografia mais completa como a NISTIR 7396 (2007), o EUROCODE 2 ou a norma britânica BS 8110 .

\subsubsection{Verificação em situação de incêndio}

As razões que nos levam a verificar lajes em situação de incêndio são as perdas de resistência e rigidez da estrutura. A seção transversal, que já é pequena, tende a ser reduzida com o desplacamento do concreto, conhecido em inglês como "spalling", ficando a armadura exposta à ação térmica. Este lascamento ocorre quando a "(...) pressão do vapor dentro do material aumenta a uma taxa maior que o alívio da pressão pela dispersão de vapor na atmosfera" (MEHTA e MONTEIRO, 2008, p.151). Com os cobrimentos menores em relação aos outros elementos estruturais, esta ação é potencializada. Com isso, a deformação do aço se torna excessiva e, assim, tem-se a perda da resistência e da aderência com o concreto (GOMIDE et al., 2009). O módulo de elasticidade também é bastante reduzido. Uma explicação para esta queda pode ser atribuída à microfissuração na zona de transição na interface entre a pasta de cimento hidratada e o agregado, segundo Mehta e Monteiro (2008).

Os elementos estruturais devem atender a requisitos de estanqueidade $\mathrm{e}$ isolamento por um determinado período de tempo que possibilite (NBR 14432:2001):

- fuga dos ocupantes da edificação em condições de segurança;

- segurança das operações de combate ao incêndio;

- minimização de danos a edificações adjacentes e à infra-estrutura pública.

Como dimensionar o elemento estrutural em função do incêndio? Existem modelos matemáticos que simulam um incêndio real e é caracterizado em função de parâmetros como o grau de ventilação, por exemplo. A curva mais 
difundida pela comunidade internacional e utilizada pela NBR 14432:2001 é a curva da ISO 834 e é denominada de curva de incêndio-padrão. A expressão de origem desta curva é descrita a seguir pela equação 2.26 .

$$
\theta_{g}=\theta_{o}+345 \cdot \log (8 \cdot t+1)
$$

sendo $t$ = tempo, em minutos;

$\theta_{o}=$ temperatura do ambiente antes do início do aquecimento, em graus Celsius, geralmente tomada igual a $20^{\circ} \mathrm{C}$.

$\theta_{g}=$ temperatura dos gases, em graus Celsius, no instante $t$.

Segundo a NBR 14432:2001, o tempo requerido de resistência ao fogo (TRRF) é o “(...) tempo mínimo de resistência ao fogo de um elemento construtivo quando sujeito ao incêndio-padrão". Para cada tipo de edificação, em função da sua ocupação, tem-se um valor estabelecido por normas ou códigos do TRRF. A NBR 14432:2001 apresenta a tabela A.1 em seu Anexo A com os valores de TRRF para cada ocupação/uso da edificação e sua altura descrita na tabela 2.9 deste trabalho. Cada grupo apresenta uma divisão e é descrita no Anexo B da NBR 14432:2001.

A laje em situação de incêndio se torna muito importante, pois impede a propagação do incêndio pela edificação, de um pavimento a outro. Apresenta a função de compartimentação do incêndio, minimizando a sua propagação pelos outros pavimentos. 
Tabela 2.9 - Tempos requeridos de resistência ao fogo (TRRF), em minutos. (extraído da tabela A.1, NBR 14432:2001)

\begin{tabular}{|c|c|c|c|c|c|c|c|c|c|}
\hline \multirow[b]{2}{*}{ Grupo } & \multirow[b]{2}{*}{ Ocupaçåo/uso } & \multirow[b]{2}{*}{ Divisão } & \multicolumn{2}{|c|}{$\begin{array}{l}\text { Profundidade do } \\
\text { subsolo }\end{array}$} & \multicolumn{5}{|c|}{ Altura da edificaçāo } \\
\hline & & & $\begin{array}{l}\text { Classe } \mathrm{S}_{2} \\
\mathrm{~h}_{\mathrm{s}}>10 \mathrm{~m}\end{array}$ & $\begin{array}{l}\text { Classe } S_{1} \\
h_{5} \leq 10 m\end{array}$ & $\begin{array}{c}\text { Classe } P_{1} \\
h \leq 6 m\end{array}$ & $\begin{array}{c}\text { Classe } P_{2} \\
6 m<h \leq 12 m\end{array}$ & $\begin{array}{c}\text { Classe } P_{3} \\
12 m<h \leq 23 m\end{array}$ & $\begin{array}{c}\text { Classe } P_{4} \\
23 m<h \leq 30 m\end{array}$ & $\begin{array}{l}\text { Classe } P_{5} \\
h>30 \mathrm{~m}\end{array}$ \\
\hline A & Residencial & $\mathrm{A}-1$ a $\mathrm{A}-3$ & 90 & $60(30)$ & 30 & 30 & 60 & 90 & 120 \\
\hline $\mathrm{B}$ & Serviços de hospedagem & B-1 e B-2 & 90 & 60 & 30 & $60(30)$ & 60 & 90 & 120 \\
\hline $\mathrm{C}$ & Comercial varejista & $\mathrm{C}-1$ a C-3 & 90 & 60 & $60(30)$ & $60(30)$ & 60 & 90 & 120 \\
\hline D & $\begin{array}{c}\text { Serviços profissionais, } \\
\text { pessoais e técnicos }\end{array}$ & D-1 a D-3 & 90 & $60(30)$ & 30 & $60(30)$ & 60 & 90 & 120 \\
\hline$E$ & $\begin{array}{l}\text { Educacional e cultura } \\
\text { física }\end{array}$ & $E-1$ a $E-6$ & 90 & $60(30)$ & 30 & 30 & 60 & 90 & 120 \\
\hline$F$ & $\begin{array}{l}\text { Locais de reunião de } \\
\text { público } \\
\end{array}$ & $\begin{array}{c}F-1, F-2, F-5, \\
F-6 \text { e F-8 }\end{array}$ & 90 & 60 & $60(30)$ & 60 & 60 & 90 & 120 \\
\hline \multirow{2}{*}{ G } & \multirow{2}{*}{ Serviços automotivos } & $\begin{array}{c}\text { G-1 e G-2 nāo } \\
\text { abertos } \\
\text { lateralmente e } \\
\text { G-3 a G-5 }\end{array}$ & 90 & $60(30)$ & 30 & $60(30)$ & 60 & 90 & 120 \\
\hline & & $\begin{array}{c}\text { G-1 e G-2 } \\
\text { abertos } \\
\text { lateralmente }\end{array}$ & 90 & $60(30)$ & 30 & 30 & 30 & 30 & 60 \\
\hline $\mathrm{H}$ & $\begin{array}{c}\text { Serviços de saúde e } \\
\text { institucionais }\end{array}$ & $\mathrm{H}-1$ a $\mathrm{H}-5$ & 90 & 60 & 30 & 60 & 60 & 90 & 120 \\
\hline \multirow{2}{*}{ i } & \multirow{2}{*}{ Industrial } & $1-1$ & 90 & $60(30)$ & 30 & 30 & 60 & 90 & 120 \\
\hline & & $1-2$ & 120 & 90 & $60(30)$ & $60(30)$ & $90(60)$ & $120(90)$ & 120 \\
\hline \multirow{2}{*}{$J$} & \multirow{2}{*}{ Depósitos } & $\mathrm{J}-1$ & 90 & $60(30)$ & 30 & 30 & 30 & 30 & $\because 60$ \\
\hline & & $\mathrm{J}-2$ & 120 & 90 & 60 & 60 & $90(60)$ & $120(90)$ & 120 \\
\hline
\end{tabular}


A verificação da estrutura deve ser realizada utilizando a combinação para ações excepcionais, já que o tempo de recorrência do evento é grande. São adotados para a carga variável fatores de redução $\Psi_{2 j}$ correspondentes à combinação quase permanente. A força normal de cálculo em situação de incêndio, $\mathrm{S}_{\mathrm{d}, \mathrm{fi}}$ deve ser menor ou igual à resistência de cálculo.

Para as estruturas de concreto em situação de incêndio, a NBR 15200:2004 descreve quatro métodos para verificar a estrutura: método tabular, método simplificado de cálculo, método geral de cálculo e método experimental. Este trabalho discorre sobre o método tabular, bastante prático e direto.

O método tabular é baseado no EUROCODE de 2002 e apresenta algumas adaptações para os valores usuais dos elementos estruturais no Brasil. Nenhuma verificação é necessária. Basta que cada tipo de elemento estrutural, em função do TRRF, atenda às dimensões mínimas prescritas pela NBR 15200:2004. Entre elas estão: espessura das lajes, largura das vigas e, principalmente, distância entre o eixo da armadura longitudinal e a face do concreto exposta ao fogo $\left(c_{1}\right)$. É considerada apenas a armadura de flexão, pois, usualmente, as peças rompem nos ensaios em situação de incêndio quando submetidas à flexão ou flexo-compressão e não por cisalhamento.

O cálculo da distância $c_{1}$ para elementos com armaduras dispostas em várias camadas será a média das distâncias do eixo das barras até a face exposta ao fogo $\left(c_{1 m}\right)$. Não será descrito aqui as fórmulas para calcular o $c_{1 m}$ já que são utilizadas mais para vigas e pilares, e não lajes, objeto de estudo deste trabalho. O TRRF pode ser reduzido através da utilização do método do tempo equivalente.

Uma das adaptações do EUROCODE de 2002 para a NBR 15200:2004 é a inclusão da espessura dos revestimentos no cálculo das espessuras mínimas e distâncias $c_{1}$. Porém, deve ser incombustível e aderente às faces do concreto durante o incêndio. Para mais detalhes, consultar a NBR 13528:1995 que trata de revestimentos de paredes e tetos de argamassas inorgânicas.

As tabelas 2.10 a 2.13 ilustram as dimensões mínimas para as lajes, com ênfase paras as tabelas 2.12 e 2.13 que estão relacionadas às lajes formadas por vigotas com armação treliçada. A norma ainda fornece mais tabelas para outros elementos como viga, pilar e tirante. 
Tabela 2.10 - Dimensões mínimas para lajes apoiadas em vigas (NBR 15200:2004)

\begin{tabular}{|c|c|c|c|c|}
\hline \multirow{3}{*}{$\begin{array}{c}\text { TRRF } \\
\text { min }\end{array}$} & \multirow{3}{*}{$\begin{array}{c}h^{\star} \\
\mathrm{mm}\end{array}$} & \multicolumn{3}{|c|}{$\begin{array}{c}c_{1} \\
\mathrm{~mm}\end{array}$} \\
\hline & & \multicolumn{2}{|c|}{ Armada em duas direções } & \multirow{2}{*}{$\begin{array}{l}\text { Armada nume } \\
\text { direção }\end{array}$} \\
\hline & & $\ell_{y} / \ell_{x} \leq 1,5$ & $1,5<\ell_{y} / \ell_{x} \leq 2$ & \\
\hline 30 & 60 & 10 & 10 & 10 \\
\hline 60 & 80 & 10 & 15 & 20 \\
\hline 90 & 100 & 15 & 20 & 30 \\
\hline 120 & 120 & 20 & 25 & 40 \\
\hline
\end{tabular}

Tabela 2.11 - Dimensões mínimas para lajes lisas ou cogumelos (NBR 15200:2004)

\begin{tabular}{|c|c|c|}
\hline $\begin{array}{c}\text { TRRF } \\
\min \end{array}$ & $\begin{array}{c}h \\
\mathrm{~mm}\end{array}$ & $\begin{array}{c}c_{1} \\
\mathrm{~mm}\end{array}$ \\
\hline 30 & 150 & 10 \\
\hline 60 & 180 & 15 \\
\hline 90 & 200 & 25 \\
\hline 120 & 200 & 35 \\
\hline * Dimensỏes mínimas para garantir a funçäo corta-fogo. \\
\hline
\end{tabular}

Tabela 2.12 - Dimensões mínimas para lajes nervuradas biapoiadas (NBR 15200:2004)

\begin{tabular}{|c|c|c|c|c|}
\hline \multirow{2}{*}{$\begin{array}{c}\text { TRRF } \\
\text { min }\end{array}$} & \multicolumn{3}{|c|}{$\begin{array}{c}\text { Nervuras } \\
\text { Combinaçőes de } b_{\min } / c_{1}^{1)} \\
\mathrm{mm} / \mathrm{mm}\end{array}$} & \multirow{2}{*}{$\begin{array}{l}\text { Capa } \\
\mathrm{h} / \mathrm{c}_{1}{ }^{2} \\
\mathrm{~mm} / \mathrm{mm}\end{array}$} \\
\hline & 1 & 2 & 3 & \\
\hline 30 & $80 / 15$ & & & $80 / 10$ \\
\hline 60 & $100 / 35$ & $120 / 25$ & $190 / 15$ & $80 / 10$ \\
\hline 90 & $120 / 45$ & $160 / 40$ & $250 / 30$ & $100 / 15$ \\
\hline 120 & $160 / 60$ & $190 / 55$ & $300 / 40$ & $120 / 20$ \\
\hline $\begin{array}{l}\text { 1) } b_{\text {min }} \text { corresp } \\
\text { 2) } h \text { correspon } \\
{ }^{*} \text { Dimensöes }\end{array}$ & $\begin{array}{l}\text { a mínima c } \\
\text { a laje. } \\
\text { garantir a }\end{array}$ & & & \\
\hline
\end{tabular}


Tabela 2.13 - Dimensões mínimas para lajes nervuradas apoiadas em três ou quatro lados (NBR 15200:2004)

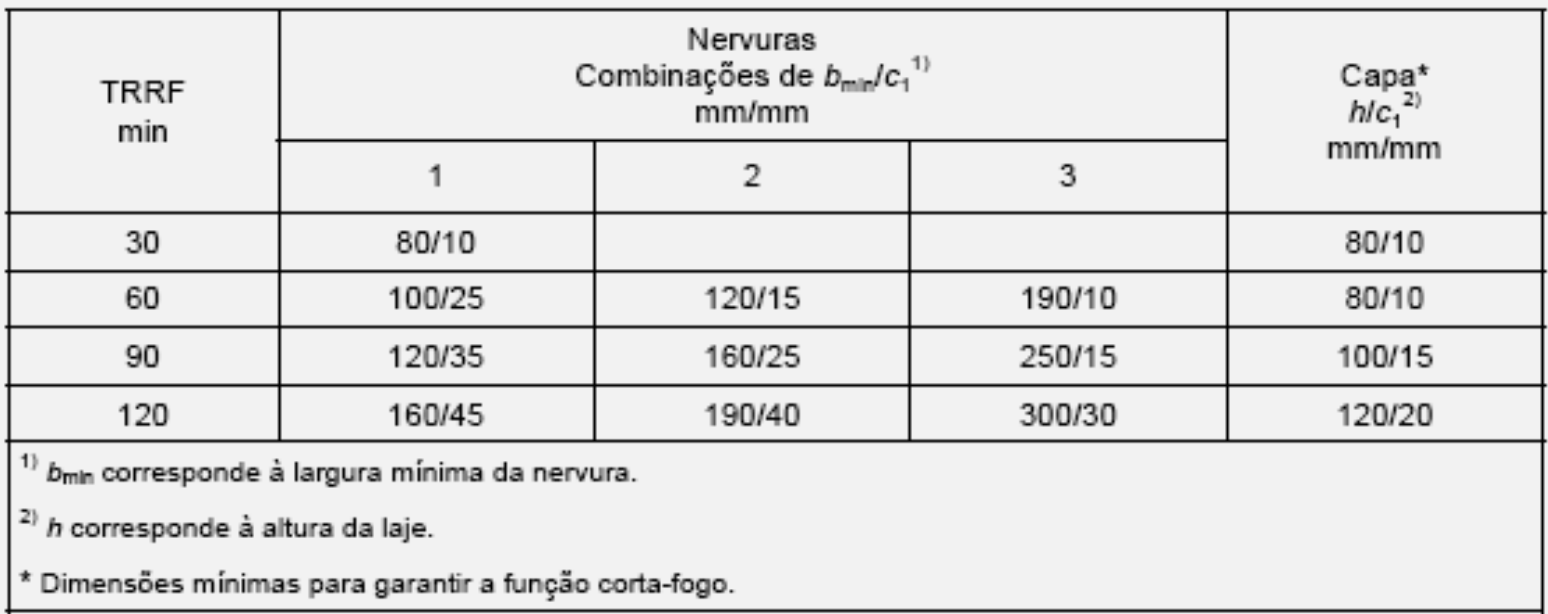

Conforme diz Costa (2008), o método tabular foi elaborado pela NBR 14432:2001 para abranger situações críticas, com elementos em incêndiopadrão sem qualquer tipo de proteção ativa (sprinklers, brigada de incêndio) ou passiva (características térmicas da compartimentação).

No trabalho de Gomide et al. (2009) foi feita uma análise do comportamento de lajes de $16 \mathrm{~cm}$ de altura formadas por vigotas treliçadas prémoldadas em situação de incêndio. O Tempo Requerido de Resistência ao Fogo (TRRF) é definido em função das características da edificação. Dessa forma, comparou-se o momento de cálculo atuante na laje com o momento resistente em situação de incêndio, segundo o EUROCODE 2 (prEN-1-2:2004), e com TRRF de 30, 60, 90 e 120 minutos, segundo a tabela 2.14 .

Tabela 2.14 - Dimensionamento da laje (Tabela 1: GOMIDE et al., 2009)

\begin{tabular}{|c|c|c|c|c|c|}
\hline \multirow{3}{*}{$\begin{array}{l}\text { Carregamentos } \\
\text { Peso Próprio (g): }\end{array}$} & \multirow{3}{*}{$\begin{array}{c}\text { Valores } \\
\left(\mathrm{kN} / \mathrm{m}^{2}\right)\end{array}$} & \multirow{2}{*}{\multicolumn{2}{|c|}{$\begin{array}{c}\text { Características } \\
\text { Geométricas }\end{array}$}} & \multirow{2}{*}{\multicolumn{2}{|c|}{$\begin{array}{l}\text { Dimensionamento } \\
\text { Momentos (kN.m) }\end{array}$}} \\
\hline & & & & & \\
\hline & & vão & $4,00 \mathrm{~m}$ & $M_{d, \text { máx }}$ (faixa de $1 \mathrm{~m}$ ) & 14,840 \\
\hline Revestimento $(\mathrm{g})$ : & 1,0 & intereixo & $0,42 \mathrm{~m}$ & $\mathrm{M}_{\mathrm{d}, \text { máx }}($ nervura $)$ & 6,233 \\
\hline Sobrecarga $(q)$ : & 2,0 & $\mathrm{~h}_{\text {Total }}$ & $0,16 \mathrm{~m}$ & $\mathrm{~A}_{\mathrm{s}}\left(\mathrm{cm}^{2}\right)$ & 1,13 \\
\hline Total $(g+q)$ & 5,3 & $h_{\text {Capa }}$ & $0,04 \mathrm{~m}$ & $\mathrm{~A}_{\mathrm{s}}$ adotada & $4 \curvearrowleft 6,0 \mathrm{~mm}$ \\
\hline
\end{tabular}

Notas: Carregamento de peso próprio obtido considerando-se recomendações de fabricantes nacionais e utilização de lajotas cerâmicas;

Carregamento de revestimento obtido considerando-se revestimento de piso cerâmico;

Sobrecarga obtida considerando-se edificação para escritório. 
Os resultados obtidos, conforme tabela 2.15, mostraram que a laje foi verificada com 30 e 60 minutos de TRRF, mas com 90 e 120 minutos, o momento resistente é menor que o atuante. O cobrimento pequeno faz com que a armadura positiva da laje tenha um aumento na temperatura e diminuição na resistência de cálculo do aço $\left(f_{y d, \theta}\right)$. Este, por sua vez, tem uma queda brusca quando o TRRF passa de 60 para 90 minutos.

Tabela 2.15 - Comparação entre momentos atuantes e resistentes (tabela 3: GOMIDE et al., 2009)

\begin{tabular}{|c|c|c|c|c|c|c|c|c|c|}
\hline \multirow{3}{*}{\multicolumn{2}{|c|}{$\begin{array}{l}\text { Mom. } \\
\text { Atuante } \\
\text { (kN.m) }\end{array}$}} & \multicolumn{8}{|c|}{ Momentos Resistentes (kN.m) } \\
\hline & & \multicolumn{2}{|c|}{ TRRF 30} & \multicolumn{2}{|c|}{ TRRF 60} & \multicolumn{2}{|c|}{ TRRF 90} & \multicolumn{2}{|c|}{ TRRF 120} \\
\hline & & $\mathrm{X}_{\mathrm{f}}(\mathrm{cm})$ & $\mathrm{M}_{\mathrm{fi}}$ & $\mathrm{X}_{\mathrm{fi}}(\mathrm{cm})$ & $\mathrm{M}_{\mathrm{fi}}$ & $\mathrm{X}_{\mathrm{fi}}(\mathrm{cm})$ & $M_{\mathrm{fi}}$ & $X_{f(}(\mathrm{cm})$ & $\mathrm{M}_{\mathrm{fi}}$ \\
\hline $\mathrm{M}_{\mathrm{dx}}$ & 3,80 & 1,09 & 9,15 & 0,62 & 5,22 & 0,13 & 1,16 & 0,13 & 1,08 \\
\hline
\end{tabular}

Segundo Gomide et al. (2009) uma solução a ser adotada para resolver o problema seria aplicar revestimentos protetores sob a laje. Isto impediria a elevação brusca da temperatura na armadura. Outra alternativa é aumentar os cobrimentos das barras de aço.

Outra referência importante é o EUROCODE EN 15037-2:2004 que trata exclusivamente dos critérios para controle da qualidade dos blocos de enchimento de lajes que utilizam vigotas. Em seu anexo B (informativo), de resistência ao fogo, os blocos devem resistir ao incêndio segundo períodos de tempo regulados pela norma, de acordo com o tipo de vigota e elemento de enchimento.

\subsubsection{Comportamento estrutural na fase de montagem}

Um importante aspecto a ser considerado no dimensionamento de uma laje pré-moldada que utiliza vigotas treliçadas é a verificação estrutural nas fases de montagem e posterior concretagem da capa. A distância entre as linhas de 
escora das lajes pode ser racionalizada. DROPPA JR. e EL DEBS (2000) realizaram um estudo teórico-experimental sobre este assunto. O modelo a ser utilizado para a análise teórica é o da viga equivalente, como sugerem Droppa Jr. e El Debs (2000). As ações atuantes nesta fase da construção são devido ao peso próprio das vigotas, material de enchimento e concreto moldado no local, além da sobrecarga de utilização (transporte de material, utilização de equipamentos etc.). Dessa forma, a ruína das vigotas, quando submetidas à flexão, pode ser por: (DROPPA JR. e EL DEBS, 2000, p.4):

- Flambagem do banzo superior, devido a momentos positivos;

- Resistência da armadura tracioanada do banzo inferior ou superior, conforme sentido do momento fletor;

- Flambagem da diagonal comprimida, devido à força cortante;

- Resistência da solda solicitada por cisalhamento entre o banzo e a diagonal, devido à força cortante.

Esta última causa de ruína foi estudada por Terni et al. (2004). Foram comparados os valores normativos com os valores nominais da resistência da solda entre o banzo superior e os diagonais nas armações treliçadas. Nos ensaios realizados, os valores de esforço na solda foram facilmente ultrapassados pelo mínimo exigido pela norma NBR 14862, correspondente aos "Requisitos para armações treliçadas". Supondo 95\% de probabilidade da resistência dos corpos-de-prova serem maiores que a resistência característica estabelecida por norma, associando com o mesmo conceito utilizado para o cálculo do $f_{c k}$, Terni et al. (2004) obteve valores $448 \%$ superiores ao estabelecido pela norma NBR 14862.

O EUROCODE EN 15037-1 fornece no seu anexo normativo $\mathrm{H}$, todas as verificações e testes (flexão e cisalhamento) a serem feitos para verificar a segurança das vigotas na fase de montagem das lajes formadas por vigotas treliçadas. A figura 2.24 extraída do EUROCODE EN 15037-1: 2004, anexo H, mostra as combinações de carregamentos das cargas permanentes com as acidentais, que podem mudar ao longo do vão da laje. Cada um dos carregamentos é multiplicado por fatores de segurança. Estas cargas acidentais 
são o peso do concreto fresco e cargas temporárias durante a fase de construção (1,5 kN aplicado no meio do vão para montagem sem escoras e 1,0 kN para montagem com escoramento situada no meio do vão das escoras).

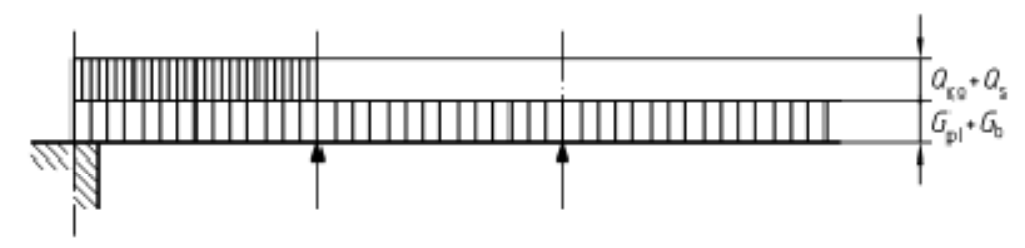

combinação 1

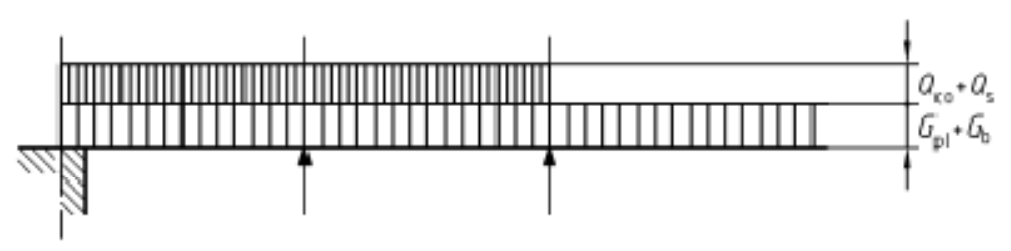

combinação 2

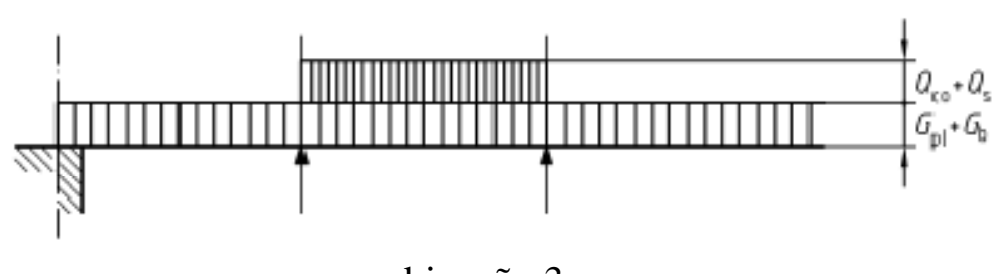

combinação 3

Figura 2.24 - Combinação de carregamentos (EN 15037-1:2004)

\subsubsection{Disposições construtivas}

Quando há concorrência de nervuras, admite-se um desvio " $c$ " inferior a distância reta entre as faces " $s$ " em apoios internos, e até $5 \mathrm{~cm}$ em apoios com balanço, segundo a EF-96 (1997). Ver figura 2.25 que mostra o desvio. Para o CEB-FIP (1998), o desvio máximo para lajes adjacentes em balanço é de $4 \mathrm{~cm}$. 

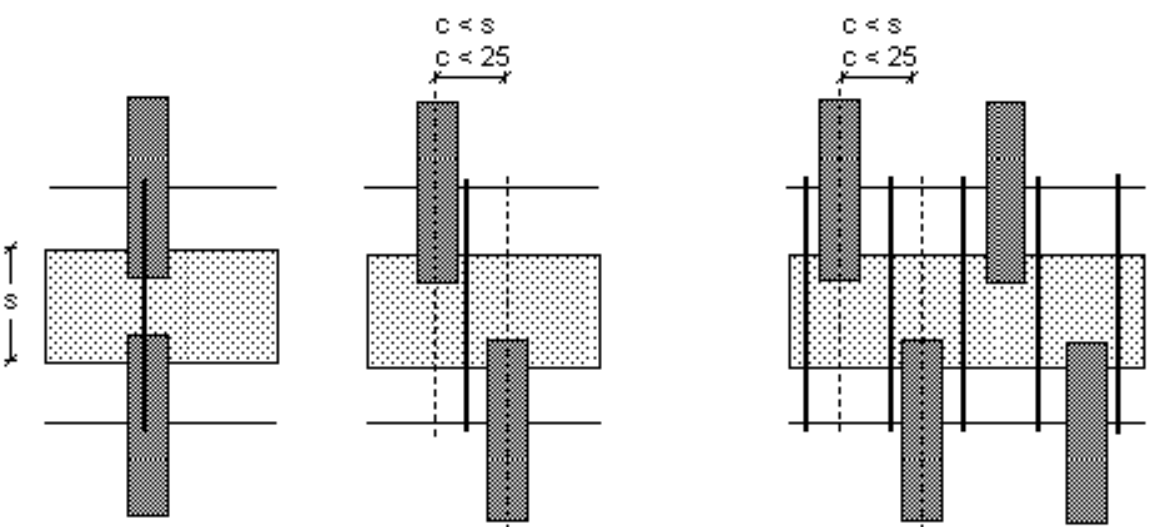

Figura 2.25 - Concorrência de nervuras (EF-96: 1997)

Quando uma vigota se encontra com outra perpendicularmente, a sua armadura negativa será ancorada por prolongação reta. No caso de balanços com nervuras perpendiculares a tramos adjacentes, o comprimento de ancoragem reta será maior que o comprimento do balanço e duas vezes o valor do intereixo (figura 2.26). Segundo a EF-96 (1997) se garante a resistência à compressão da parte inferior da laje através do maciçamento da região. Isto ajuda a reduzir a torção da viga de apoio.

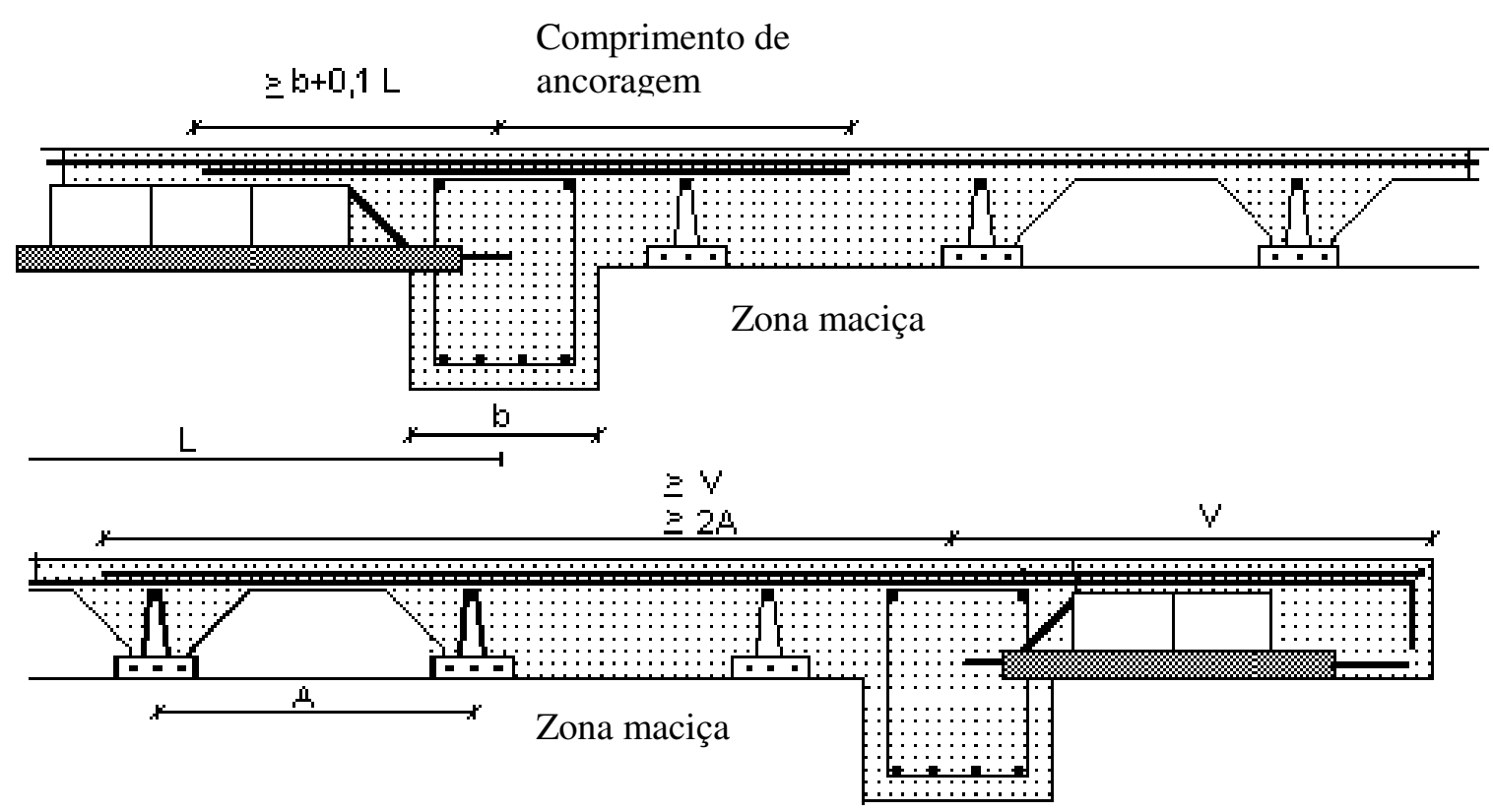

Figura 2.26 - Encontro de vigotas perpendiculares (EF-96: 1997) 
O detalhe do apoio da vigota nas vigas internas ou externas também merece destaque. A norma espanhola EF-96:1997 classifica os apoios em diretos e indiretos. Os diretos são aqueles em que a vigota apoio em uma parede ou uma viga de altura maior que a laje. Já o indireto é o caso em que a vigota apóia em uma viga plana, de mesma altura que a laje. Em ambos os casos, devem-se deixar uma faixa maciça de laje de no mínimo $10 \mathrm{~cm}$ ao lado da viga de apoio (figura 2.27). A vigota deve de prolongar até a viga, de uma distância $I_{1}$. A ancoragem da armadura pode ser por penetração da vigota, prolongação da armadura da vigota ou por transpasse (figuras 2.28 e 2.29 ).

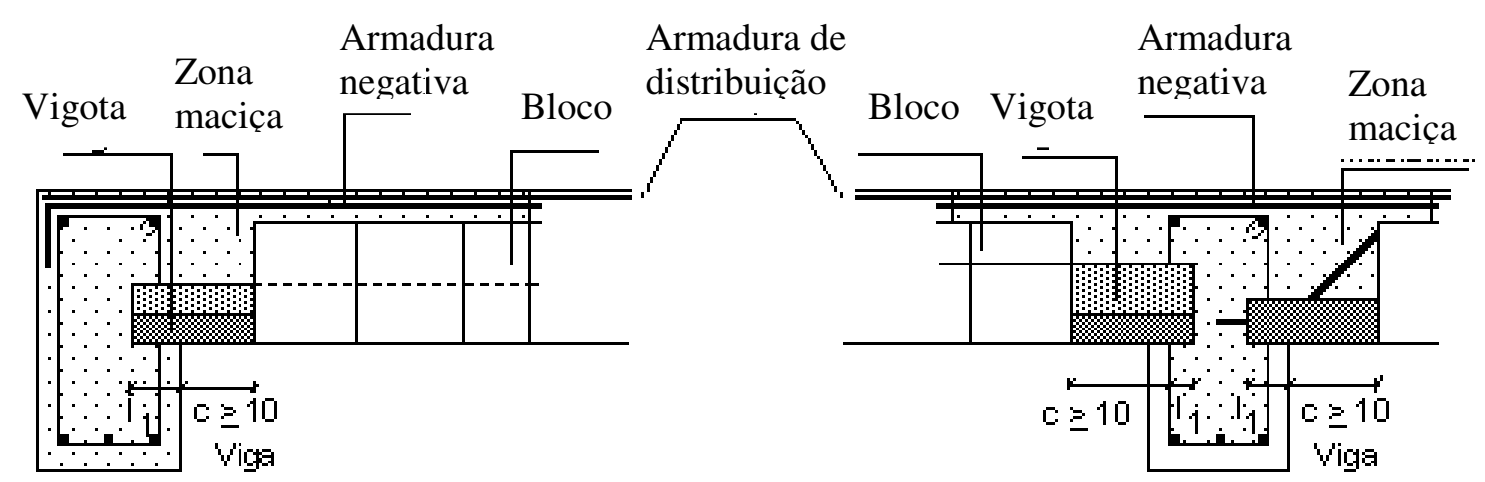

Figura 2.27 - Apoio direto sobre vigas (EF-96: 1997)

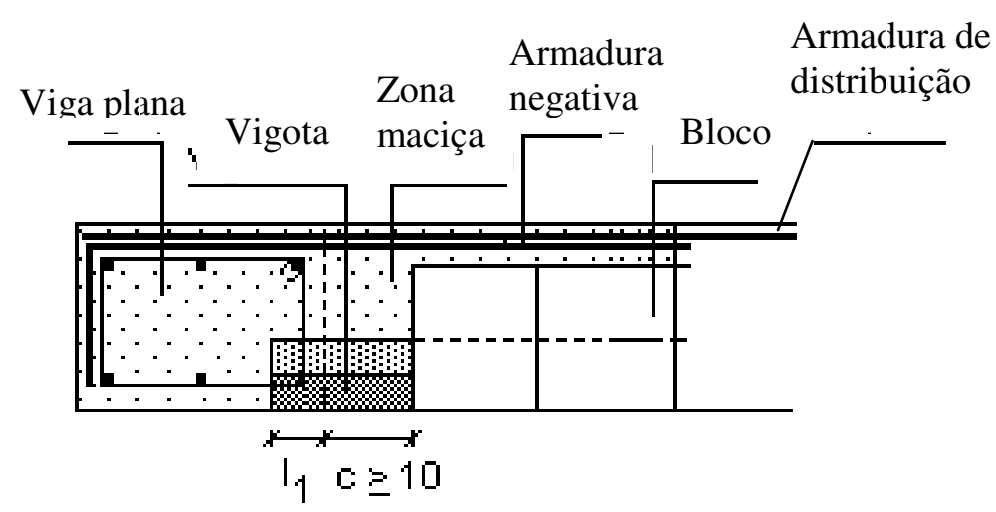

Figura 2.28 - Apoio indireto: ligação por penetração (EF-96: 1997) 


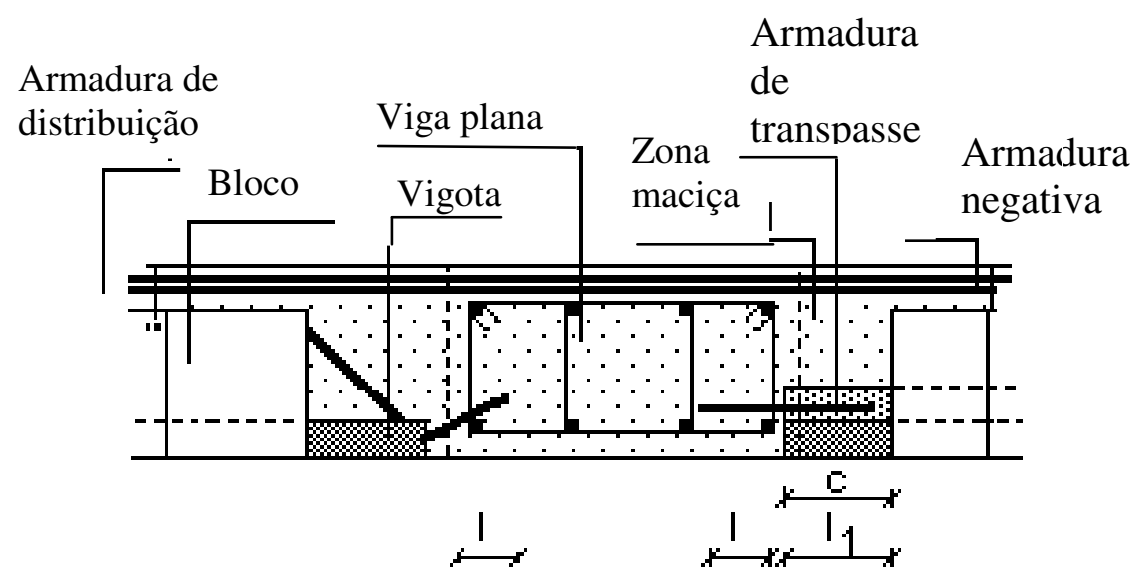

Figura 2.29 - Apoio indireto: ancoragem por prolongação ou transpasse (EF-96:1997)

Quando o comprimento de ancoragem das armaduras não é suficiente, podese colocar uma treliça adicional sobre a vigota treliçada, segundo recomendação do EUROCODE EN 15037-1:2004 (figura 2.30). Nota-se que a altura da laje precisa ser maior que a altura da vigota e a capa de concreto para poder envolver a nova treliça.

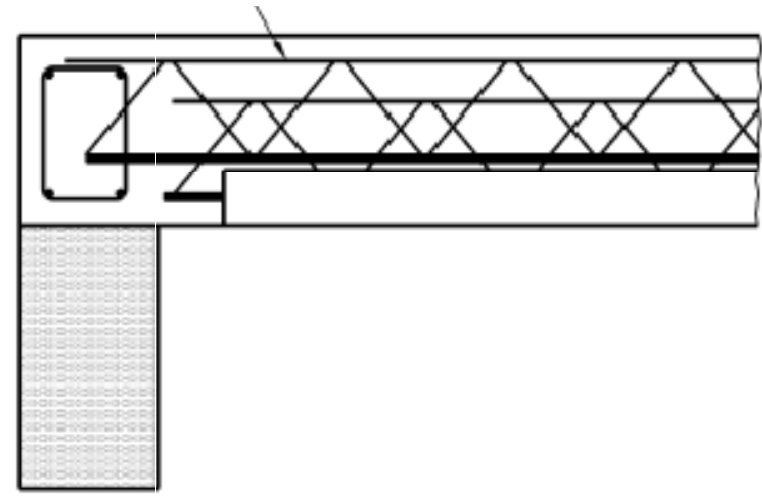

Figura 2.30 - Apoio indireto: treliça adicional sobre a vigota (EN 15037-1:2004)

Deve-se evitar cortar as diagonais da vigota nas proximidades da viga de apoio. Isto pode causar um momento fletor e acarretar na quebra ou fissuração da base de concreto armado da vigota. Na figura 2.31, o caso (a) está correto. Já 
o caso (b) mostra a excentricidade " $e$ " introduzida pela retirada da sinusóide (diagonal) da armação treliçada, não recomendável.

O EUROCODE EN 15037-1:2004 recomenda no anexo D, sobre detalhes dos apoios e ancoragem das armaduras, que o último encontro da sinusóide com a armadura inferior da base de concreto da vigota (ponto 1 da figura 2.32) esteja sobre o apoio ou, no máximo, a $10 \mathrm{~cm}$ da face final da base $(b \leq 10 \mathrm{~cm})$.

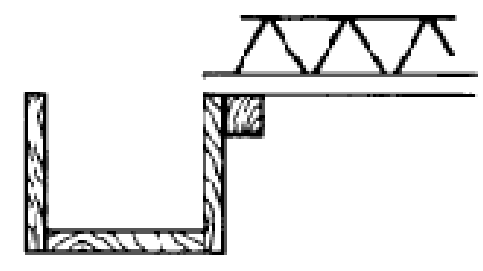

(a)

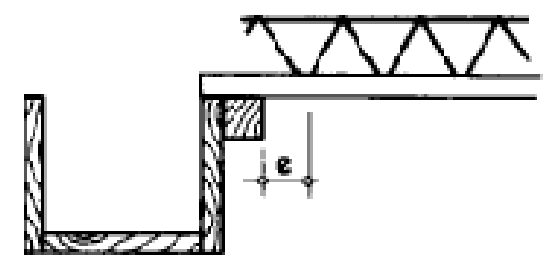

(b)

Figura 2.31 - Apoio da vigota treliçada nas vigas (CEB-FIP, 1998)

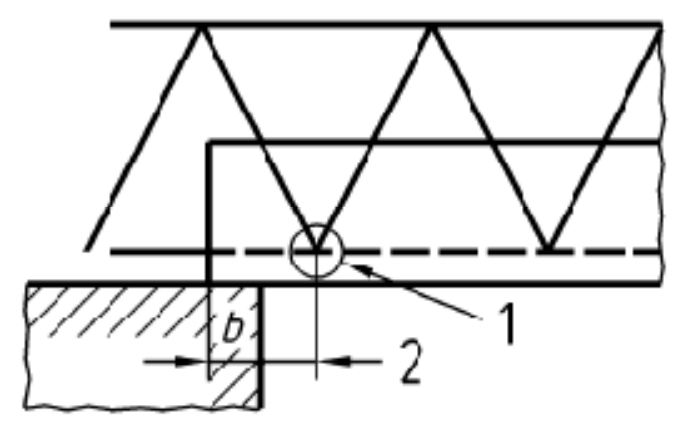

Figura 2.32 - Apoio da vigota treliçada (EUROCODE EN 15037-1:2004, anexo D)

\subsubsection{Cura do concreto}

A cura do concreto moldado no local para as lajes formadas por vigotas treliçadas deve ser feita corretamente, pois evita a formação de fissuras nas primeiras idades do concreto. Em certas obras, há um profissional 
especializado em tecnologia do concreto que se torna responsável por esta etapa do processo. Porém, na maior parte das obras que empregam vigotas treliçadas, este profissional não existe e fica a cargo do engenheiro civil determinar durante quanto tempo deve ser feita a cura e de que forma esta será feita. E não há qualquer recomendação prescrita em normas nacionais a respeito.

Porém, encontra-se no guia de boas práticas do CEB-FIP (1998) para pavimentos pré-moldados, um gráfico (figura 2.33) que mostra o tempo de cura do concreto em função da temperatura e da umidade relativa do ar. A cura do concreto moldado no local para as lajes formadas por vigotas treliçadas deve ser feita o mais rápido possível após a concretagem e sempre evitar "lavar" a face superior da capa do concreto no momento da cura. O CEB-FIP (1998) recomenda aplicar a zona superior adjacente quando estiver ventando. Este gráfico não reflete a realidade brasileira. Apenas foi apresentado aqui para mostrar a preocupação com o tema pelos países europeus.

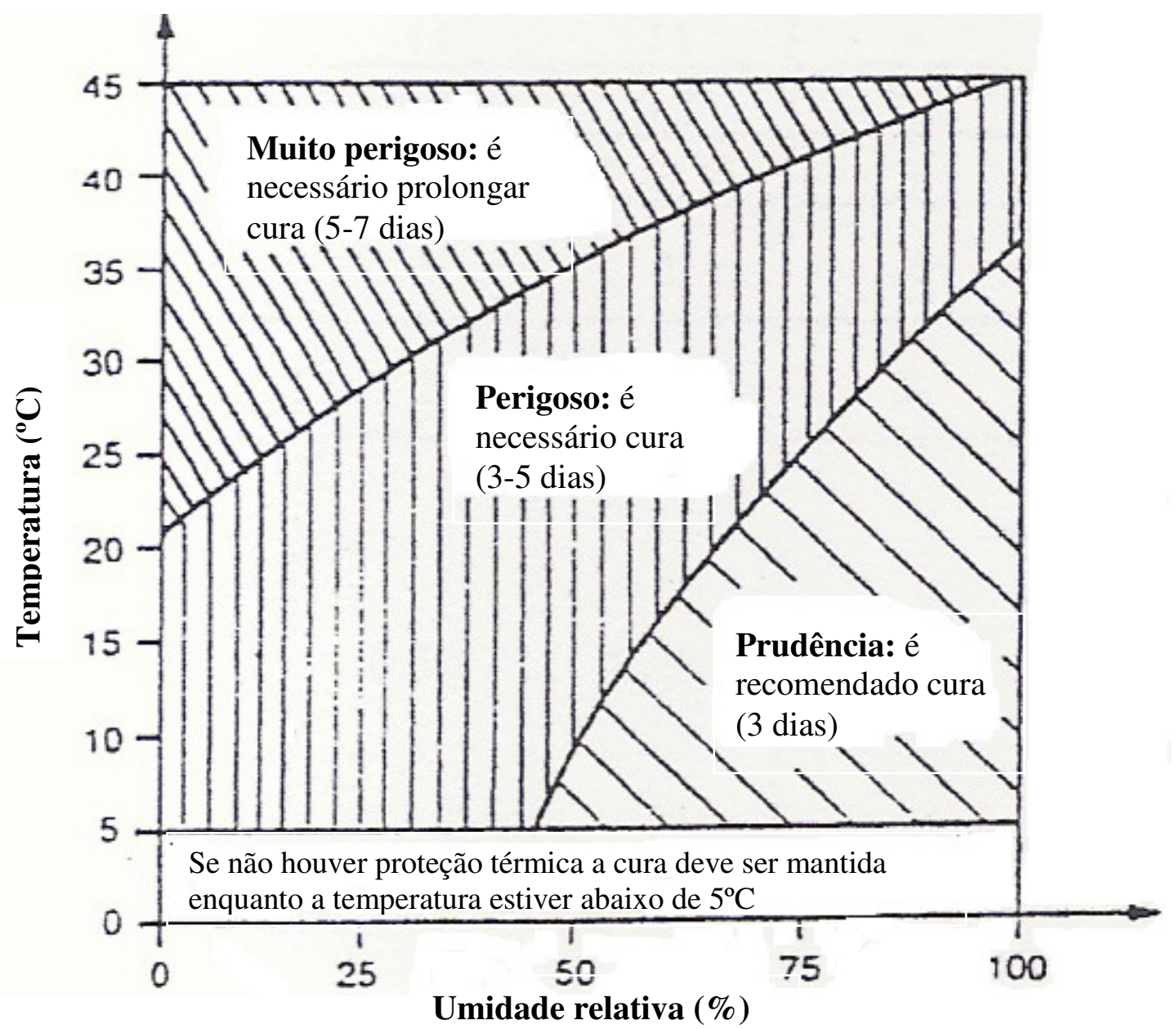

Figura 2.33 - Número de dias para a cura do concreto em função da temperatura e da umidade relativa (adaptado de CEB-FIP, 1998) 





\section{RECOMENDAÇÕES DE PROJETO}

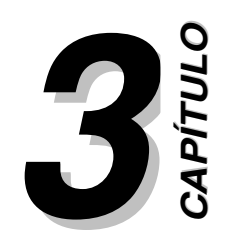

\subsection{CONSIDERAÇÕES INICIAIS}

Com base na revisão bibliográfica e englobando as normas, manuais e guias de lajes pré-moldadas, nacionais e internacionais, as recomendações de projeto abrangem todas as características necessárias das lajes formadas por vigotas treliçadas para realizar um bom projeto.

\subsection{ANÁLISE ESTRUTURAL}

O projeto estrutural das lajes pré-fabricadas formadas por vigotas treliçadas deve seguir o que está preconizado na NBR 6118:2003. A NBR 14859-1:2002 apenas cita quais as premissas de projeto que devem estar contidas no memorial de cálculo e alerta para as verificações dos estados limites de serviço.

\subsubsection{Dimensões das lajes}

A NBR 6118:2003 define as dimensões que devem ser utilizadas para as lajes nervuradas. Estes itens devem balizar a definição da geometria da laje formada por vigotas treliçadas e não são obrigatórias. 
- "A espessura da mesa, quando não houver tubulações horizontais embutidas, deve ser maior ou igual a 1/15 da distância entre nervuras e não menor que $3 \mathrm{~cm}$ ";

- Porém, quando existirem tubulações embutidas de diâmetro máximo $12,5 \mathrm{~mm}$, o valor mínimo absoluto deve ser $4 \mathrm{~cm}$.

- "A espessura das nervuras não deve ser inferior a $5 \mathrm{~cm}$ ";

- "Nervuras com espessura menor que $8 \mathrm{~cm}$ não devem conter armadura de compressão";

- "Lajes com espaçamento entre eixos de nervuras menor ou igual a $65 \mathrm{~cm}$, pode ser dispensada a verificação da flexão da mesa, e para a verificação do cisalhamento da região das nervuras, permite consideração dos critérios de laje";

- "Lajes com espaçamento entre eixos de nervuras entre $65 \mathrm{~cm}$ e 110 $\mathrm{cm}$, exige-se a verificação da flexão da mesa e as nervuras devem ser verificadas ao cisalhamento como vigas; permite-se essa verificação como lajes se o espaçamento entre eixos de nervuras for até $90 \mathrm{~cm}$ e a largura média das nervuras for maior que $12 \mathrm{~cm}$;

- "Lajes nervuradas com espaçamento entre eixos de nervuras maior que $110 \mathrm{~cm}$, a mesa deve ser projetada como laje maciça, apoiada na grelha de vigas, respeitando-se os seus limites mínimos de espessura".

Complementando, a NBR 14859-1:2002 não apresenta limitações em relação à altura da laje, vão de tramo ou limite para a distância entre eixos de nervuras. No entanto, o intereixo mínimo padronizado para cada tipo de vigota é determinado, conforme tabela 3.1. Entretanto, há uma exceção. Se utilizado vigotas treliçadas e a altura total da laje for menor ou igual a $13 \mathrm{~cm}$, permite-se adotar um intereixo mínimo de $40 \mathrm{~cm}$. 
Tabela 3.1 - Intereixos mínimos padronizados (NBR 14859-1:2002)

\begin{tabular}{c|c}
\hline Tipo de vigota & $\begin{array}{c}\text { Intereixos mínimos padronizados } \\
(\mathrm{cm})\end{array}$ \\
\hline $\mathrm{VC}^{1}$ & 33,0 \\
\hline $\mathrm{VP}^{2}$ & 40,0 \\
\hline $\mathrm{VT}^{3}$ & $\mathbf{4 2 , 0}$ \\
\hline
\end{tabular}

Notas: ${ }^{1}$ vigota de concreto armado; ${ }^{2}$ vigota de concreto protendido; ${ }^{3}$ vigota treliçada

As alturas das lajes estão padronizadas e devem ser compostas da seguinte forma: sigla (LC, LP ou LT) do tipo de vigota utilizado; altura total (h) da laje; altura do enchimento $\left(h_{e}\right)$;símbolo de "+" e altura da capa $\left(h_{c}\right)$. Os valores das alturas devem ser expressos em centímetros. A tabela 3.2 mostra alguns exemplos.

Tabela 3.2 - Altura padronizada da laje (NBR 14859-1:2002)

\begin{tabular}{c|c}
\hline Laje & Exemplos \\
\hline LC h $\left(h_{e}+h_{c}\right)$ & LC $12(8+4)$ \\
\hline LP h $\left(h_{e}+h_{c}\right)$ & LP 10 (7+3) \\
\hline LT $h\left(h_{e}+h_{c}\right)$ & LT 20(16+4) \\
\hline
\end{tabular}

A norma espanhola EF-96 (1997) "Instruções para o projeto e execução de lajes unidirecionais de concreto armado ou protendido", trata também de vigotas pré-moldadas. Tal norma é aplicável a lajes unidirecionais que cumprem as seguintes especificações:

- Espessura total da laje igual ou inferior a $50 \mathrm{~cm}$;

- Vão de tramo igual ou inferior a 10m;

- Distância entre eixos de nervuras menor que 100 cm; 


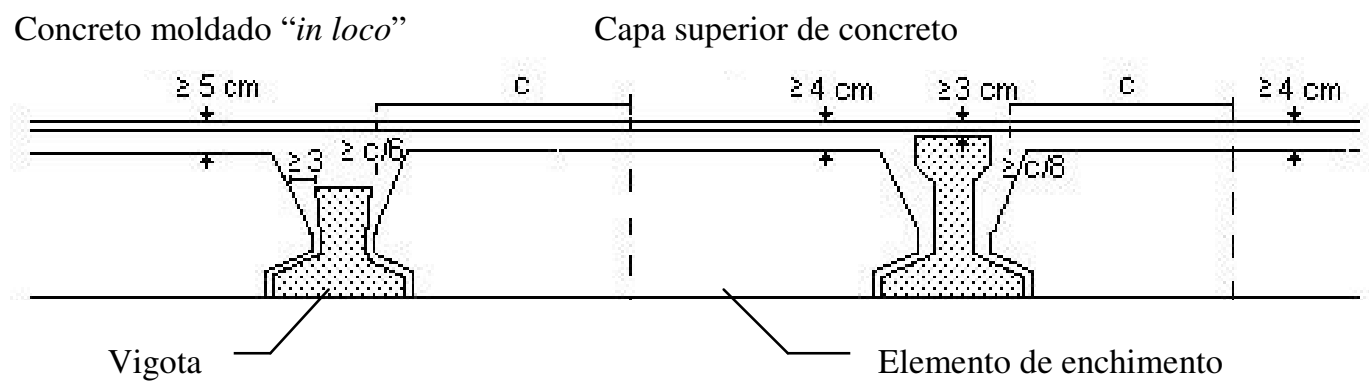

Figura 3.1 - Espessuras mínimas das lajes formadas por vigotas pré-moldadas (EF-96: 19.97)

\subsubsection{Elementos de enchimento}

Os elementos de enchimento, segundo a NBR 14859-1 (2002), devem ter resistência para uma carga mínima de $1,0 \mathrm{kN}$, suficiente para suportar as ações provenientes da montagem e concretagem da laje. Já a EF-96 (1997) especifica os mesmos $1,0 \mathrm{kN}$ de força para os elementos de enchimento resistirem e repartida uniformemente em uma placa de $200 \mathrm{~mm} \times 75 \mathrm{~mm}$ x $25 \mathrm{~mm}$, situada na zona mais desfavorável do elemento. O seu comportamento de reação ao fogo deve alcançar ao menos uma classificação $\mathrm{M}-1$ de acordo com a norma UNE 23.727/90. Existe uma norma específica que trata apenas dos blocos de enchimento, o EUROCODE EN 15037-2 (Precast concrete products - Beam-andblock floor systems - Part 2: Blocks, 2004) e controla a qualidade dos blocos de concreto, cerâmico e EPS.

Para a EF-96 (1997), a espessura da capa de concreto moldada no local deve ter espessura mínima de $4 \mathrm{~cm}$ para elementos de enchimento de cerâmica ou concreto (figura 3.1). O mínimo para a NBR 14859-1 (2002) é de $3 \mathrm{~cm}$.

\subsubsection{Pré-dimensionamento da altura da laje}

Não há nenhuma recomendação na NBR 6118:2003 para adoção prévia de altura de lajes. Porém na NBR 6118:1980, há uma recomendação, em função do tipo de vinculação $\left(\Psi_{2}\right)$, vãos teóricos da laje e tensão na armadura para 
solicitação de cálculo $\left(\Psi_{3}\right)$. Nela, encontra-se o valor da altura útil da laje (d) baseada nas características citadas anteriormente. É válida para lajes maciças retangulares e dispensava o cálculo de flechas quando a altura útil "d" fosse maior que o calculado.

Outra indicação é a recomendação de Carvalho e Figueiredo Filho (2005), extraída da página 92, tabela 2.5, em função da carga aplicada e do vão livre. A tabela 3.3 mostra qual a altura de laje a ser adotada para cada valor de carga uniformemente distribuída na laje.

A norma espanhola EF-96 (1997) apresenta uma expressão para o cálculo da altura da laje formada por vigotas treliçadas pré-moldadas e válida apenas para vãos teóricos menores que $7 \mathrm{~m}$ e sobrecargas menores ou igual a 4 $\mathrm{kN} / \mathrm{m}^{2}$. Se a altura da laje adotada for maior que a calculada pela expressão 3.1 não é necessário calcular a flecha.

Tabela 3.3 - Escolha da altura da laje em função da carga e vão livre máximo (CARVALHO e FIGUEIREDO FILHO, 2005)

\begin{tabular}{c|c|c|c}
\hline $\begin{array}{c}\text { Altura } \\
\text { total da } \\
\text { laje }\end{array}$ & $\begin{array}{c}\text { Peso } \\
\text { próprio }\end{array}$ & $\begin{array}{c}(\mathbf{g}+\mathbf{q})<\mathbf{1 , 0} \\
\mathbf{k N} / \mathbf{m}^{2} \text { (forro) }\end{array}$ & $\begin{array}{c}\mathbf{2 , 0} \mathbf{k N} / \mathbf{m}^{2}<(\mathbf{g}+\mathbf{q})<5,0 \\
\mathbf{k N} / \mathbf{m}^{2}\end{array}$ \\
\cline { 3 - 4 } & & $3,5 \mathrm{~m}$ & - \\
\hline $\mathbf{1 0}$ & 1,10 & $5,0 \mathrm{~m}$ & $4,5 \mathrm{~m}$ \\
\hline $\mathbf{1 2}$ & 1,41 & $6,0 \mathrm{~m}$ & $5,5 \mathrm{~m}$ \\
\hline $\mathbf{1 4}$ & 1,50 & - & $>5,5 \mathrm{~m}$ \\
\hline $\begin{array}{c}\mathbf{1 6} \text { ou } \\
\text { maior }\end{array}$ & $>1,61$ & - & \\
\hline
\end{tabular}

OBS: Valores de peso próprio para intereixo de $50 \mathrm{~cm}$, capa de $3 \mathrm{~cm}$ e material de enchimento cerâmico.

$$
h=\delta_{1} \cdot \delta_{2} \cdot L / C
$$

sendo $h=$ : altura total da laje em metros;

$\delta_{1}=$ fator que depende da carga total e que têm o valor de $\sqrt{q / 7}$, sendo $q$ a carga total em $\mathrm{kN} / \mathrm{m}^{2}$;

$\delta_{2}=$ fator que tem o valor de $\sqrt[4]{L / 6}$, sendo $L$ o vão da laje em metros; 
$L=$ vão teórico da laje em metros;

$C=$ coeficiente cujo valor está descrito na tabela 3.4.

Tabela 3.4 - Coeficientes C (EF-96, 1997)

\begin{tabular}{c|l|c|c|c}
\hline \multirow{2}{*}{ Coeficientes C } & \multicolumn{3}{c}{ Tipo do vão } \\
\cline { 3 - 5 } \multicolumn{2}{c|}{} & Isolado & Extremo & Interno \\
\hline \multirow{3}{*}{\begin{tabular}{c} 
Vigota de concreto $\begin{array}{c}\text { de } \\
\text { armado }\end{array}$ \\
\cline { 2 - 5 }
\end{tabular}} & \begin{tabular}{l} 
divisórias \\
\cline { 2 - 5 }
\end{tabular} & 18 & 22 & 25 \\
\cline { 2 - 5 } & telhados paredes & 17 & 21 & 24 \\
\hline
\end{tabular}

Há também valores de "C" para lajes formadas por vigotas de concreto protendido e para painéis alveolares, mas não foram listados aqui, pois foge ao tema central do trabalho.

Apenas como exemplo foi feito um cálculo de altura de laje formada por vigotas treliçadas pré-moldadas necessária para um vão de 4,0m e uma carga total de $4,0 \mathrm{kN} / \mathrm{m}^{2}$. Os valores encontrados para as alturas de lajes $(\mathrm{em} \mathrm{cm}$ ) estão descritos na tabela 3.5. Apenas para reforçar e seguir o que realmente está disposto na EF-96:1997, a altura da laje a ser adotada para que não seja necessária a verificação de flechas limites é um valor maior que o calculado, e não igual.

Tabela 3.5 - Valores de altura de laje $\left(\mathrm{em} \mathrm{cm}\right.$ ) para vão de $4,0 \mathrm{~m}$ e carga de $4,0 \mathrm{kN} / \mathrm{m}^{2}$

\begin{tabular}{|c|c|c|c|c|}
\hline \multirow{2}{*}{\multicolumn{2}{|c|}{ Altura da laje $(\mathrm{em} \mathrm{cm})$}} & \multicolumn{3}{|c|}{ Vão } \\
\hline & & \multirow{2}{*}{$\begin{array}{c}\text { Isolado } \\
15 \\
\end{array}$} & \multirow{2}{*}{$\begin{array}{c}\text { Extremo } \\
12 \\
\end{array}$} & \multirow{2}{*}{$\begin{array}{c}\text { Interno } \\
11\end{array}$} \\
\hline \multirow{3}{*}{$\begin{array}{c}\text { Vigota de concreto } \\
\text { armado }\end{array}$} & $\begin{array}{l}\text { com } \\
\text { divisórias }\end{array}$ & & & \\
\hline & com paredes & 16 & 13 & 11 \\
\hline & telhados & 14 & 11 & 10 \\
\hline
\end{tabular}

O anexo G do EUROCODE EN 15037-1:2004 salienta que o conjunto da vigota com a capa de concreto moldada no local pode atuar como um diafragma rígido se a espessura da capa for, pelo menos de $4 \mathrm{~cm}$, quando se situa acima do material de enchimento, e pelo menos de $3 \mathrm{~cm}$, quando se situa acima da vigota de concreto. Além disso, deverá apresentar uma tela contínua 
eletrossoldada, completamente ancorada nos apoios, com seção transversal na direção perpendicular aos vãos da vigota, de $1,0 \mathrm{~cm}^{2} / \mathrm{m}$ e na direção paralela de, pelo menos, $0,5 \mathrm{~cm}^{2} / \mathrm{m}$. Para regiões de grande atividade sísmica estes valores mínimos devem ser majorados em $40 \%$. Para todos os casos, o comprimento de ancoragem deve aumentar em $30 \%$.

A distribuição das cargas melhora muito também com o aumento da espessura relativa da capa e laje. Carvalho e Figueiredo Filho (2005) demonstram isso em uma investigação composta de sete casos que variam características das lajes como altura, condição de contorno, fissuração da capa etc. Entre dois casos que são semelhantes e muda apenas a espessura relativa da capa e da laje, tem-se que a laje com espessura da capa maior obteve cerca de $60 \%$ menos carga para as vigas secundárias. A vulnerabilidade é menor ao colapso progressivo.

\subsubsection{Armaduras mínimas}

Segundo a EF-96:1997, as armaduras longitudinais inferiores de cada vigota de concreto armado deve possuir, ao menos, duas barras, e sua seção $A_{s}$ será tal que respeite as seguintes condições (figura 3.2):

$$
A_{s} \geq 0,08 \cdot \frac{b_{w} \cdot h \cdot f_{c d}}{f_{y d}}
$$

e

$$
A_{s} \geq \beta . b_{w}
$$

sendo $b_{w}=$ largura mínima da nervura;

$h=$ altura total da laje;

$\beta=$ coeficiente que vale 0,003 para o aço CA-50 e CA-60 (já que este último não há referência na EF-96. 


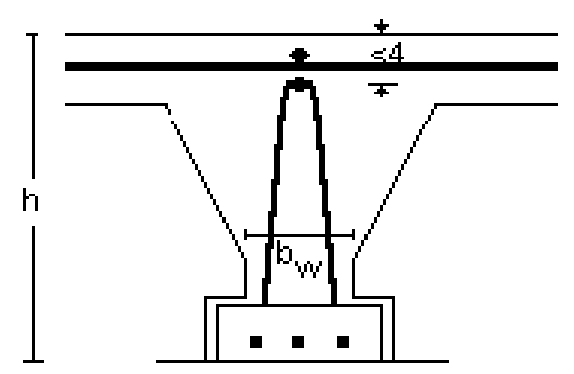

Figura 3.2 - Largura mínima da nervura (EF-96:1997)

No mínimo um terço da armadura do meio do vão deve ser prolongada até os apoios, segundo a EF-96:1997. Este valor passa a 50\% quando se trata da NBR 14859-1:2004. A ancoragem da armadura nos apoios, principalmente os externos, deve requerer uma atenção especial (EL DEBS, 2000). Tanto que a EF-96:1997 estabelece uma largura mínima de $10 \mathrm{~cm}$ para a zona maciça de concreto, como já visto nas figuras 2.22 e 2.23 do capítulo 2 do presente trabalho, tanto em apoios interiores quanto exteriores.

Segundo a EF-96:1997, com relação à armadura de distribuição, presente na capa de concreto moldado no local, deve apresentar, no mínimo, barras de 4,2 mm de diâmetro dispostas nas duas direções e espaçadas de $35 \mathrm{~cm}$, no máximo. O cálculo da seção desta armadura $\left(\mathrm{em} \mathrm{cm}^{2} / \mathrm{m}\right)$ nas duas direções deve satisfazer as seguintes condições:

- Na direção perpendicular às nervuras:

$$
A_{s} \geq 50 \cdot \frac{h_{0}}{f_{y d}}
$$

- Na direção paralela às nervuras:

$$
A_{s} \geq 25 \cdot \frac{h_{0}}{f_{y d}}
$$

sendo $h_{0}=$ espessura mínima da capa de concreto, em cm;

$f_{y d}=$ tensão de cálculo de escoamento do aço, em N/mm²;

$A_{s}=$ área de armadura, em $\mathrm{cm}^{2} / \mathrm{m}$. 
Já a NBR 14859-1:2002 apresenta uma tabela (tabela 3.6) em que determina a área e quantidade mínima de barras de aço, de acordo com o seu tipo.

Tabela 3.6 - Área mínima e quantidade de armadura de distribuição (NBR 14859-1:2002)

\begin{tabular}{cccc}
\hline \multirow{2}{*}{ Aço } & Área & \multicolumn{2}{c}{ Número de barras $/ \mathrm{m}$} \\
\cline { 3 - 4 } & mínima & $\Phi 5,0 \mathrm{~mm}$ & $\Phi 6,3 \mathrm{~mm}$ \\
\hline CA-25 & $0,9 \mathrm{~cm}^{2} / \mathrm{m}$ & 5 & 3 \\
\hline $\begin{array}{c}\text { CA-50, CA-60 e } \\
\text { tela soldada }\end{array}$ & $0,6 \mathrm{~cm}^{2} / \mathrm{m}$ & 3 & 3 \\
\hline
\end{tabular}

A função desta armadura é solidarizar as vigotas e distribuir transversalmente cargas localizadas. Além de distribuir a fissuração decorrente da retração e variações de temperatura, há também um ganho de resistência no plano das vigotas, frente às ações horizontais que atuam na estrutura EF-96: 1997. Para cargas concentradas mais relevantes ou uma espessura da capa maior que $6 \mathrm{~cm}$, a EF-96:1997 sugere um estudo especial da armadura nesta capa.

As armaduras negativas podem ser definidas, de acordo com a EF96:1997, de forma simplificada, quando a sobrecarga de utilização não for maior que um terço da carga total nem que $3 \mathrm{kN} / \mathrm{m}^{2}$. Em apoios de vão exterior, 0 comprimento da armadura é a base da viga na direção horizontal mais um décimo do vão; em apoios de vão exterior com balanço, o comprimento será o vão do balanço mais um décimo do vão exterior. Para apoios interiores, os valores são o maior entre 0,3 do vão exterior adjacente ou 0,25 do vão interior adjacente, para cada lado.

A distribuição de cargas concentradas situadas no centro de uma vigota interior, ou lineares paralelas as mesmas, na ausência de cálculos mais precisos, pode-se obter de forma simplificada multiplicando a carga "F" pelos coeficientes fornecidos pela tabela 3.7. A figura 3.3 ilustra as vigotas e sua proximidade da carga concentrada. 


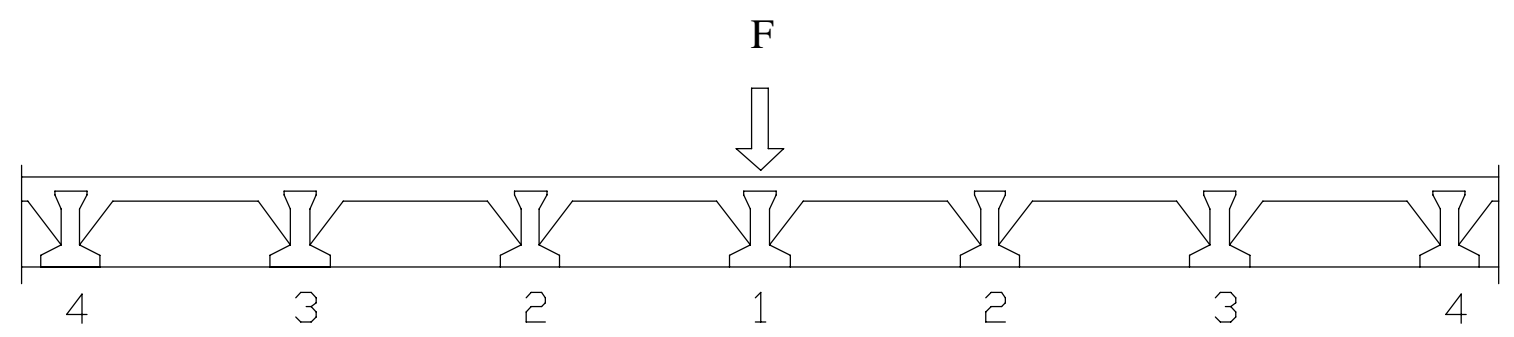

Figura 3.3 - Distribuição transversal de cargas concentradas ou lineares (EF-96:1997)

Tabela 3.7 - Coeficientes de distribuição das cargas concentradas ou lineares (EF96:1997)

\begin{tabular}{c|c|c|c|c}
\hline Vigota & 1 & 2 & 3 & 4 \\
\hline Coeficiente & 0,30 & 0,25 & 0,15 & 0 \\
\hline
\end{tabular}

Ainda segundo a EF-96 (1997), no caso da capa de concreto ser moldada no local, deve-se armá-la para resistir a um momento de:

- 0,3 $p_{d}$, para carga linear;

$-0,125 \cdot P_{d}$, para carga concentrada.

sendo $\quad P_{d}$ : carga concentrada de cálculo, em $\mathrm{kN}$;

$p_{d:}$ carga linear de cálculo, em $\mathrm{kN} / \mathrm{m}$ de vigota.

Esta armadura deve se estender até uma distância $L / 4$ na direção das vigotas a partir da carga concentrada e o mesmo comprimento a partir das extremidades da região da carga em caso de carga linear. Na outra direção, perpendicular às vigotas, a armadura deve prolongar-se até a vigota 4 das figuras 3.4 e 3.5 . 


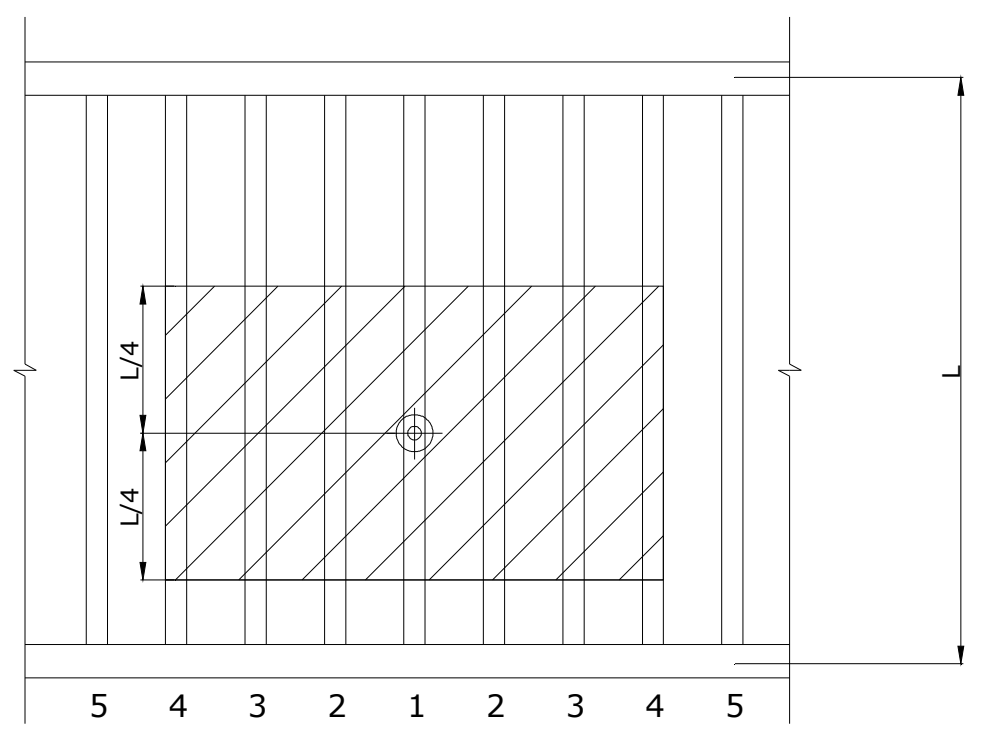

Figura 3.4 - Área necessária da armação da capa para cargas concentradas (EF-96: 1997)

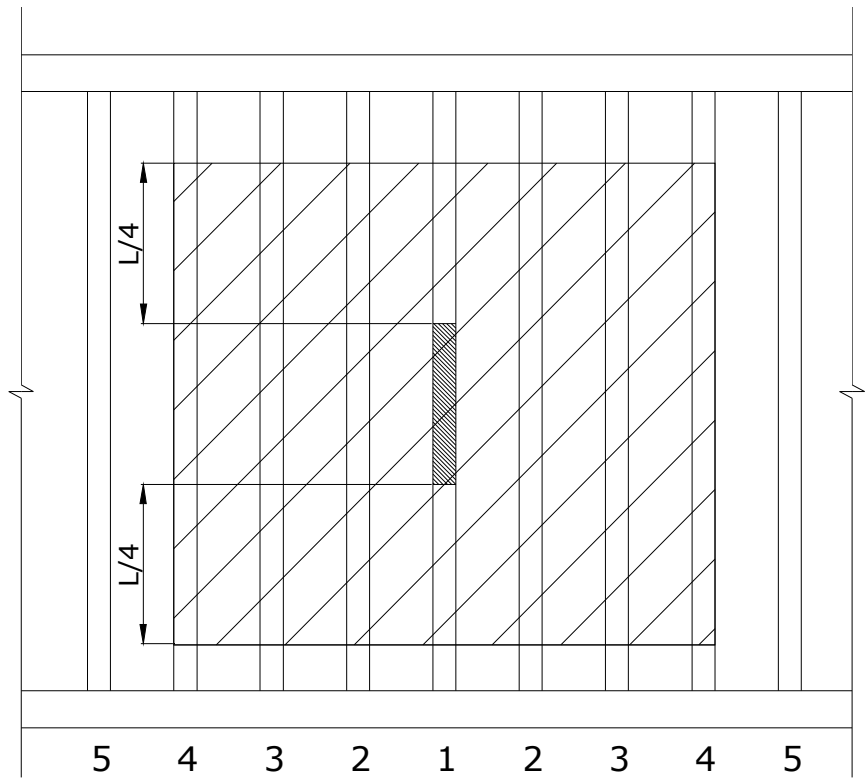

Figura 3.5 - Área necessária da armação da capa para cargas lineares (EF-96: 1997)

\subsection{DIMENSIONAMENTO}

A verificação quanto ao estado limite de serviço é o ponto crítico para o dimensionamento de lajes formadas por vigotas treliçadas. 


\subsubsection{Estado Limite de Serviço (E.L.S.)}

Após a escolha da altura da laje e de posse das cargas atuantes recomenda-se verificar a estrutura em serviço. Avaliar os deslocamentos e vibrações, além da abertura de fissuras e outras são algumas das verificações que podem ser feitas. Começando pelos deslocamentos, que são fundamentais na escolha da altura da laje. Após análise linear e não-linear, verifique se ultrapassa os limites preconizados pela NBR 6188:2003.

Quanto à verificação das vibrações excessivas, se houver problemas, leva-se em conta que a utilização de blocos de concreto ou cerâmico como elementos de enchimento ou invés de EPS ajuda a diminuir os efeitos da vibração, pois possuem um peso próprio maior que os blocos em EPS. Além disso, a espessura do contrapiso e do revestimento devem ajudar também a combater as vibrações, mas não há ainda pesquisas realizadas sobre o tema. As cargas variáveis devem ser adotadas como $0,50 \mathrm{kN} / \mathrm{m}^{2}$ para escritórios e 0,25 para residências na verificação do ELS-VE para obter um projeto mais racional, como descrito no capítulo 2.

\subsubsection{Estado Limite Último (E.L.U.)}

É a última verificação a ser realizada. Como não é o mais crítico no dimensionamento das lajes, pode-se deixar para verificar os momentos fletores e forças cortantes no fim. Alerta deve ser feita para a utilização de tabelas fornecidas por fabricantes de lajes já que são elaboradas para elementos biapoiados. 


\section{.}





\subsection{CONSIDERAÇÕES INICIAIS}

O exemplo a seguir foi adaptado pelo autor a partir de um projeto originalmente concebido em alvenaria estrutural de blocos vazados de concreto e lajes maciças em concreto armado. O objetivo é elucidar algumas dúvidas e questões freqüentes relativas ao cálculo de lajes formadas por vigotas treliçadas pré-moldadas. Foi utilizado o software dos Sistemas TQS, elaborado pela TQS Informática Ltda., versão 16.4, de cálculo estrutural para a obtenção de esforços solicitantes e análise dos estados limites de serviço das lajes. As recomendações de projeto fornecidas no capítulo 3 foram adotadas e seguidas na formulação do exemplo e serão citadas ao longo do capítulo.

O exemplo proposto nasceu de um projeto de alvenaria estrutural no qual se utilizou blocos vazados de concreto com $14 \mathrm{~cm}$ de espessura. As lajes inicialmente eram maciças e há algumas paredes não-estruturais apoiadas diretamente sobre as lajes, como se pode observar na figura 4.1.

O edifício possui quatro pavimentos-tipo com dupla simetria e distância de piso a piso de 2,70m. Havia uma escada na parte central da edificação, mas por comodidade não será considerada no cálculo. Dessa forma, tem-se laje em substituição ao vão da escada.

O pavimento deste exemplo é composto por lajes formadas de vigotas com armação treliçada e elementos de enchimento em EPS. A planta de formas, sem escala, está representada na figura 4.2. Há vãos variando de 2 a 4 metros (típico para obras correntes) e as lajes têm $10 \mathrm{~cm}$ de espessura, sendo $7 \mathrm{~cm}$ da 
vigota e $3 \mathrm{~cm}$ da capa de concreto. $O$ valor do intereixo é de $42 \mathrm{~cm}$. A seção típica da laje está desenhada na figura 4.4.

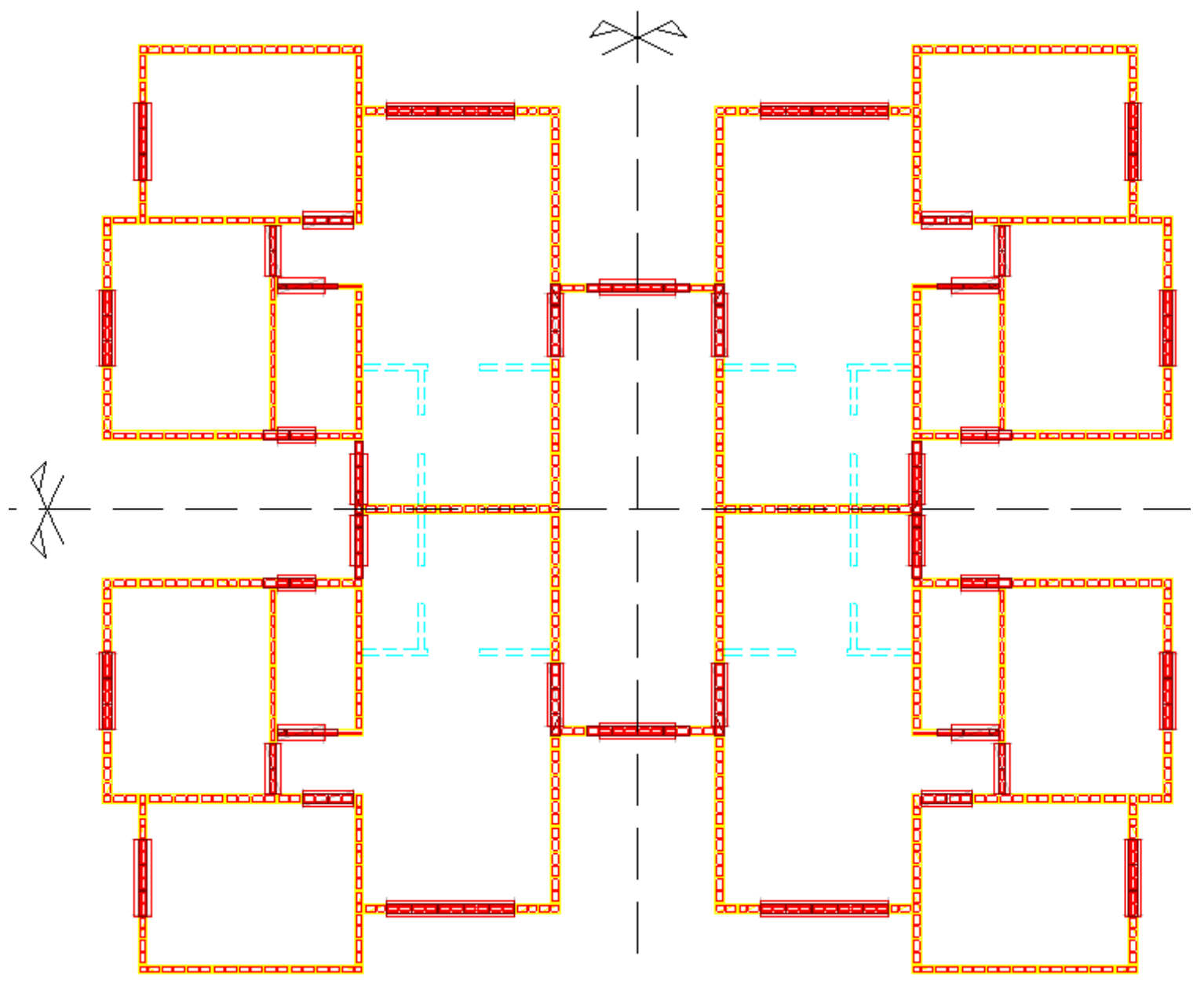

Figura 4.1 - Pavimento em alvenaria estrutural com lajes maciças de concreto

Os demais dados a respeito do exemplo são:

- Concreto estrutural da capa: $f_{\mathrm{ck}}=25 \mathrm{MPa}$

- Concreto estrutural da base da vigota: $f_{\mathrm{ck}}=25 \mathrm{MPa}$

- Módulo de elasticidade inicial do concreto: $\mathrm{E}_{\mathrm{ci}}=28000 \mathrm{MPa}$

- Revestimento: $\mathrm{g}=1,0 \mathrm{kN} / \mathrm{m}^{2}$

- Sobrecarga de utilização: $q=2,0 \mathrm{kN} / \mathrm{m}^{2}$

- Elemento de enchimento de EPS: $\gamma=0,17 \mathrm{kN} / \mathrm{m}^{3}$

- Aço CA-50 com $\mathrm{f}_{\mathrm{yk}}=500 \mathrm{MPa}$ e CA-60 com f $\mathrm{yk}=600 \mathrm{MPa}$ 


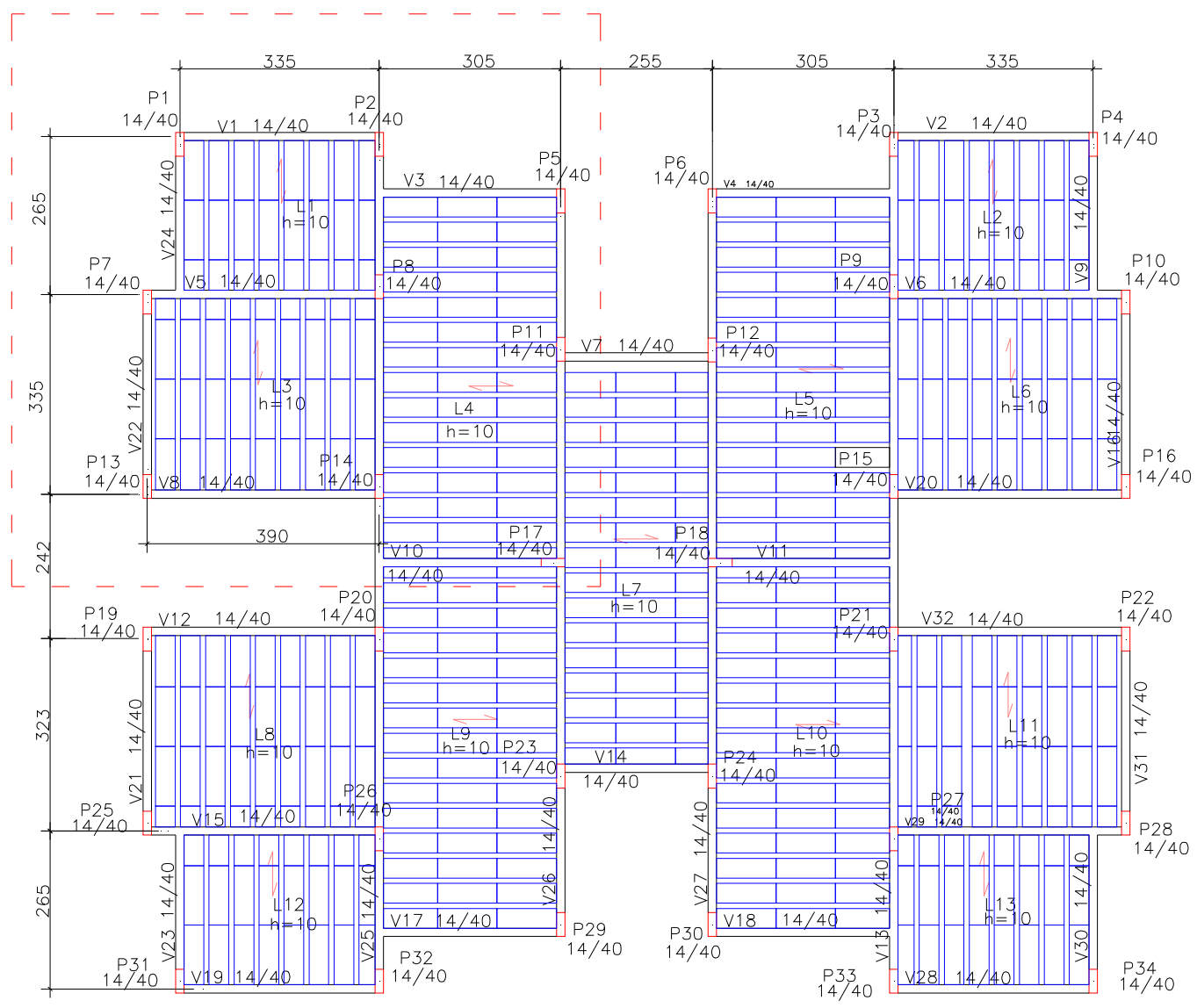

Figura 4.2 - Formas do pavimento a ser analisado (sem escala)

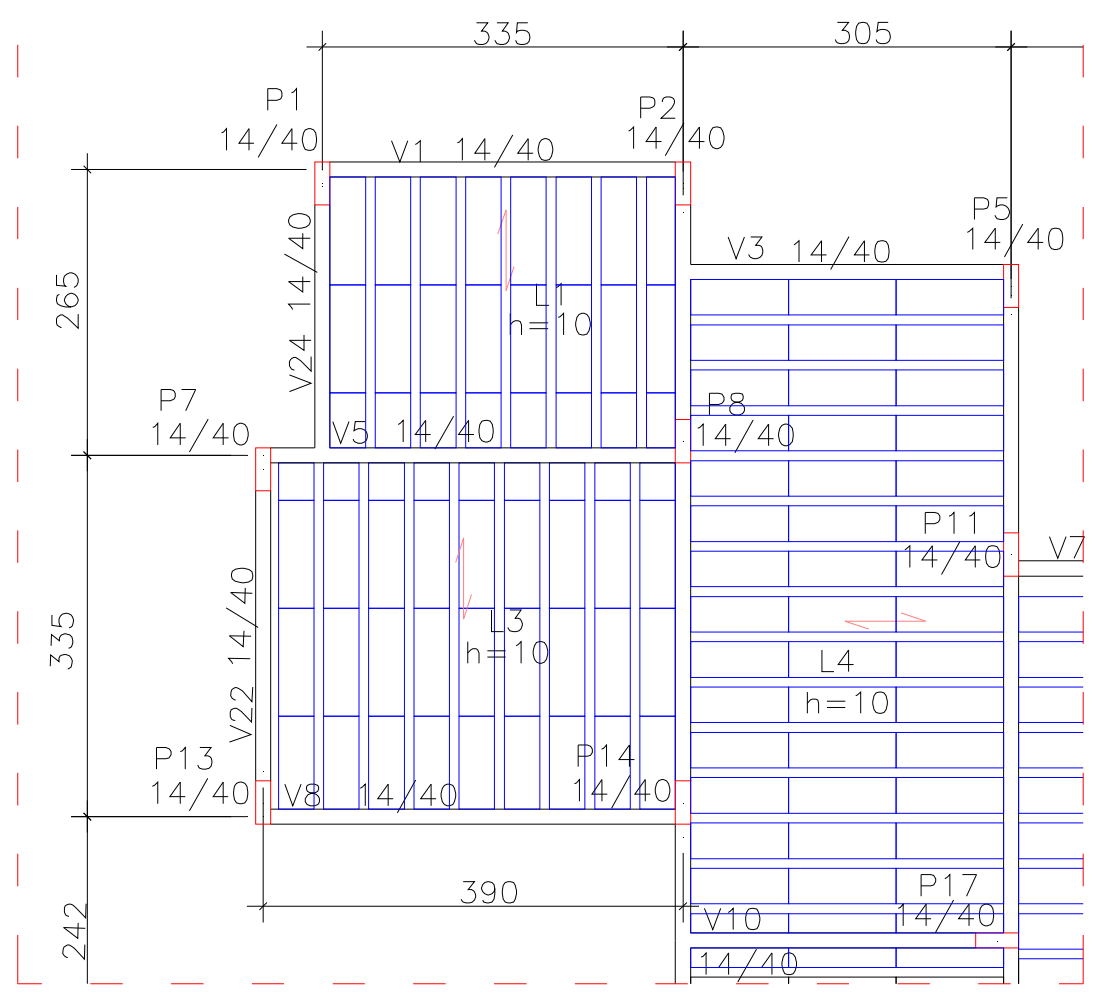

Figura 4.3 - Lajes a serem analisadas (sem escala) 


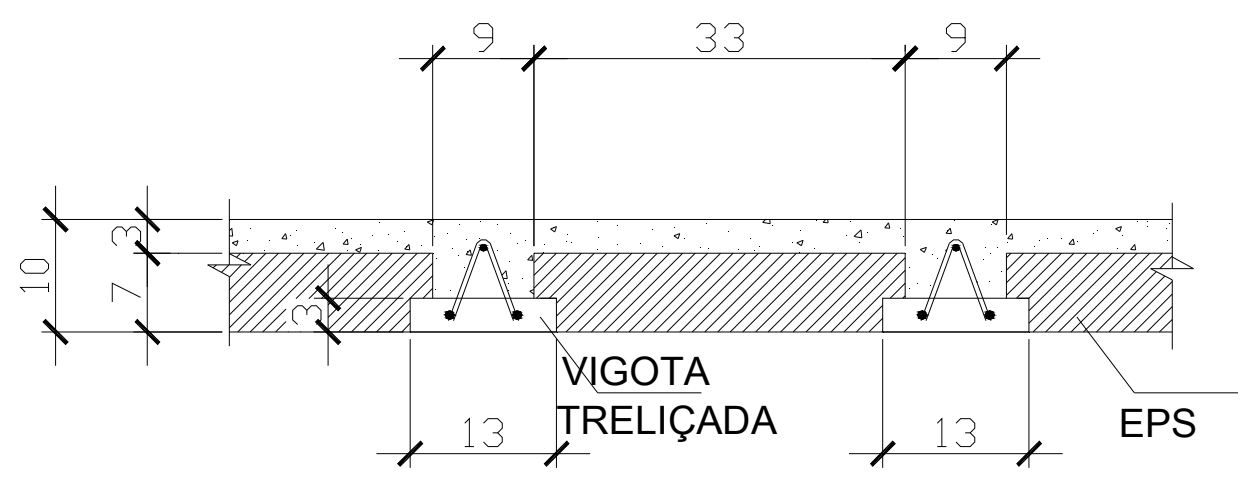

Figura 4.4 - Seção típica da laje

Este exemplo é um caso típico de projeto de lajes formadas por vigotas treliçadas dito convencional. Os problemas que aparecem nas verificações e dimensionamento são discutidos e complementados ao longo do capítulo.

\subsection{JUSTIFICATIVAS PARA A GEOMETRIA ADOTADA}

A escolha da altura da laje é feita com muita freqüência hoje com o auxilio de tabelas de fabricantes de lajes. Para um pré-dimensionamento o autor seguiu a recomendação de Carvalho e Figueiredo Filho (2005) descrita no capítulo 3.

Optou-se por $3 \mathrm{~cm}$ de espessura para a capa de concreto, o mínimo permitido pela NBR 14859-1:2002. A recomendação da EF-96 (1997) é de $4 \mathrm{~cm}$, no mínimo. É feito aqui o que normalmente se faz em projetos de lajes formadas por vigotas treliçadas. Muitos não adotam nervuras transversais e nem regiões maciças próximas aos apoios, obrigatória pela EF-96 (1997). Isto trará conseqüências que serão expostas e discutidas no decorrer do capitulo.

\subsection{ANÁLISE ESTRUTURAL}

A análise estrutural das lajes é feita utilizando a analogia de grelha e serão calculados os deslocamentos das lajes em uma análise linear e outra nãolinear, para podermos comparar os valores obtidos. Esta análise não-linear 
corresponde a não-linearidade física (NLF). É utilizado o utilizado o software dos Sistemas TQS para isso. Os cálculos estão presentes no item 4.7 deste capítulo

O desenho da grelha formada por barras e nós está representado na figura 4.5.

Alguns parâmetros definidos nos critérios do programa devem ser aqui descritos, pois são muito importantes para o entendimento da resolução do exemplo.

$\mathrm{Na}$ análise não-linear o carregamento total é subdividido em incrementos de carga. A rigidez dos elementos é corrigida a cada novo incremento assim que a fissuração se propaga. Foram adotados para este exemplo 20 incrementos de carga. A armadura deve ser previamente conhecida para que os cálculos sejam efetuados. O momento de inércia equivalente é calculado conforme expressão de Branson presente na NBR 6118:2003. É considerada a resistência à tração entre fissuras, conhecida como "tension stiffining", e a fluência do concreto.

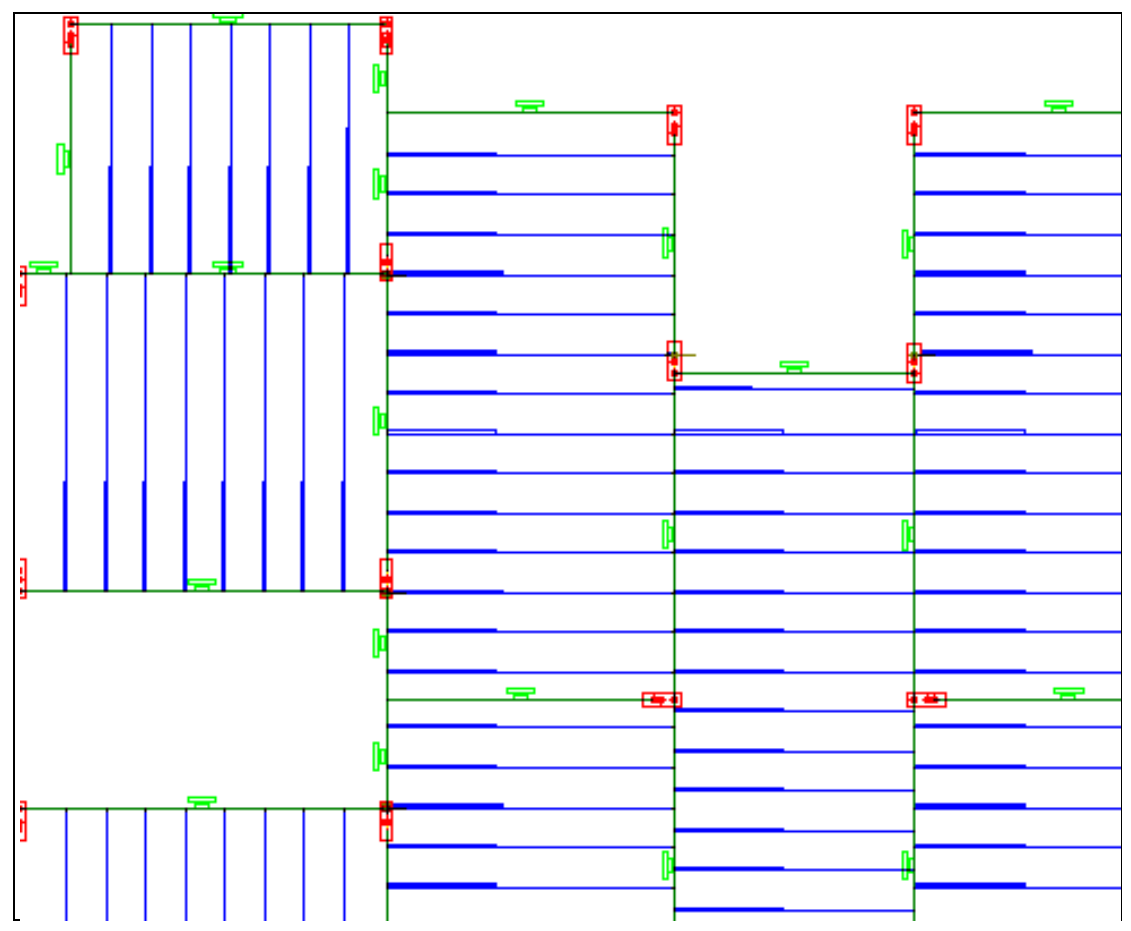

Figura 4.5 - Barras da grelha gerada pelo TQS 
Não foi considerada no cálculo a rigidez à torção das vigotas.

Todos os deslocamentos obtidos são referentes ao carregamento do peso próprio, carga permanente e $30 \%$ da sobrecarga. Esta combinação é a combinação quase permanente de serviço (CQP), onde todas as ações variáveis são consideradas com seus valores quase permanentes. Assim, serão multiplicadas pelo coeficiente $\Psi_{2}$ da NBR 6118:2003 presente no item 11.7.1, conforme ilustra a tabela 4.1 abaixo

Tabela 4.1 - Valores do coeficiente $Y_{\mathfrak{f} 2}$ (NBR 6118:2003)

\begin{tabular}{|c|c|c|c|c|}
\hline \multirow{2}{*}{\multicolumn{2}{|c|}{ Açõcs }} & \multicolumn{3}{|c|}{$1 / 2$} \\
\hline & & $\psi_{0}$ & $\psi_{1}{ }^{1)}$ & $\psi_{2}$ \\
\hline \multirow{3}{*}{$\begin{array}{l}\text { Cargas } \\
\text { acidentais de } \\
\text { edifícios }\end{array}$} & $\begin{array}{l}\text { Locais em que não há predominância de } \\
\text { pesos de equipamentos que permanecem } \\
\text { fixos por longos períodos de tempo, nem de } \\
\text { elevadas concentraçóes de pessoas }\end{array}$ & 0,5 & 0,4 & 0,3 \\
\hline & $\begin{array}{l}\text { Locais em que há predominância de pesos } \\
\text { de equipamentos que permanecem fixos por } \\
\text { longos períndos de tempo oll de elevada } \\
\text { concentração de pessoas }\end{array}$ & 0,1 & $0, b$ & 0,4 \\
\hline & Biblioteca, arquivos, oficinas e garagens & 0.8 & 0,7 & 0,6 \\
\hline Vento & $\begin{array}{l}\text { Pressão dinâmica do vento nas estruturas } \\
\text { em geral }\end{array}$ & 0,6 & 0,3 & 0 \\
\hline Temperatura & $\begin{array}{l}\text { Varıaçöes unitormes de temperatura em } \\
\text { relaçâo à médıa anual local }\end{array}$ & 0,6 & 0,5 & 0,3 \\
\hline
\end{tabular}

\subsection{MOMENTO NEGATIVO NOS APOIOS}

A continuidade presente entre as lajes L1 e L3 é o alvo da análise dos momentos negativos nos apoios. Como foi dito no capítulo 2, Magalhães (2001) mostra que as lajes com elevados graus de redistribuição dos momentos fletores negativos $(\eta)$ apresentam uma boa capacidade de redistribuição de esforços devido à capacidade dos apoios internos de desenvolverem rotações plásticas.

A NBR 6118:2003 limita em 15\% a redistribuição para estruturas de nós móveis. É denominado $\delta$ o coeficiente de redistribuição. É possível adotar outro valor desde que seja feita análise não-linear com verificação da capacidade de 
rotação das rótulas plásticas. Magalhães (2001) recomenda valores maiores que $40 \%$. O exemplo utiliza $60 \%$ de redistribuição.

Os valores calculados dos momentos fletores estão baseados nos dados previamente fornecidos e estão escritos em $\mathrm{kN} \cdot \mathrm{m}$ por nervura. Após a compatibilização dos momentos fletores, resulta que 0 momento fletor característico elástico negativo entre as lajes $L 1$ e $L 3$ é de $M_{k}=-1,65$ $\mathrm{kN}$.m/vigota. Adotando a redistribuição de $60 \%$, resulta num momento fletor negativo de $-1,0 \mathrm{kN} . \mathrm{m} / \mathrm{vigota}$. Os momentos fletores positivos aumentam para 1,70 e $0,85 \mathrm{kN} \cdot \mathrm{m} / \mathrm{vigota}$, respectivamente para a laje L3 e L1. A figura 4.6 mostra os valores dos momentos fletores das lajes antes e depois da redistribuição de momento fletor.

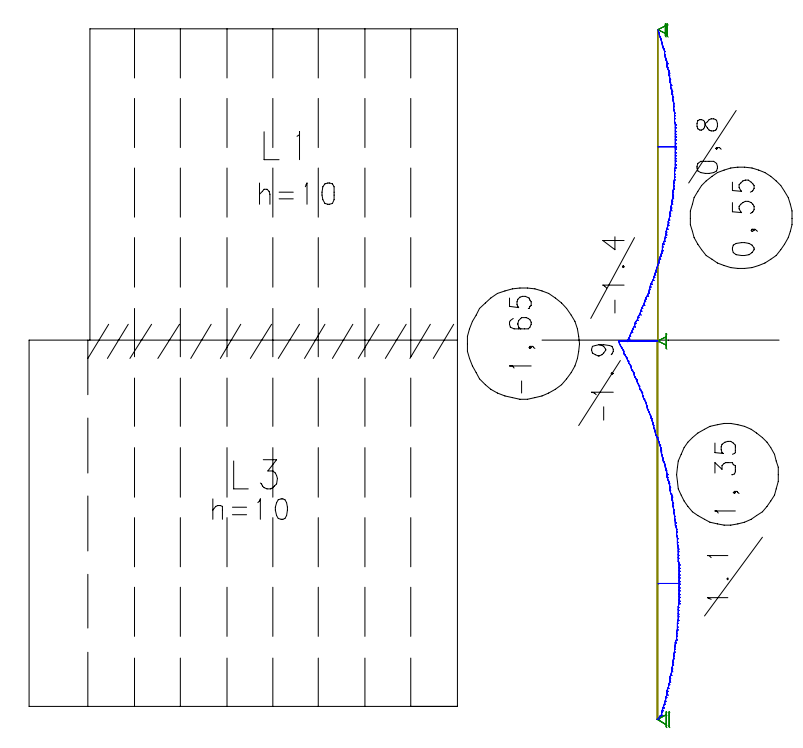

sem

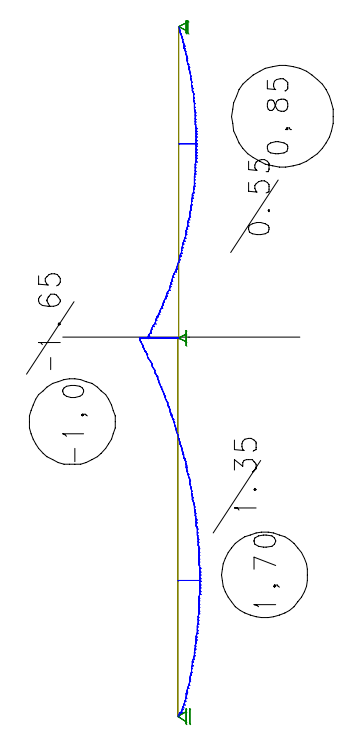

com

Figura 4.6 - Momentos fletores das lajes L1 e L3, com e sem redistribuição

No entanto, deve-se calcular o momento negativo resistente da nervura para comparar com 0 momento solicitante encontrado. Adotando 0 dimensionamento no limite dos domínios 3 e 4, para obter o máximo momento resistente da seção, temos a profundidade da linha neutra limite em 0,628. A laje tem $10 \mathrm{~cm}$ de altura e cobrimento de $1,5 \mathrm{~cm}$, portanto, a altura útil da seção é 
$8 \mathrm{~cm}$. O braço de alavanca $(z)$ entre as forças de tração e compressão é definido como a altura útil menos a metade da altura de $\mathrm{y}_{34}$.

$$
\begin{gathered}
d=h-c-\frac{\phi}{2}=10-1,5-0,5=8 \mathrm{~cm} \\
\frac{x}{d}=0,628 \Rightarrow x=0,628 \cdot 8=5,02 \mathrm{~cm} \\
M_{R d}=b_{w} \cdot y_{34} \cdot 0,85 \cdot f_{c d} \cdot z_{34} \\
M_{R d}=9 \cdot 0,8 \cdot 5,02 \cdot 0,85 \cdot \frac{2,0}{1,4} \cdot\left(8-\frac{0,8.5,02}{2}\right) \cong 263 \mathrm{kN} \cdot \frac{\mathrm{cm}}{\text { vigota }} \\
M_{R d}=-2,63 \mathrm{kN} \cdot \frac{\mathrm{m}}{\text { vigota }} \text { ou } M_{R k}=-1,88 \mathrm{kN} \cdot \frac{\mathrm{m}}{\text { vigota }}
\end{gathered}
$$

Como $M_{s d}=1,40 \leq M_{r d}=2,63$, o dimensionamento está correto. Nota-se que sem a redistribuição, ou com um valor de redistribuição menor que $60 \%$ teríamos que aumentar a seção da laje próxima ao apoio.

\subsection{CÁLCULO MANUAL APROXIMADO}

Para comparar e analisar os valores encontrados pelos Sistemas TQS a serem mostrados no item 4.6 deste capítulo, é realizado aqui uma análise linear através de um cálculo manual das flechas.

Primeiramente, precisa-se calcular o momento de inércia da seção bruta de concreto $\left(\mathrm{I}_{\mathrm{g}}\right)$. Admitindo a largura da mesa colaborante da laje igual ao intereixo, de $42 \mathrm{~cm}$, pode-se encontrar a altura do centro de gravidade da seção transversal da laje L3, em análise, segundo a expressão 4.6.

$$
y_{c g}=\frac{\left(b_{f}-b_{w}\right) \cdot\left(\frac{h_{f}}{2}\right)^{2}+b_{w} \cdot \frac{h^{2}}{2}}{A_{g}}
$$




$$
y_{c g}=\frac{(42-9) \cdot\left(\frac{3}{2}\right)^{2}+9 \cdot \frac{10^{2}}{2}}{33 \cdot 3+9 \cdot 10}=3,16 \mathrm{~cm}
$$

$$
I_{1 g}=\frac{42 \cdot 3^{3}}{12}+\frac{9 \cdot 10^{3}}{12}+33 \cdot 3 \cdot\left(3,16-\frac{3}{2}\right)^{2}+9 \cdot 10 \cdot\left(3,16-\frac{10}{2}\right)^{2}=1352,25 \mathrm{~cm}^{4}
$$

Este valor do momento de inércia será utilizado para o cálculo da flecha inicial da laje L3 para a análise linear. A expressão 4.7 para o cálculo aproximado da flecha máxima, considerando a vinculação da laje como apoiadaapoiada, é de:

$$
a=\frac{5}{384} \cdot \frac{p \cdot l^{4}}{E_{c S} \cdot I_{I}}
$$

Considerando a vinculação da laje como apoiada-engastada, a expressão 4.8 para o cálculo da flecha é:

$$
a=\frac{3}{554} \cdot \frac{p \cdot l^{4}}{E_{c S} \cdot I_{I}}
$$

Para a combinação quase permanente, como descrita na tabela 4.1 deste capítulo, as cargas acidentais são multiplicadas por 0,3. Assim, tem-se que 0 carregamento final na vigota, será de:

$$
\begin{gathered}
p=[\text { peso próprio }+ \text { permanente }+(0,3 \cdot \text { sobrecarga })] \cdot \text { intereixo } \\
p=[1,71+1,00+(0,3 \cdot 2,00)] \cdot 0,42=1,39 \mathrm{kN} / \mathrm{m}
\end{gathered}
$$

Portanto, a flecha máxima inicial para laje apoiada-apoiada, na análise linear pelo cálculo aproximado é de (o valor de $10^{-2}$ no final da expressão é devido à correção de unidades): 


$$
a=\frac{5}{384} \cdot \frac{1,39 \cdot 3,35^{4}}{2380 \cdot 1,35 \cdot 10^{-5}} \cdot 10^{-2}=\mathbf{0}, \mathbf{7 1} \mathbf{c m}
$$

Para a laje apoiada-engastada, a flecha será de:

$$
a=\frac{3}{554} \cdot \frac{1,39 \cdot 3,35^{4}}{2380 \cdot 1,35 \cdot 10^{-5}} \cdot 10^{-2}=\mathbf{0}, \mathbf{3 0} \mathbf{c m}
$$

Como a análise é linear, pode ser feita uma proporção entre o momento fletor obtido para os casos de laje apoiada-apoiada e apoiada-engastada. Esta proporção será aplicada para as flechas. Com a redução do momento negativo devido à redistribuição de 60\%, a flecha estará entre o caso apoiada-apoiada e o caso apoiada-engastada, já que o engastamento da laje não foi realizado por completo. Assim, têm-se a relação dos momentos fletores positivos máximos em cada caso associado à flecha correspondente à vinculação aplicada, conforme a tabela 4.2:

\begin{tabular}{lcc}
\multicolumn{3}{l}{ Tabela 4.2 - Momento fletor positivo e flecha para } \\
\hline CASO & $\begin{array}{c}\text { Momento fletor } \\
\text { (kN.m) }\end{array}$ & $\begin{array}{c}\text { Flecha } \\
\text { (cm) }\end{array}$ \\
\hline Apoio-apoio & 1,89 & 0,71 \\
\hline Apoio-engaste & 1,35 & 0,30 \\
\hline $\begin{array}{l}\text { Intermediário } \\
\text { (redistribuição } \\
\text { em 60\%) }\end{array}$ & 1,70 & $\mathbf{0 , 5 7}$ \\
\hline
\end{tabular}

Não será calculada aqui a flecha para a análise não-linear já que seria necessário considerar para o cálculo uma viga contínua com trechos de momento fletor positivo e negativo. A inércia média de Branson não poderia ser aplicada diretamente, sendo necessário realizar ajustes para que o cálculo se aproxime o máximo possível do real. 


\subsection{ESTADO LIMITE DE DEFORMAÇÕES EXCESSIVAS (ELS-DEF)}

A análise linear obtida pelo TQS através da grelha mostra os valores dos deslocamentos das lajes pré-moldadas formadas por vigotas com armação treliçada. A laje L3, com o maior vão, resultou em um deslocamento linear de $\mathbf{0 , 6 4} \mathbf{~ c m}$ (ver figura 4.7), extraído do visualizador de grelha dos Sistemas TQS. Este valor é da flecha inicial, sem a multiplicação de nenhum coeficiente que leve em conta a fissuração e fluência do concreto. A análise não-linear resultou em uma flecha inicial de $\mathbf{0 , 7 4} \mathbf{c m}$ (figura 4.8).

O limite do deslocamento para o efeito da aceitabilidade sensorial visual com todas as cargas, segundo uma combinação quase permanente com $30 \%$ da carga acidental, é de $\mathrm{L} / 250$ (deslocamentos visíveis). Como o menor vão da laje é de $3,35 \mathrm{~m}$, o limite é de $\mathbf{1 , 3 4} \mathrm{cm}$. Portanto, a laje L3 formada por vigotas treliçadas atende à NBR 6118:2003 para o efeito da sensibilidade sensorial, no ELS-DEF. É necessário verificar também a flecha final da laje e comparar com o valor limite. Isto está feito no item a seguir.

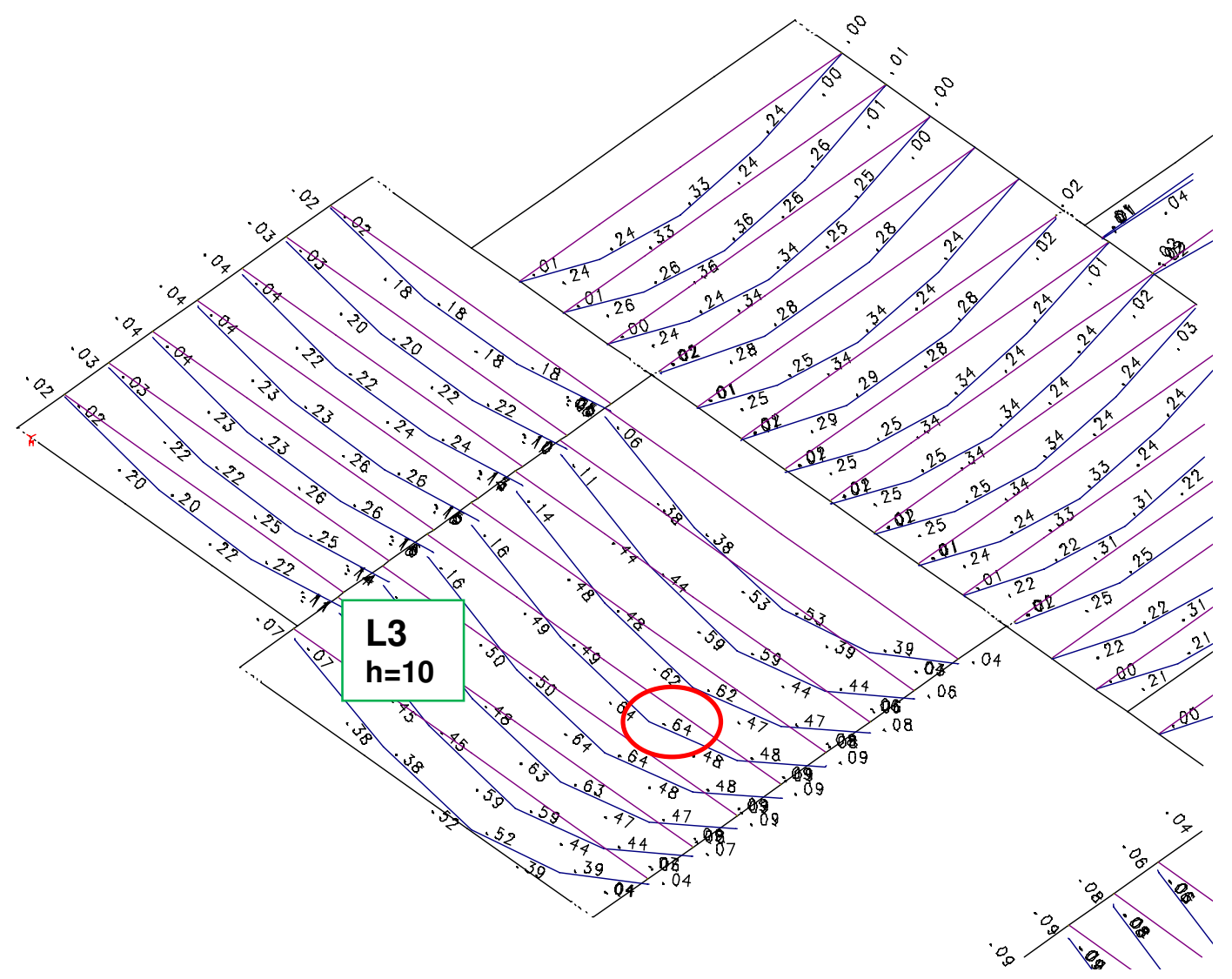

Figura 4.7 - Flechas iniciais da análise linear pelo TQS 


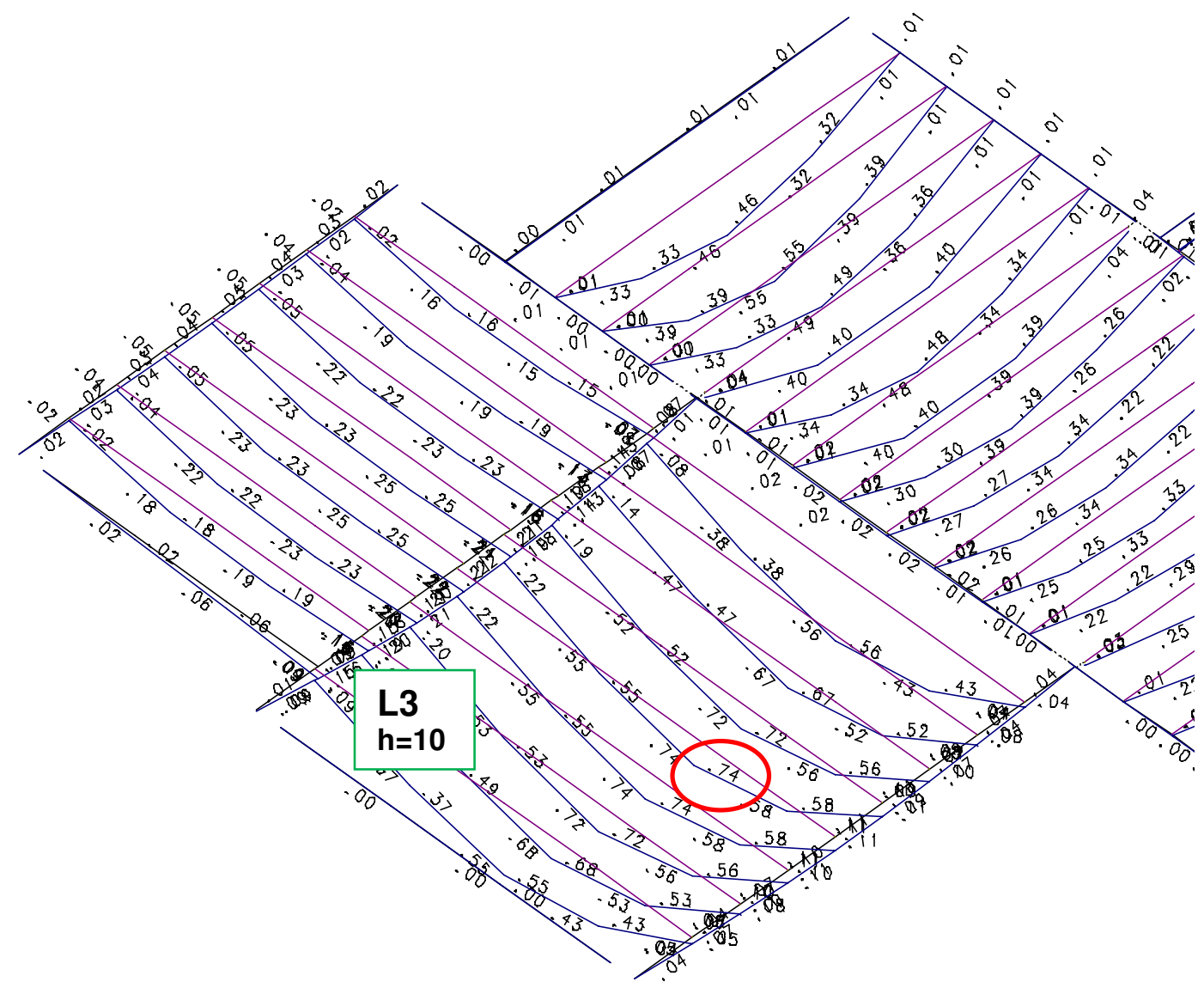

Figura 4.8 - Flechas da análise não-linear pelo TQS

Para as lajes maciças o deslocamento máximo encontrado para a laje L3, de maior vão, foi de $0,17 \mathrm{~cm}$ (ver figura 4.9) para a análise linear através da analogia de grelha, ressaltando que este valor é da flecha inicial, sem considerar a deformação lenta. Para a análise não-linear, o deslocamento obtido foi de 0,20 $\mathrm{cm}$ (ver figura 4.10). Note a diferença de deslocamentos entre as lajes formadas por vigotas treliçadas e as maciças, cerca de quatro vezes menores. E também apresenta valores de flecha menores que o limite especificado pela NBR 6118:2003. 


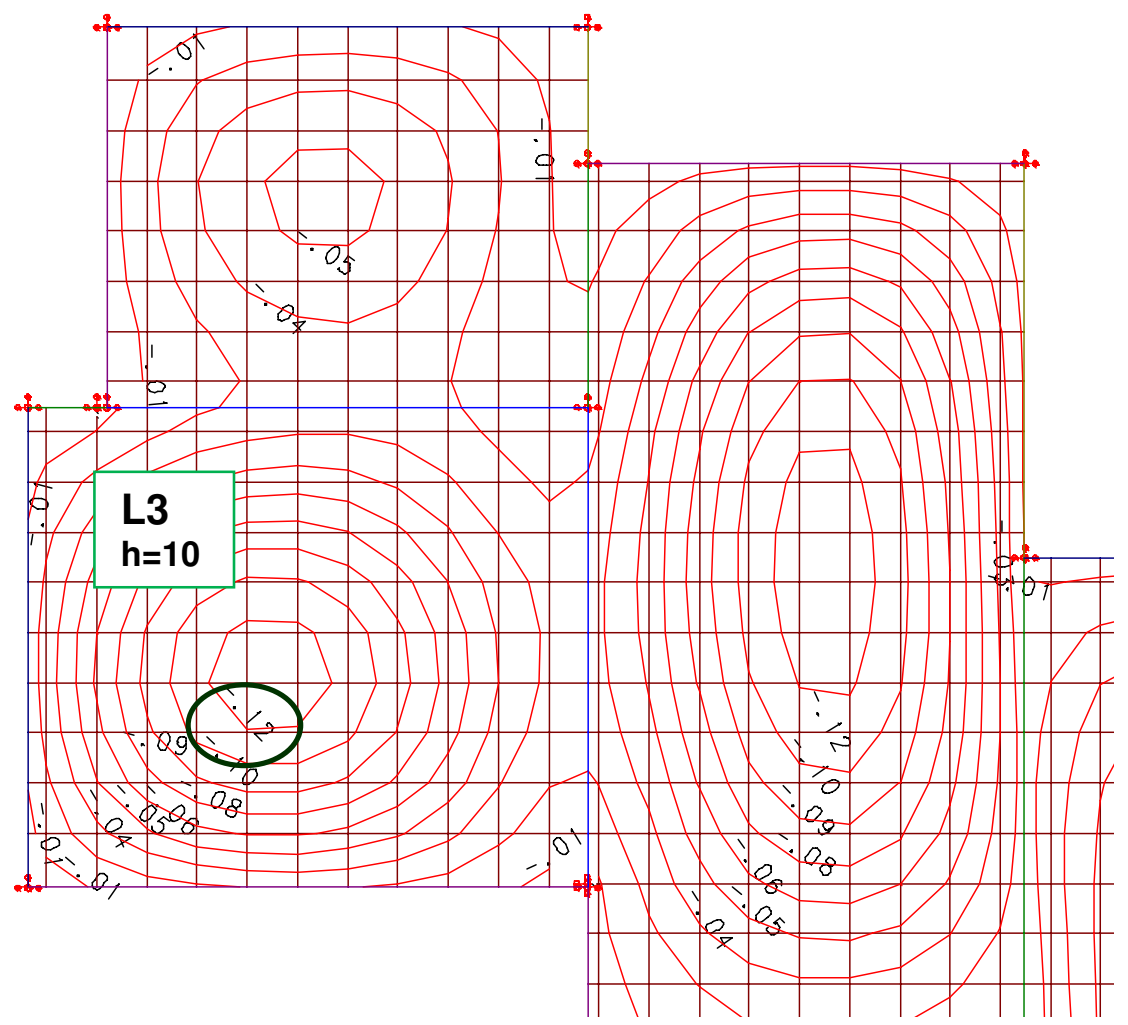

Figura 4.9 - Flechas iniciais da análise linear pelo TQS para lajes maciças

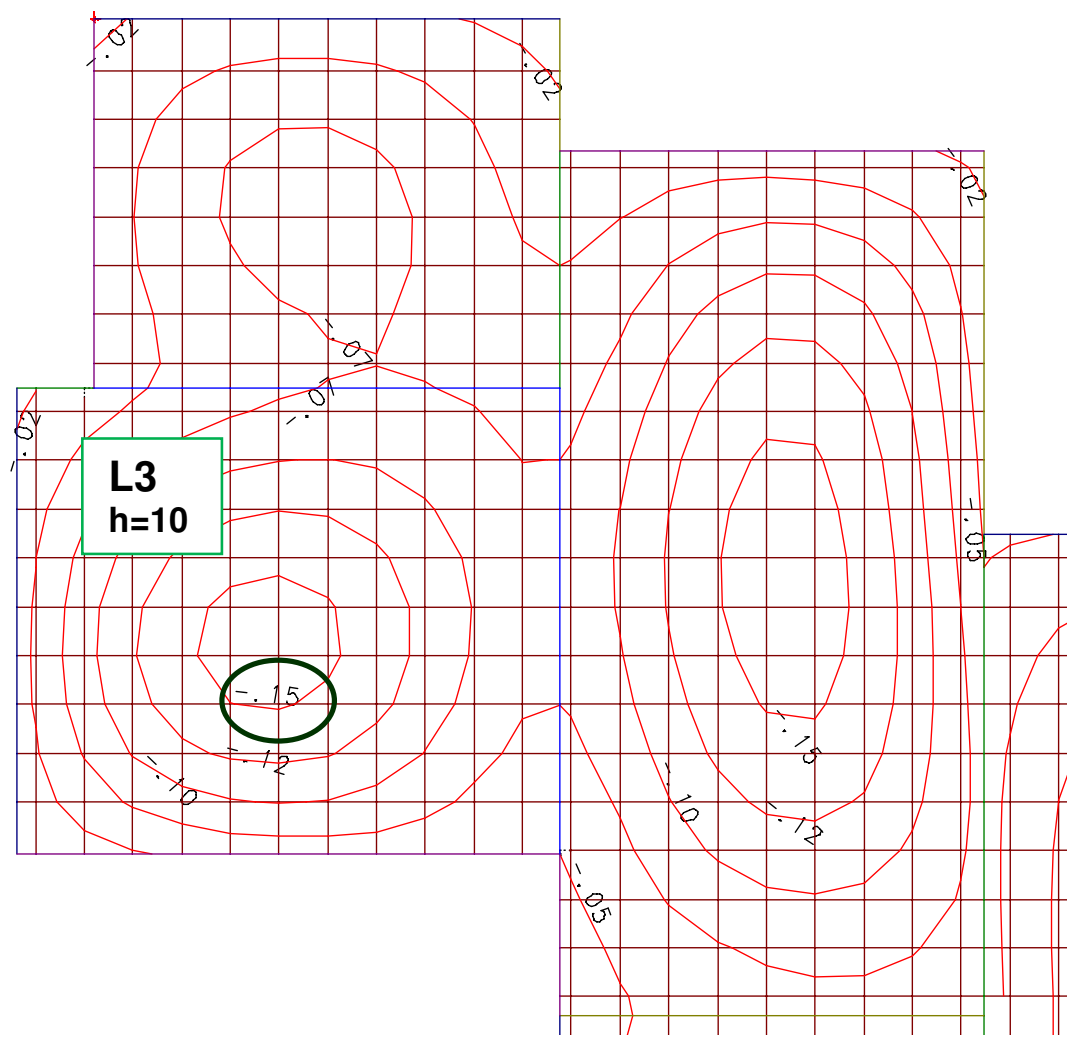

Figura 4.10 - Flechas iniciais da análise não-linear pelo TQS para lajes maciças 
A tabela resumo 4.3 mostra todos os valores obtidos das análises linear e não-linear pelo TQS das lajes treliçadas e maciças, além do valor da flecha através do cálculo manual aproximado e linear da laje L3.

\begin{tabular}{|c|c|c|}
\hline $\begin{array}{l}\text { Laje L3 } \\
\mathrm{h}=10 \mathrm{~cm}\end{array}$ & Análise linear & Análise não-linear \\
\hline $\begin{array}{l}\text { Manual aproximado (c/ } \\
\text { vigotas treliçadas) }\end{array}$ & $0,57 \mathrm{~cm}$ & - \\
\hline $\begin{array}{l}\text { c/ vigotas treliçadas } \\
\text { (TQS) }\end{array}$ & $0,64 \mathrm{~cm}$ & $0,74 \mathrm{~cm}$ \\
\hline Maciça (TQS) & $0,12 \mathrm{~cm}$ & $0,15 \mathrm{~cm}$ \\
\hline
\end{tabular}

A diferença do valor da flecha encontrada pelo cálculo manual aproximado e o feito pelo programa TQS é de $12 \%$. São valores próximos e comprova o que foi obtido pelo programa de cálculo estrutural. A tabela resumo 4.3 mostra todos os valores obtidos pelas análises. Como foi dito no capítulo 2 deste presente trabalho, esperava-se que as flechas da análise não-linear fossem maiores que da análise linear, já que se tem a contribuição da fissuração do concreto. E foi o que ocorreu, comprovando a afirmação. Além disso, observa-se que os valores das flechas para as lajes formadas por vigotas com armação treliçada foram quatro vezes maiores quando comparadas com as lajes maciças de mesma espessura.

\subsection{FLECHAS DIFERIDAS AO LONGO DO TEMPO SEGUNDO MERLIN (2006)}

Como foi dito no capítulo 2 deste trabalho, Merlin (2006) desenvolveu expressões para determinar o coeficiente multiplicador da flecha imediata para lajes pré-moldadas formadas por vigotas com armação treliçada, através de uma análise probabilística e determinística. 
Para os cálculos a seguir foi utilizada a referência da cidade de São Paulo, capital do estado de São Paulo. Foi utilizado $19^{\circ} \mathrm{C}$ como temperatura média anual e 78\% para a média anual da umidade relativa.

Analisando apenas a laje L3 do exemplo de aplicação, extraímos os dados presentes na tabela 4.4 para o cálculo dos coeficientes propostos por Merlin (2006). Todas as expressões foram feitas baseadas em lajes prémoldadas biapoiadas. Para lajes com continuidade, Merlin (2006) ressalta que podem ser utilizadas as expressões. Alerta para que haja fissuração no vão compatível com a laje biapoiada correspondente, além da fissuração no apoio.

Tabela 4.4 - Dados do exemplo de aplicação

\begin{tabular}{ccccccc}
\hline $\begin{array}{c}\mathrm{q} \\
\left(\mathrm{kN} / \mathrm{m}^{2}\right)\end{array}$ & $\begin{array}{c}\text { As } \\
\left(\mathrm{cm}^{2}\right)\end{array}$ & $\begin{array}{c}\mathrm{h} \\
(\mathrm{m})\end{array}$ & $\begin{array}{c}\mathrm{p} \\
(\mathrm{kN} / \mathrm{m})\end{array}$ & $\begin{array}{c}\mathrm{I} \\
(\mathrm{m})\end{array}$ & $\begin{array}{c}\mathrm{U} \\
(\%)\end{array}$ & $\begin{array}{c}\mathrm{T} \\
\left({ }^{\circ} \mathrm{C}\right)\end{array}$ \\
\hline 4,7 & 2,28 & 0,10 & 1,97 & 3,35 & 78 & 19 \\
\hline
\end{tabular}

Utilizando as expressões 2.2 a 2.4 descritas no capítulo 2 deste trabalho, além das expressões 2.5 e 2.6 para determinar o coeficiente $\alpha_{U, T}$, montam-se as tabelas 4.5 e 4.6 com os cálculos das análises determinísticas e probabilísticas.

$$
\alpha=\alpha_{\text {básico }} \cdot \alpha_{U, T} \quad \text { e } \quad \alpha_{\text {básico }}=3,73 \cdot k+0,18
$$

com:

$$
\kappa=\frac{A_{s} \cdot h^{2,05}}{p^{1,5} \cdot l^{3}} \cdot 10^{3}
$$

Tabela 4.5 - Análise determinística (MERLIN, 2006)

\begin{tabular}{ccccc}
\hline $\mathrm{q}$ & $\mathrm{k}$ & $\alpha_{\text {básico }}$ & $\alpha_{\mathrm{U}, \mathrm{T}}$ & $\alpha$ \\
\hline $\left.\mathrm{kN} / \mathrm{m}^{2}\right)$ & 0,195 & 0,91 & 0,71 & 0,64 \\
\hline
\end{tabular}


Tabela 4.6 - Análise probabilística (MERLIN, 2006)

\begin{tabular}{ccccc}
\hline $\begin{array}{c}q \\
\left(\mathrm{kN} / \mathrm{m}^{2}\right)\end{array}$ & $\mathrm{k}$ & $\alpha_{\text {básico }}$ & $\alpha_{\mathrm{U}, \mathrm{T}}$ & $\alpha$ \\
\hline 4,7 & 0,195 & 0,91 & 1,21 & 1,10 \\
\hline
\end{tabular}

Sabendo que a flecha diferida é avaliada através do coeficiente multiplicador $\alpha$ da flecha instantânea, tem-se a seguinte expressão:

$$
\alpha=\frac{a_{\text {total }}-a_{\text {inst }}}{a_{\text {inst }}}
$$

Reescrevendo a expressão acima, tem-se que:

$$
a_{\text {total }}=(\alpha+1) \cdot a_{\text {inst }}
$$

O deslocamento para a laje L3 segundo a análise linear calculada pelo software TQS, foi de $\underline{0,64 \mathrm{~cm}}$. Este valor corresponde à flecha inicial ou instantânea. Já com o coeficiente multiplicador encontrado através das formulações de Merlin (2006), o deslocamento final é de:

$$
a_{\text {total }}=(1,1+1) \cdot 0,64=\mathbf{1}, \mathbf{3 4} \mathbf{c m}
$$

Já para a análise não-linear, o valor da flecha inicial da laje L3 calculada pelo TQS, foi de $\underline{0,74 \mathrm{~cm}}$. O valor final da flecha, utilizando o coeficiente obtido pelas expressões de Merlin (2006) é de 1,55 cm.

A tabela 4.7 resume todos os valores após a multiplicação do coeficiente proposto por Merlin (2006), inclusive os valores das flechas ao longo do tempo para as lajes maciças de $10 \mathrm{~cm}$ de espessura. 
Tabela 4.7 - Tabela resumo das flechas diferidas ao longo do tempo

\begin{tabular}{ccc}
\hline $\begin{array}{c}\text { Laje L3 } \\
\mathrm{h}=10 \mathrm{~cm}\end{array}$ & $\begin{array}{c}\text { Análise } \\
\text { linear }\end{array}$ & $\begin{array}{c}\text { Análise não- } \\
\text { linear }\end{array}$ \\
\hline \hline $\begin{array}{c}\text { MERLIN } \\
(2006)\end{array}$ & $1,34 \mathrm{~cm}$ & $1,55 \mathrm{~cm}$ \\
\hline
\end{tabular}

Nota-se que o valor encontrado do coeficiente multiplicador para as flechas diferidas ao longo do tempo, de acordo com Merlin (2006) é maior que os coeficientes da NBR 6118:2003. Já era esperado um valor maior calculado pelas expressões de Merlin (2006), pois, como foram mostrados no capítulo 2 deste presente trabalho, geralmente os coeficientes apresentam valores maiores.

Segundo a NBR 6118:2003, o limite segundo a limitação visual da aceitabilidade sensorial é de $1,34 \mathrm{~cm}$. Assim, a laje formada por vigotas com armação treliçada L3 do exemplo de aplicação não atende à limitação de I/250 da NBR 6118:2003. Dessa forma, uma solução seria aumentar a altura da laje ou realizar uma contraflecha, de no máximo l/350.

Os resultados confirmam o que foi dito no capítulo 2 deste trabalho de que os coeficientes fornecidos pela NBR 6118:2003 para o cálculo das flechas diferidas ao longo do tempo subestimam os valores reais.

\subsection{ANÁLISE DO ESTADO LIMTE DE VIBRAÇÕES EXCESSIVAS}

Um grande problema das estruturas de concreto pré-moldado nos dias de hoje diz respeito à vibração. Sua análise se torna muito importante já que as estruturas estão se tornando cada vez mais esbeltas e menos rígidas. Como exposto no item 2.4.2 deste trabalho sobre Estado Limite de Vibrações Excessivas, a freqüência natural da estrutura deve ser comparada com a freqüência mínima necessária, estabelecida por norma. Quando $f_{n} \geq f_{\text {mín }}$ a estrutura não apresenta o risco de entrar em ressonância ou de apresentar 
vibrações excessivas. Por outro lado, quando $f_{n}<f_{\text {mín }}$ é necessário alterar as características estruturais de rigidez.

Não é comum a utilização de vigotas treliçadas pré-moldadas em lajes que venham a ter atividades ritmadas como eventos esportivos ou concertos musicais. Portanto serão apresentados aqui apenas os cálculos para a vibração causada pela caminhada.

Pela NBR 6118:2003 é necessário que $t_{n} \geq 1,2 f_{\text {min }}$.

Com base nos efeitos da ressonância, a frequência natural mínima para o piso é dada pela expressão 2.11 do capítulo 2 deste presente trabalho, segundo Mast (2001).

$$
f_{\min }=2,86 \cdot \ln \left(\frac{F}{\zeta \cdot W_{e}}\right)
$$

Para o exemplo em questão, e consultando a tabela 2.2 do capítulo 2 deste presente trabalho, encontra-se 0 valor para a constante $F$ de $58 \mathrm{kN}$, correspondente à residência. $O$ valor de $\zeta$ é 0,02 para pisos com pouca mobília. Os dois fatores acima mencionados são os mais desfavoráveis para este tipo de análise. Foi adotado sobrecarga de $0,25 \mathrm{kN} / \mathrm{m}^{2}$ porque deseja-se adotar valores de cargas variáveis mais realistas, seguindo recomendação de Mast (2001).

As cargas atuantes são:

$$
\begin{aligned}
& \text { - peso próprio }=1,71 \mathrm{kN} / \mathrm{m}^{2} \\
& \text { - revestimento }=1,00 \mathrm{kN} / \mathrm{m}^{2} \\
& \text { - sobrecarga }=0,25 \mathrm{kN} / \mathrm{m}^{2} \\
& \text { Total } \quad=2,96 \mathrm{kN} / \mathrm{m}^{2}
\end{aligned}
$$

A largura $B$ do painel adotada será de $0,6 L$, já que a laje apresenta espessura pequena e pequena rigidez à torção.

Para a freqüência natural da estrutura é necessário calcular o módulo de elasticidade dinâmico e o momento de inércia da seção da laje.

$$
f_{n}=R \sqrt{\frac{E \cdot I \cdot g}{w \cdot L^{4}}}
$$




$$
\begin{gathered}
E_{c s, d i n}=1,2 \cdot E_{c s} \\
E_{c s}=0,85 \cdot E_{c i} \\
E_{c i}=5600 \cdot f_{c k}^{1 / 2}
\end{gathered}
$$

Resumindo, tem-se que:

$$
E_{c s, d i n}=1,2 \cdot 0,85 \cdot 5600 \cdot f_{c k}^{1 / 2}
$$

Utilizando concreto com resistência característica à compressão de 25 MPa, o módulo de elasticidade dinâmico é de 28560 MPa.

O momento de inércia da seção bruta de concreto é de $1352,25 \mathrm{~cm}^{4}$.

As lajes do pavimento em análise apresentam continuidade. Dessa forma, a vinculação da laje é do tipo apoio-engaste e resulta na constante " $R$ " de 2,45. A carga linear $w$ é obtida pelo produto do intereixo da laje pelo valor da carga total por metro quadrado.

Todos estes dados estão reunidos na tabela 4.8 para vãos de laje entre 0 e 7 metros. A figura 4.11 mostra as curvas obtidas pelos dados fornecidos pela tabela 4.8, tanto para a freqüência mínima e a freqüência natural nas lajes formadas por vigotas com armação treliçada de $10 \mathrm{~cm}$ de espessura.

Tabela 4.8 - Freqüência mínima e natural para LT10 (7+3)

\begin{tabular}{cccccc}
\hline $\begin{array}{c}\mathrm{L} \\
(\mathrm{m})\end{array}$ & $\begin{array}{c}\mathrm{B} \\
(\mathrm{m})\end{array}$ & $\begin{array}{c}W e \\
(\mathrm{kN})\end{array}$ & $\begin{array}{c}\mathrm{f}_{\text {min }} \\
(\mathrm{Hz})\end{array}$ & $\begin{array}{c}\mathrm{f}_{\text {nat }} \\
(\mathrm{Hz})\end{array}$ & $\mathrm{f} / \mathrm{f}_{\min }$ \\
\hline \hline 1 & 0,6 & 1,8 & 21,2 & 149,9 & 7,1 \\
\hline 2 & 1,2 & 7,1 & 17,2 & 37,5 & 2,2 \\
\hline 3 & 1,8 & 16,0 & 14,9 & 16,7 & 1,1 \\
\hline 4 & 2,4 & 28,4 & 13,2 & 9,4 & 0,7 \\
\hline 5 & 3 & 44,4 & 12,0 & 6,0 & 0,5 \\
\hline 6 & 3,6 & 63,9 & 10,9 & 4,2 & 0,4 \\
\hline 7 & 4,2 & 87,0 & 10,0 & 3,1 & 0,3 \\
\hline 8 & 4,8 & 113,7 & 9,3 & 2,3 & 0,3 \\
\hline 9 & 5,4 & 143,9 & 8,6 & 1,9 & 0,2 \\
\hline
\end{tabular}




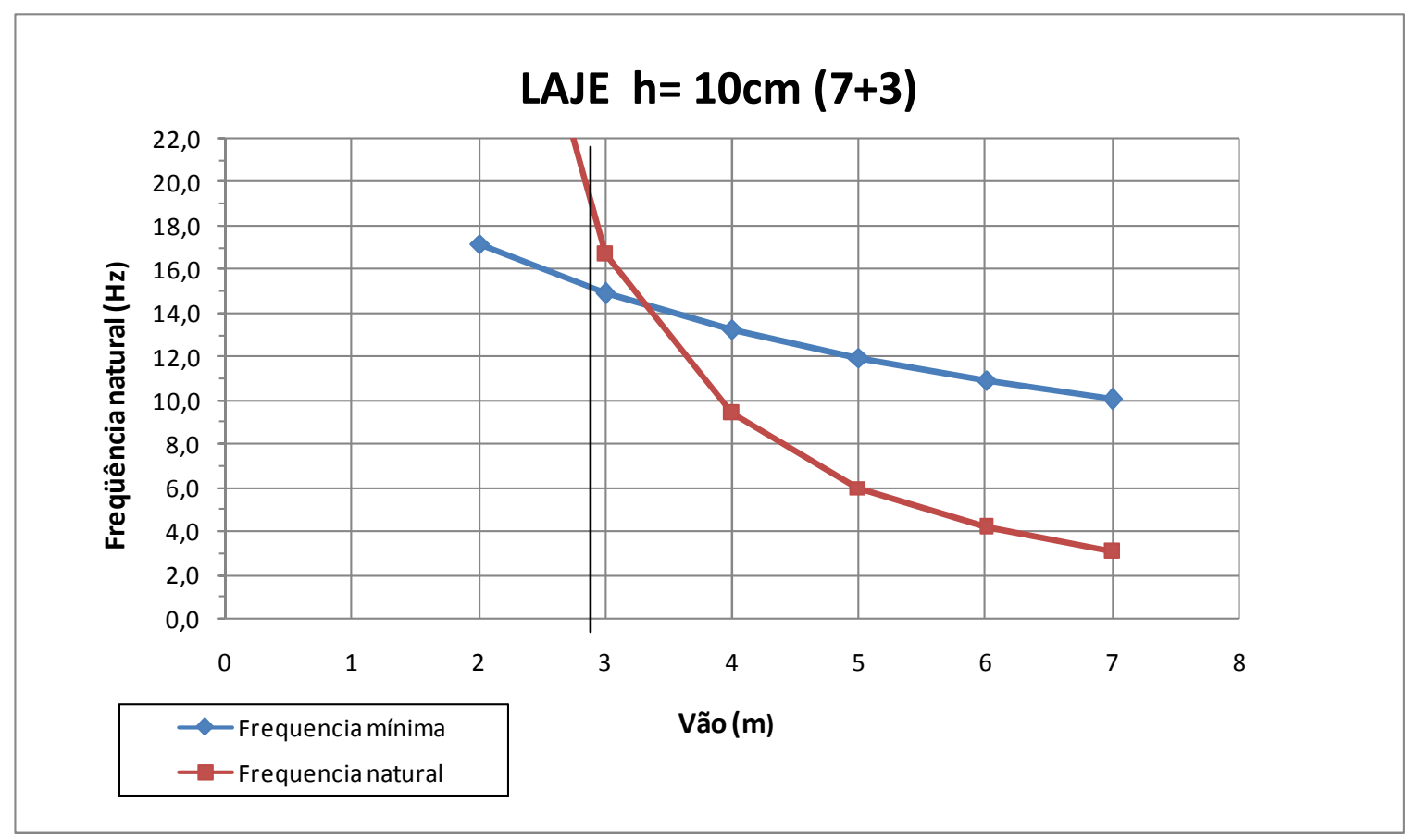

Figura 4.11 - Gráfico das freqüências ao longo dos vãos para LT10 (7+3)

Para garantir que a freqüência mínima do piso seja 1,2 vez maior que a freqüência natural da estrutura (NBR 6118:2003) o máximo vão permitido para a laje é de $\underline{2,9 \mathrm{~m}}$. Para o caso da laje ter vinculação apoio-apoio o máximo vão é de 2,2 $\mathrm{m}$. Apenas a laje L7 do pavimento analisado estaria de acordo com a NBR 6118:2003. A solução seria aumentar a espessura das lajes para $12 \mathrm{~cm}$.

Algumas alternativas serão desenvolvidas aqui frente ao que foi exposto anteriormente, complementando o exemplo. Para a verificação das vibrações excessivas (ELS-VE) será feito para o caso de lajes maciças de $10 \mathrm{~cm}$ e para uma laje formada por vigotas treliçadas de $12 \mathrm{~cm}$ no total. A análise para as lajes maciças é para mostrar o comportamento desta laje, que é uma opção muito utilizada nos edifícios, e compará-las às lajes formadas por vigotas com armação treliçada.

Os valores de $\mathrm{F}$ e $\zeta$ são os mesmos que foram utilizados anteriormente, $58 \mathrm{kN} \mathrm{e} \mathrm{0,02,} \mathrm{respectivamente.} \mathrm{As} \mathrm{cargas} \mathrm{atuantes} \mathrm{são:}$

- peso próprio $=2,50 \mathrm{kN} / \mathrm{m}^{2}$

- revestimento $=1,00 \mathrm{kN} / \mathrm{m}^{2}$

- sobrecarga $=0,25 \mathrm{kN} / \mathrm{m}^{2}$ (análise de ELS)

\section{Total $=3,75 \mathrm{kN} / \mathrm{m}^{2}$}


A largura B do painel adotada será de $L$, já que a laje apresenta significativa rigidez à torção e segue recomendação de Mast (2001).

O momento de inércia da seção bruta de concreto é de $8333,3 \mathrm{~cm}^{4}$ para uma faixa de um metro de laje. A figura 4.12 mostra as curvas obtidas pelos dados fornecidos pela tabela 4.9, tanto para a freqüência mínima e a freqüência natural da laje maciça com $10 \mathrm{~cm}$ de espessura.

Tabela 4.9 - Frequência mínima e natural para laje maciça $h=10 \mathrm{~cm}$

\begin{tabular}{cccccc}
\hline $\begin{array}{c}\mathrm{L} \\
(\mathrm{m})\end{array}$ & $\begin{array}{c}\mathrm{B} \\
(\mathrm{m})\end{array}$ & $\begin{array}{c}W e \\
(\mathrm{kN})\end{array}$ & $\begin{array}{c}\mathrm{f}_{\min } \\
(\mathrm{Hz})\end{array}$ & $\begin{array}{c}\mathrm{f}_{\text {nat }} \\
(\mathrm{Hz})\end{array}$ & $\mathrm{f} / \mathrm{f}_{\min }$ \\
\hline \hline 1 & 1 & 3,8 & 19,0 & 193,3 & 10,2 \\
\hline 2 & 2 & 15,0 & 15,1 & 48,3 & 3,2 \\
\hline 3 & 3 & 33,8 & 12,7 & 21,5 & 1,7 \\
\hline 4 & 4 & 60,0 & 11,1 & 12,1 & 1,1 \\
\hline 5 & 5 & 93,8 & 9,8 & 7,7 & 0,8 \\
\hline 6 & 6 & 135,0 & 8,8 & 5,4 & 0,6 \\
\hline 7 & 7 & 183,8 & 7,9 & 3,9 & 0,5 \\
\hline 8 & 8 & 240,0 & 7,1 & 3,0 & 0,4 \\
\hline 9 & 9 & 303,8 & 6,5 & 2,4 & 0,4 \\
\hline
\end{tabular}

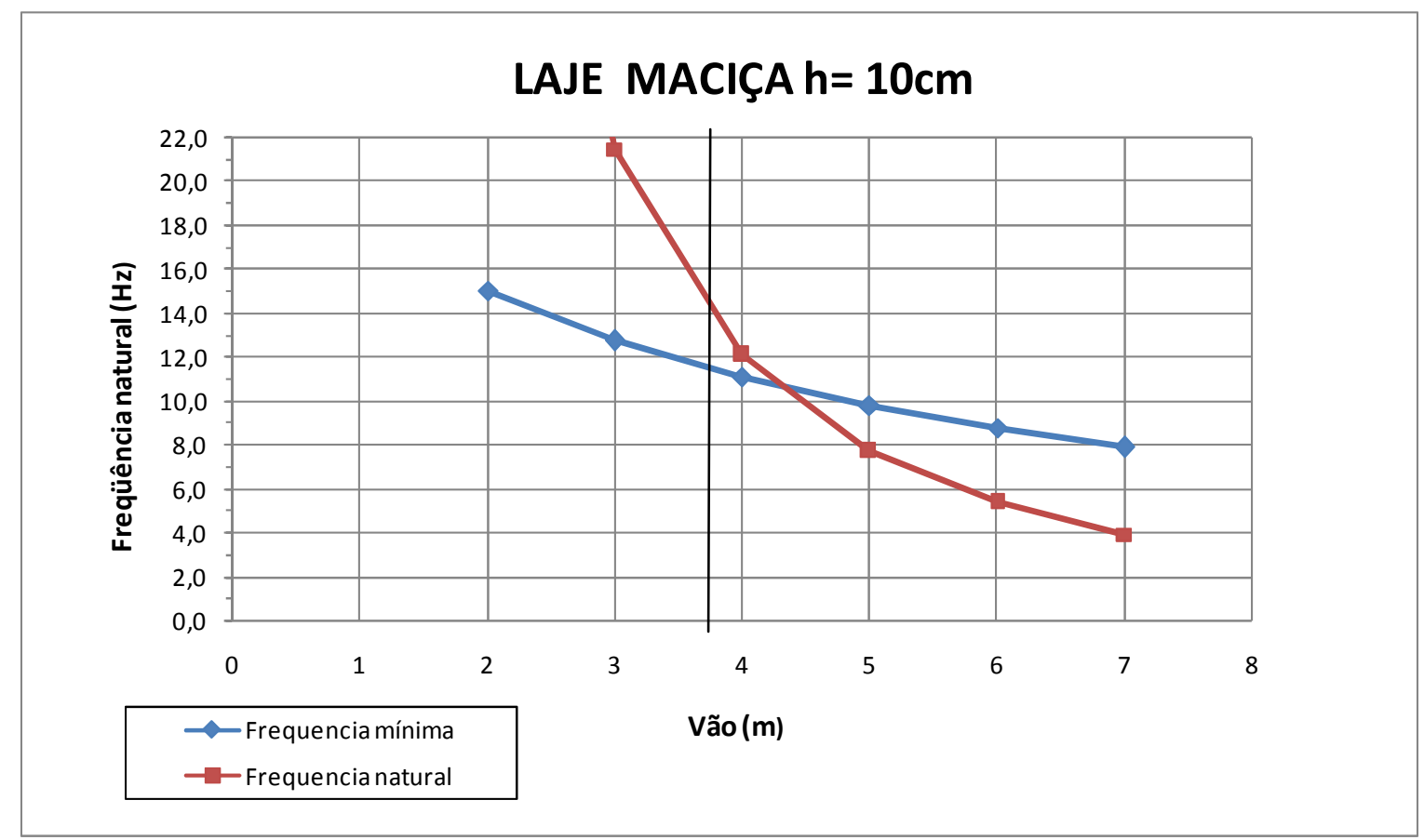

Figura 4.12 - Gráfico das freqüências ao longo dos vãos para laje maciça 
O vão máximo para este caso é de $\underline{3,7 \mathrm{~m}}$, segundo a NBR 6118:2003.

Para efeito de comparação, analisando uma laje formada por vigotas treliçadas com espessura total de $12 \mathrm{~cm}$, sendo $8 \mathrm{~cm}$ da vigota e $4 \mathrm{~cm}$ de capa de concreto, tem-se os seguintes dados:

$$
\begin{aligned}
& -B=0,6 \cdot \mathrm{L} ; \\
& -I_{C}=29142,8 \mathrm{~cm}^{4} \\
& -W_{p}=3,06 \mathrm{kN} / \mathrm{m}^{2}
\end{aligned}
$$

Todos estes dados estão reunidos na tabela 4.9 para vãos de laje entre 0 e 7 metros. A figura 4.13 mostra as curvas obtidas pelos dados fornecidos pela tabela 4.10, tanto para a freqüência mínima e a freqüência natural nas lajes formadas por vigotas com armação treliçada de $12 \mathrm{~cm}$ de espessura.

Tabela 4.10 - Frequência mínima e natural para laje LT12 (8+4)

\begin{tabular}{cccccc}
\hline $\begin{array}{c}\mathrm{L} \\
(\mathrm{m})\end{array}$ & $\begin{array}{c}\mathrm{B} \\
(\mathrm{m})\end{array}$ & $\begin{array}{c}W e \\
(\mathrm{kN})\end{array}$ & $\begin{array}{c}\mathrm{f}_{\min } \\
(\mathrm{Hz})\end{array}$ & $\begin{array}{c}\mathrm{f}_{\text {nat }} \\
(\mathrm{Hz})\end{array}$ & $\mathrm{f} / \mathrm{f}_{\min }$ \\
\hline \hline 1 & 0,6 & 1,8 & 21,1 & 195,3 & 9,3 \\
\hline 2 & 1,2 & 7,3 & 17,1 & 48,8 & 2,9 \\
\hline 3 & 1,8 & 16,5 & 14,8 & 21,7 & 1,5 \\
\hline 4 & 2,4 & 29,4 & 13,1 & 12,2 & 0,9 \\
\hline 5 & 3 & 45,9 & 11,9 & 7,8 & 0,7 \\
\hline 6 & 3,6 & 66,1 & 10,8 & 5,4 & 0,5 \\
\hline 7 & 4,2 & 90,0 & 9,9 & 4,0 & 0,4 \\
\hline 8 & 4,8 & 117,5 & 9,2 & 3,1 & 0,3 \\
\hline 9 & 5,4 & 148,7 & 8,5 & 2,4 & 0,3 \\
\hline
\end{tabular}




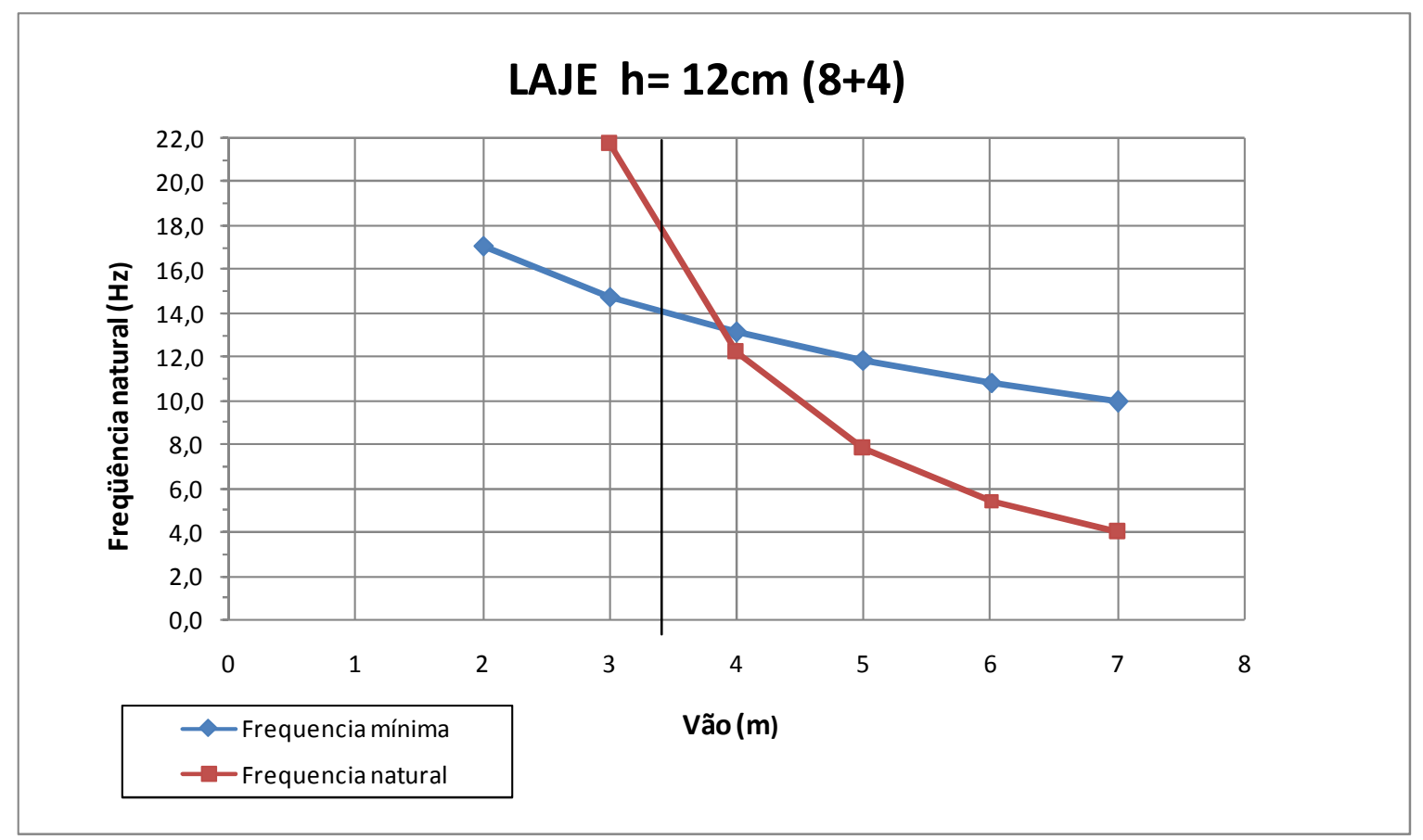

Figura 4.13 - Gráfico das freqüências ao longo dos vãos da LT12 (8+4)

Para este caso de laje formada por vigotas treliçadas com $12 \mathrm{~cm}$ de espessura no total, o vão máximo permitido é de $3,35 \mathrm{~m}$. Portanto, está de acordo com os limites preconizados na NBR 6118:2003 quanto ao ELS-VE. A tabela 4.11 a seguir apresenta o resumo das análises feita para as lajes treliçadas de $10 \mathrm{~cm}$ e $12 \mathrm{~cm}$ de altura e para a laje maciça de $10 \mathrm{~cm}$.

Tabela 4.11 - Tabela resumo da análise de vibração excessiva

\begin{tabular}{ccc}
\hline Tipo de laje & $\begin{array}{c}\text { Máximo vão } \\
\text { permitido }\end{array}$ & $\begin{array}{c}\text { Verificação NBR } \\
6118: 2003\end{array}$ \\
\hline \hline LT10 $(7+3)$ & $2,90 \mathrm{~m}$ & Não OK \\
\hline LT12 (8+4) & $3,35 \mathrm{~m}$ & OK \\
\hline $\begin{array}{c}\text { Maciça } \\
\mathrm{h}=10 \mathrm{~cm}\end{array}$ & $3,70 \mathrm{~m}$ & OK \\
\hline
\end{tabular}


Por fim, deve-se adotar laje com espessura de $12 \mathrm{~cm}$ para evitar vibração excessiva no piso. Mesmo assim, o limite está muito próximo. Foi mostrado que lajes maciças de $10 \mathrm{~cm}$ para o pavimento estariam de acordo com a norma. Há uma contribuição do piso e/ou revestimento aplicado sobre a laje que não foi computado nesta análise. Fica claro que atender à NBR 6118:2003 quanto ao ELS-VE é difícil e torna-se um limitante na escolha da altura da laje.

\subsection{CÁLCULO DE ARMADURA CONTRA O COLAPSO PROGRESSIVO}

Por comodidade, apenas em um trecho do pavimento será estudado para o cálculo da armadura para combater um eventual colapso progressivo. A figura 4.14 mostra exatamente este local. O edifício em questão é composto de quatro pavimentos-tipo mais o térreo, a soma das cargas atuantes sobre as lajes é de $4,7 \mathrm{kN} / \mathrm{m}^{2}$ e o vão entre pilares é de 3,90 metros. Dessa forma, como $\left(g_{k}+q_{k}\right)<$ $7,5 \mathrm{kN} / \mathrm{m}^{2}$ e $\mathrm{I}_{\mathrm{r}}<5,0 \mathrm{~m}$ não é necessário utilizar a majoração $F_{t}^{\prime}$ da equação 2.15 descrita no capítulo 2 deste presente trabalho.

$$
F_{t}=(20+4.5)=40 \mathrm{kN} / \mathrm{m}
$$

A viga com vão teórico de 3,90 m suporta os vãos adjacentes de 3,35 m e 2,65 m. Assim, torna-se necessário fazer uma média destes vãos e multiplicar pela força no tirante $F_{t}$.

$$
F_{t}{ }^{\prime}=40 \cdot \frac{(3,35+2,65)}{2}=120 \mathrm{kN}
$$

Assim, com o aço CA-50 de resistência característica de $500 \mathrm{MPa}$ e utilizando o coeficiente de minoração da resistência do aço de 1,15 , tem-se o valor da área de armadura do tirante.

$$
A_{s}=\frac{120,0}{\frac{50,0}{1,15}}=2,76 \mathrm{~cm}^{2}
$$


São 2,76 cm² de aço distribuídos em $335 \mathrm{~cm}$ entre as lajes L1 e L3. Dessa forma, uma opção são $4 \Phi 10 \mathrm{~mm}\left(3,14 \mathrm{~cm}^{2}\right)$ ou $6 \Phi 8,0 \mathrm{~mm}\left(3,02 \mathrm{~cm}^{2}\right)$. Adotamse 6 barras de $8 \mathrm{~mm}$ com área de armadura efetiva de $3,02 \mathrm{~cm}^{2}$. A posição da armadura em planta é mostrada na figura 4.14.

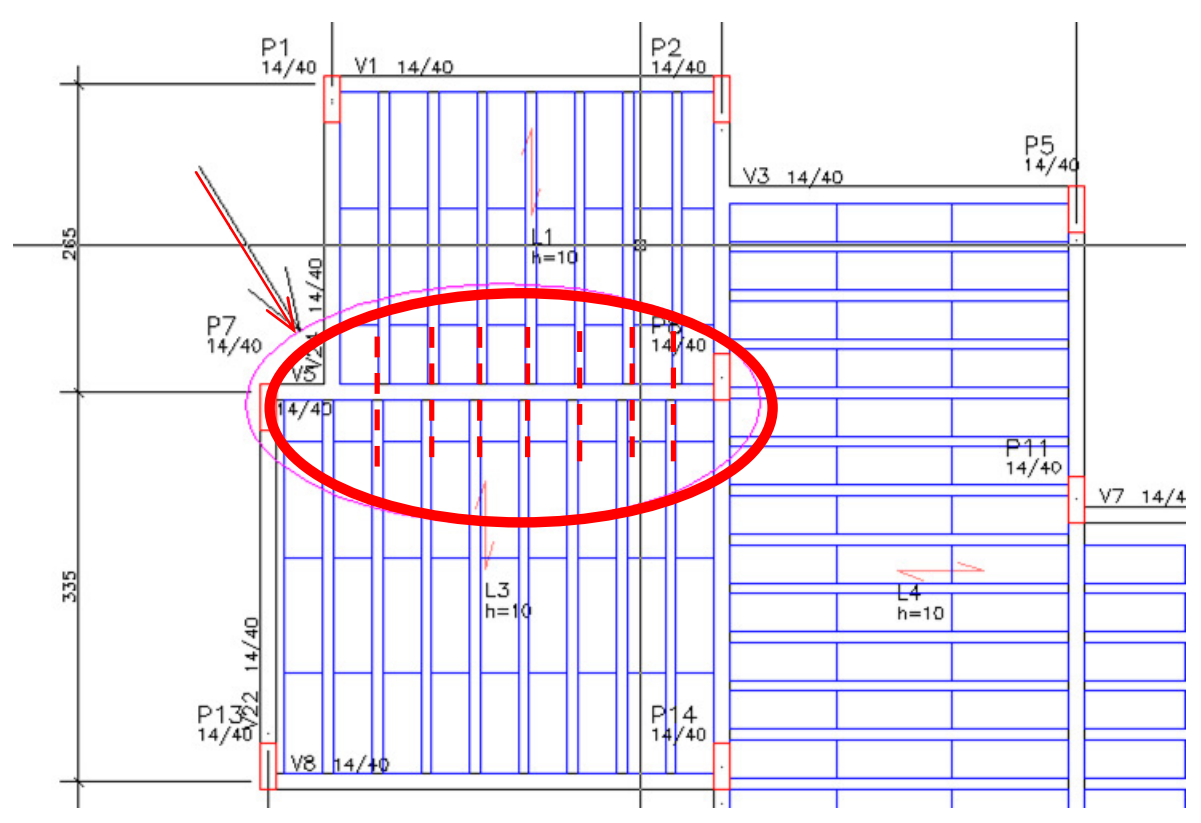

Figura 4.14 - Trecho do pavimento para cálculo do tirante (linhas tracejadas em vermelho)

O comprimento de ancoragem é muito importante e deve ser calculado através da NBR 6118: 2003. Sabendo que o concreto é o C25 ( $\left.f_{c k}=25 \mathrm{MPa}\right)$ e as barras de armadura são nervuradas, em região de má aderência, tem-se que a resistência de aderência de cálculo é dada pela equação 4.15 e indicada na NBR 6118: 2003.

$$
f_{b d}=\eta_{1} \cdot \eta_{2} \cdot \eta_{3} \cdot f_{c t d}
$$

sendo $\eta_{1}, \eta_{2}, \eta_{3}$ : coeficientes para o cálculo da resistência de aderência da armadura passiva; $f_{c t d}$ : resistência de cálculo do concreto à tração direta. 


$$
f_{b d}=2,25 \cdot 0,7 \cdot 1,0 \cdot \frac{0,7 \cdot 0,3 \cdot 25^{2 / 3}}{1,4}=2,02 \mathrm{MPa}
$$

O comprimento de ancoragem básico $I_{b}$ é dado por:

$$
\begin{gathered}
l_{b}=\frac{\phi \cdot f_{y d}}{4 \cdot f_{b d}} \\
l_{b}=\frac{0,8 \cdot 43,5}{4 \cdot 0,202}=43,1 \mathrm{~cm}
\end{gathered}
$$

Porém, como a área de armadura calculada é menor que a área de armadura efetiva, pode-se reduzir este comprimento. Além disso, a presença de gancho nos extremos da barra também permite uma redução.

$$
l_{b, \text { nec }}=\alpha_{1} \cdot l_{b} \cdot \frac{A_{s, \text { calc }}}{A_{s, \text { ef }}} \geq l_{b, \min }
$$

O valor de $\alpha_{1}$ é dado 1,0 para barras sem gancho e 0,7 para barras com gancho e cobrimento no seu plano normal de $c \geq 3 \mathrm{~mm}$. Assim, o comprimento de ancoragem pode ser reduzido para:

$$
l_{b, n e c}=1,0 \cdot 43,1 \cdot \frac{2,80}{3,02}=40 \mathrm{~cm} \geq l_{b, \min }
$$

O detalhe da armadura em questão é mostrado na figura 4.15. A armadura fica posicionada acima das bases de concreto das vigotas com armação treliçada. 


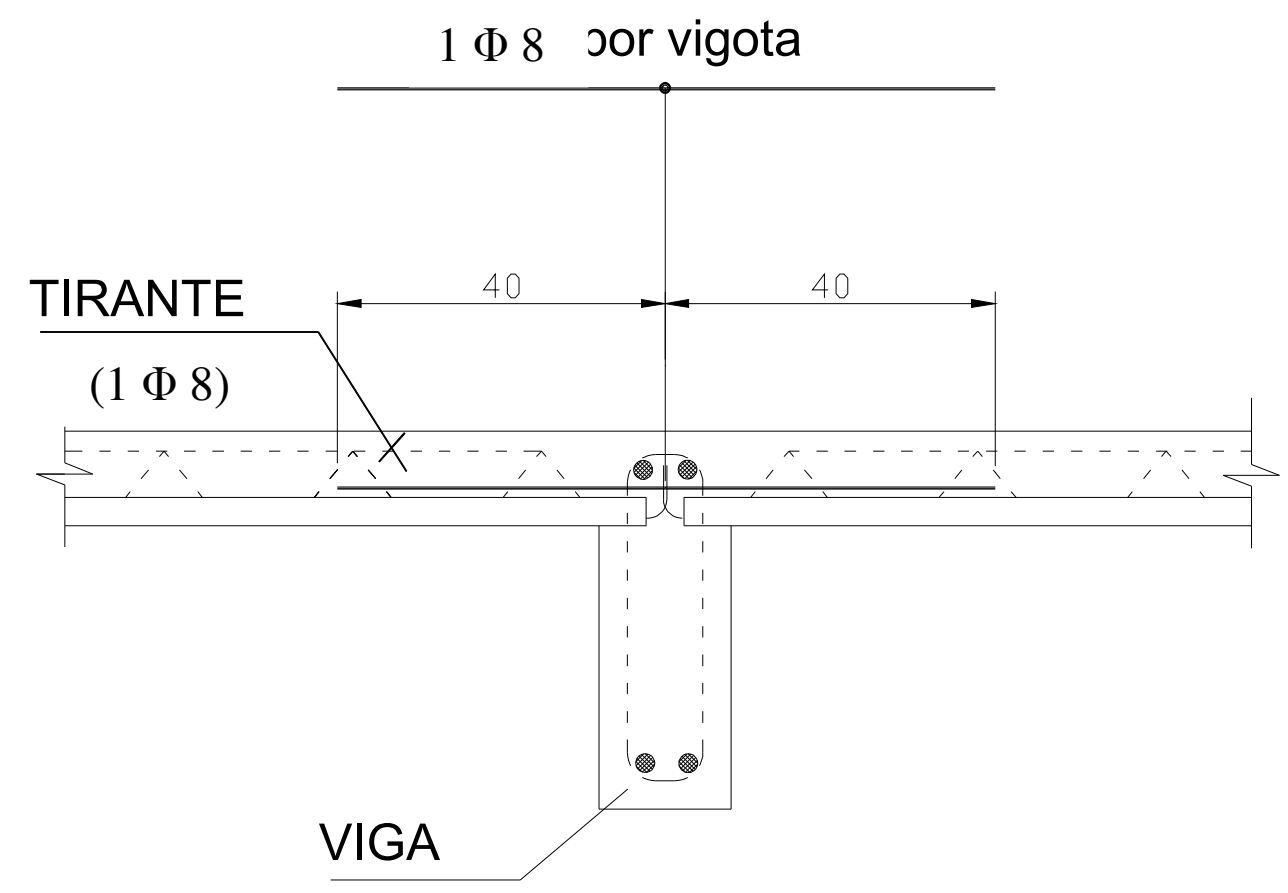

Figura 4.15 - Detalhamento da armadura contra o colapso progressivo (corte na seção transversal)

O consumo de aço adicional para o pavimento e combater um eventual colapso progressivo é de, aproximadamente, $9 \mathrm{~kg}$. Valor correspondente apenas às ligações entre as lajes L1 e L3. O valor é irrisório e comparado ao consumo total de aço do pavimento em geral. Para todo o pavimento, tem-se que o consumo total de aço a ser utilizado com a armadura para combater o colapso progressivo é de $31 \mathrm{~kg}$.

\subsection{COMPARAÇÃO ENTRE CONSUMO DE MATERIAIS: LAJE MACIÇA x LAJE PRÉ-MOLDADA}

Com base na opção original de lajes maciças, é feita uma comparação de consumo de concreto, fôrmas e aço entre as duas opções: lajes maciças e lajes formadas por vigotas treliçadas pré-moldadas. O resultado final para os dois casos está exposto na tabela 4.12 . 
Tabela 4.12 - Consumo de materiais das opções de lajes maciças e pré-moldadas para o pavimento analisado

\begin{tabular}{c|c|c|c}
\hline & CONCRETO & FÔRMAS & AÇO \\
\hline MACIÇAS & $17 \mathrm{~m}^{3}$ & $167 \mathrm{~m}^{2}$ & $690 \mathrm{~kg}$ \\
\hline PRÉ-MOLDADAS & $11 \mathrm{~m}^{3}$ & - & $600 \mathrm{~kg}$ \\
\hline
\end{tabular}

Os consumos de aço são referentes à soma de todas as treliças das lajes, armação negativa (principal e de distribuição) e tela de aço na capa de concreto (Ф5mm c/ 25cm).

\subsection{SÍNTESE DOS RESULTADOS E ANÁLISES}

A análise dos deslocamentos das lajes no exemplo de aplicação mostra que, para uma mesma altura, as lajes formadas por vigotas com armação treliçada apresentam flechas maiores que as lajes maciças. Em média, a diferença entre os valores é de cerca de quatro a três vezes maiores.

Para as vibrações causadas pela caminhada, a análise aponta que a laje formada por vigota com armação treliçada de $10 \mathrm{~cm}$, possibilita um vão máximo bem reduzido, 3 metros. Isto significa que as lajes pré-moldadas com as características descritas no exemplo não podem ter vãos maiores que 3 metros. Como esse exemplo é representativo do que se faz hoje no Brasil, este limite é um alerta para que se faça sempre esta verificação. Neste caso, seria necessário alterar a altura da laje para $12 \mathrm{~cm}$. Portanto, a verificação das vibrações excessivas é determinante no dimensionamento das lajes.

A redistribuição do momento negativo nos apoios no exemplo de aplicação resulta em uma uniformização dos momentos fletores, ajudando na economia de materiais. Isto porque é comum no meio técnico o dimensionamento da laje quanto ao momento fletor positivo calculando-a como simplesmente apoiada. Fornece, assim, um momento fletor alto e armadura 
também. Além disso, coloca-se armadura negativa construtiva nos apoios. Tudo isso somado resulta em um alto consumo de aço. A redistribuição racionaliza 0 dimensionamento.

$\mathrm{Na}$ análise das flechas ao longo do tempo segundo Merlin (2006), os resultados do exemplo mostram a diferença com a norma brasileira NBR 6118:2003 e como são subestimados. Isto também foi observado por Merlin (2006) em seus estudos com várias alturas de lajes formadas por vigotas treliçadas.

Através de um cálculo simples baseado na norma britânica BS 8110, área de aço resultante do tirante foi obtida e, comparado com o consumo total de aço, o "investimento" nas armaduras contra o colapso progressivo é baixo. A NBR 6118:2003 não obriga a adoção de tal armadura. 



\section{CONSIDERAÇÕES FINAIS E CONCLUSÕES}

O intuito deste trabalho foi de fornecer recomendações de projeto com base nas bibliografias disponíveis e mostrar, através de exemplo de aplicação, as verificações fundamentais para o projeto de lajes formadas por vigotas com armação treliçada.

Com base nas recomendações de projeto, podem-se destacar alguns pontos importantes:

a) As nervuras transversais às vigotas são fundamentais, apesar de não serem obrigatórias pela norma brasileira. Como foi dito, auxiliam muito na distribuição de cargas concentradas. Somente as vigotas com armação treliçada permitem estas nervuras.

b) $\mathrm{O}$ maciçamento das regiões próximas aos apoios. A norma espanhola EF-96 (1997) impõe ao menos $10 \mathrm{~cm}$ entre a face do apoio e o início dos elementos de enchimento. Para o EUROCODE (2002), o mínimo é de $20 \mathrm{~cm}$. Isto demonstra o quanto importante é esta região maciça.

c) A espessura da capa de concreto. O mínimo permitido pela NBR 14859-1 é de $3 \mathrm{~cm}$. Já o EF-96 (1997) indica no mínimo $4 \mathrm{~cm}$. Foi visto e discutido os benefícios da espessura da capa ser maior que 3 $\mathrm{cm}$.

d) A análise não-linear fornece um comportamento mais próximo do real para a estrutura. A consideração da seção fissurada, a fluência 
do concreto e a rigidez final dos elementos são alguns dos benefícios trazidos por esta análise.

O exemplo de aplicação foi proposto para mostrar os maiores problemas enfrentado pelo engenheiro civil no dimensionamento destas lajes. Procurou-se aproximar ao máximo de um projeto comum da área. Medidas dos vãos, resistência do concreto à compressão e espessura da laje foram algumas das características comuns dos projetos incorporadas ao exemplo. Dentre as análises feitas dos estados limites de serviço, do momento negativo nos apoios e do colapso progressivo, nota-se que:

a) De fato, as lajes formadas por vigotas com armação treliçada são mais susceptíveis às flechas quando comparadas com as lajes maciças de mesma altura, de acordo com o exemplo de aplicação. Cerca de quatro vezes maior o deslocamento, tanto nas análises linear quanto na não-linear.

b) A análise das flechas ao longo do tempo, segundo MERLIN (2006), demonstra o quanto a NBR 6118:2003 subestima os valores do coeficiente multiplicador das flechas iniciais. Determinou-se, para o exemplo, através da análise probabilística, que o fator é de 2,20 e a norma brasileira propõe 1,47 . Uma diferença de $50 \%$.

c) Para o ELS-DEF, a laje formada por vigotas com armação treliçada não atende à NBR 6118:2003 quanto à aceitabilidade sensorial segundo a limitação visual do deslocamento quando comparada com a flecha final da laje L3.

d) A redistribuição de $60 \%$ do momento negativo no apoio garante uma economia de materiais, tanto de concreto quanto de aço, já que equaliza os momentos fletores, como foi feito no exemplo de aplicação. Sem a redistribuição, seria obrigatório o maciçamento da região próxima aos apoios para garantir a seção de concreto comprimida necessária para equilibrar a seção. 
e) $\mathrm{Na}$ análise das vibrações provocadas pela caminhada para este tipo de laje, dependendo do vão e altura da laje, facilmente não apresentam as características necessárias para que os limites estabelecidos por norma sejam seguidos. Isto mostra que é um ponto crítico no dimensionamento das lajes formadas por vigotas com armação treliçada.

f) Comparadas com as lajes formadas por vigotas com armação treliçada, os vãos máximos admissíveis para estas lajes são $28 \%$ inferiores às lajes maciças para uma mesma altura. Para o exemplo proposto, é preciso alterar a altura da laje para $12 \mathrm{~cm}(\mathrm{LT} 8+4)$ para que o ELS-VE seja atendido.

g) Mesmo com $12 \mathrm{~cm}$ de altura, o vão máximo permitido para a laje na vibração por caminhada foi de $3,35 \mathrm{~m}$. Valor este igual ao vão da laje analisada. Isto mostra que a laje está no limite da verificação.

h) No exemplo aplicado ao colapso progressivo, um pequeno aumento de $5 \%$ no consumo de aço para as lajes de um pavimento fornece mais segurança à estrutura. Realizado através de um cálculo simples. É necessário, entretanto, que a norma brasileira seja revisada, com todos os métodos, coeficientes e equações. Para isso, são necessárias mais pesquisas acadêmicas e discussões sobre o tema.

i) Acidentes recentes servem de alerta para que engenheiros civis e construtoras estudem a fundo o colapso progressivo. E quando se trata de evitar a perda de vidas humanas, um aumento irrisório no consumo de aço não reflete o benefício trazido por esta solução. Mesmo para as lajes maciças podem-se empregar as armaduras (tirantes) no combate ao colapso progressivo.

Deve ficar claro que este trabalho está restrito para os casos de lajes formadas por vigotas treliçadas. Além disso, o exemplo de aplicação está limitado a certa relação de vãos, sem cargas concentradas e outras dificuldades 
que possam surgir no dimensionamento. Tudo para facilitar os cálculos e o entendimento do problema.

Outro intuito desta dissertação é incentivar a discussão sobre o tema do colapso progressivo no meio técnico e acadêmico, além de destacar a importância da verificação não só das flechas, mas também das vibrações. Apesar de ser obrigatória, dificilmente observa-se esta verificação nos escritórios de cálculo estrutural no país.

Uma sugestão para trabalhos futuros é a consideração nos cálculos das flechas e vibrações das lajes a espessura adicional do piso e revestimento. Este aumento, de aproximadamente $1 \mathrm{~cm}$ a $3 \mathrm{~cm}$, trará um melhor desempenho da laje quanto a estes aspectos que são primordiais para este tipo de laje. A adoção de blocos cerâmicos ou de concreto também ajuda a combater as vibrações, já que possuem peso próprio maior que os blocos de poliestireno expandido (EPS). 




\section{REFERÊNCIAS BIBLIOGRÁFICAS}

ALMEIDA, S.F.; NÓBREGA, P.G.B.; HANAI, J.B. (2004) Análise de vibrações de pisos de concreto pré-moldado. [CD-ROM]. Anais do $46^{\circ}$ CONGRESSO BRASILEIRO DO CONCRETO. Florianópolis, SC. 2004.

ALMEIDA, S.F. (2005) Análise dinâmica experimental da rigidez de elementos de concreto submetidos à danificação progressiva até a ruptura. Dissertação. (Mestrado). Escola de Engenharia de São Carlos, Universidade de São Paulo, São Carlos, 2005.

ALMEIDA, S. F.; NÓBREGA, P. G. B.; HANAI, J.B. (2005) Critérios de Vibração para Estruturas de Piso de Concreto Pré-moldado. In: $1^{\circ}$ Encontro Nacional de Pesquisa-Projeto-Produção em Concreto Pré-moldado, 2005, São Carlos. Livro de Resumos do $1^{\circ}$ Encontro Nacional de Pesquisa-ProjetoProdução em Concreto Pré-moldado, v. 1. p. 9-9. 2005.

ASSOCIAÇÃO BRASILEIRA DE NORMAS TÉCNICAS. (2003). NBR 6118 - Projeto de Estruturas de Concreto: Procedimento. Rio de Janeiro, 2003.

ASSOCIAÇÃO BRASILEIRA DE NORMAS TÉCNICAS. (1980). NBR 6120 - Cargas para o cálculo de estruturas de edificações. Rio de Janeiro, 1980.

ASSOCIAÇÃO BRASILEIRA DE NORMAS TÉCNICAS. (2006). NBR 9062 - Projeto e Execução de Estruturas de Concreto Pré-Moldado. Rio de Janeiro, 2006.

ASSOCIAÇÃO BRASILEIRA DE NORMAS TÉCNICAS. (2002). NBR 14859-1 -Laje pré-fabricada - Requisitos - Parte 1: Lajes unidirecionais. Rio de Janeiro, 2002. 
ASSOCIAÇÃO BRASILEIRA DE NORMAS TÉCNICAS. (2002). NBR 14859-2 -Laje pré-fabricada - Requisitos - Parte 1: Lajes bidirecionais. Rio de Janeiro, 2002.

ASSOCIAÇÃO BRASILEIRA DE NORMAS TÉCNICAS. (1980). NBR 15200 - Projeto de estruturas em situação de incêndio - Procedimento. Rio de Janeiro, 2004.

AVILLA JUNIOR, J. (2009) Contribuição ao projeto e execução de lajes lisas nervuradas pré-fabricadas com vigotas treliçadas. Dissertação (Mestrado). Programa de Pós-Graduação em Construção Civil. Universidade Federal de São Carlos. São Carlos, SP. 2005.

BAILEY, C.G. (2004) Membrane action of slab/beam composite floor systems in fire. Engineering Structures, v.26, p. 1691-1703.

BRANSON, D.E. (1968). Design procedures for computing deflections. Journal of American Concrete Institute, v.65, n.9, p.730-42.

BUIATE, M. (2004). Estudo do comportamento de lajes nervuradas formadas por vigotas de concreto com armação tipo treliçada e vigas de borda. Dissertação (Mestrado). FECIV. Universidade Federal de Uberlândia. Uberlândia, MG. 2004.

BUIATE, M., LIMA, M.C.V., (2005) Análise do comportamento de lajes nervuradas formadas por vigotas treliçadas e sua interação com as vigas de borda. $1^{\circ}$ Encontro Nacional de Pesquisa-Projeto-Produção em Concreto Pré-Moldado, São Carlos. 2005.

CAIXETA, D.P. (1998) Contribuição ao estudo de lajes pré-moldadas com vigotas treliçadas. Dissertação (Mestrado). Universidade Estadual de Campinas. Campinas, SP.

CARVALHO, R.C. (1994) Análise não-linear de pavimentos de edifícios de concreto através da analogia de grelha. 218p. Tese (Doutorado). Escola de Engenharia de São Carlos, Universidade de São Paulo, 1994. 
CARVALHO, R.C, PARSEKIAN,G.A, FIGUEIREDO FILHO, J.R., MACIEL, A.M (2005) Estado da arte do cálculo das lajes pré-fabricadas com vigotas de concreto.$^{\circ}$ Encontro Nacional de Pesquisa-Projeto-Produção em Concreto Pré-Moldado, São Carlos. 2005.

CARVALHO, R.C, FIGUEIREDO FILHO, J.R., JUNIOR, S.F., MESQUITA, V.V. (2000) Escolha da altura de lajes com nervuras pré-moldadas para pavimentos de edificações considerando as verificações do estado limite último e de deformação excessiva. XXIX Jornadas Sud Americanas de Ingeniaria Estructural, 2000, Punta del Este, Uruguai. Memorias Del Jubileo profo Julio Ricaldonil. Montevideo, URUGUAY : Universidad de la Republica.

CARVALHO, R.C.,FIGUEIREDO FILHO, J.R. (2005). Cálculo e detalhamento de estruturas usuais de concreto armado. $2^{a}$ Edição - Editora da UFSCar. São Carlos, SP.

CHEN, Y.(1999) "Finite element analysis for walking vibration problems for composite precast building floors using ADINA: modeling simulation, and comparison". Computers and Structures, v.72, n.7, p.109-126.

COMITE EURO-INTERNATIONAL DU BETON (1998). Ductilility of reinforced concrete structures. Bulletin d'Information, n. 242.

COMITE EURO-INTERNATIONAL DU BETON (1998). CEB-FIP. Guide to Good Practice, Composite floor structures. Lausanne, Switzerland.

COMITE EURO-INTERNATIONAL DU BETON (2008). CEB-FIP Structural connections for precast concrete buildings. Bulletin 43. Lausanne, Switzerland.

COSTA, C.N. (2008) Dimensionamento de elementos de concreto armado em situação de incêndio. 721p. Tese (Doutorado) - Escola Politécnica, Universidade de São Paulo, São Paulo, 2008. 
DIÓGENES, H. J. F. (2010) Análise tipológica de elementos e sistemas construtivos pré-moldados de concreto do ponto de vista de sensibilidade a vibrações em serviço. 210p. Dissertação (Mestrado) - Escola de Engenharia de São Carlos, Universidade de São Paulo, São Carlos, 2010.

DROPPA Jr., A. (1999). Análise estrutural de lajes formadas por elementos pré-moldados tipo vigota com armação treliçada. 177p. + apêndice. Dissertação (Mestrado) - Escola de Engenharia de São Carlos, Universidade de São Paulo, 1999.

DROPPA JÚNIOR A., EL DEBS M. K. (2000). Um estudo teóricoexperimental do comportamento estrutural de vigotas e painéis com armação treliçada na fase de construção [CD-ROM]. $42^{\circ}$ Congresso Brasileiro do Concreto. São Paulo, SP.

EL DEBS, M.K. (2000) Concreto pré-moldado: fundamentos e aplicações. São Carlos. Projeto REENGE. EESC - USP.

ELLIOT, K.S. (1996). Multi-storey precast concrete framed structures. Oxford: Blackwell Science.

ESPAÑA. (1997). Ministerio de Fomento. EF-96 - Instrucción para el proyecto y la ejecución de forjados unidireccionales de hormigón armado 0 pretensado. Madrid, Centro de Publicaciones. (Series normativas. Instrucciones de construcción).

EUROPEAN COMMITTEE FOR STANDARDIZATION (2004). prEN 15037-1. Precast concrete products - Beam-and-block floor systems - Part 1: Beams. Brussels, 2004.

EUROPEAN COMMITTEE FOR STANDARDIZATION (2004) prEN 150372. Precast concrete products - Beam-and-block floor systems - Part 2: Blocks. Brussels, 2004.

FIGUEIREDO FILHO, J. R.; SHIRAMIZU A. K. H. (2011) Projeto, Produção e Execução de Edificações com Lajes Pré-Moldadas Treliçadas. Revista Ibracon de Estruturas e Materiais, v.4, n.1, p.123-146. 
FIGUEIREDO FILHO, J; AVILLA JR., J; CARVALHO, R.C. (2005) Pavimentos de lajes pré-moldadas:efeito de nervuras de travamento na determinação das reações nas vigas de contorno. . [CD-ROM]. Anais do $4^{\circ}{ }^{\circ}$ CONGRESSO BRASILEIRO DO CONCRETO. Recife, PE

GIONGO, J.S. (2007) Concreto Armado: Dimensionamento de elementos estruturais lineares submetidos à ação de momento fletor. EESC, USP. São Carlos, SP. 2007.

GOMIDE, K. A.; MORENO Jr., A. L. (2009) Lajes pré-fabricadas em situação de incêndio. $2^{\circ}$ Encontro Nacional de Pesquisa-Projeto-Produção em Concreto Pré-Moldado, São Carlos.

GUARDA, M.C.C.; RAMALHO, M. A.; CORRÊA, M.R.S.(2006) Avaliação dos deslocamentos diferidos no tempo de lajes em concreto armado. Anais do VI Simpósio EPUSP sobre Estruturas de Concreto, São Paulo, SP.

KATAOKA, L.T. (2005) Estudo experimental da deformação ao longo do tempo de lajes contínuas e simplesmente apoiadas executadas com vigotas pré-moldadas de concreto. Dissertação (Mestrado). Universidade Federal de São Carlos. São Carlos, SP. 2005

LARANJEIRAS, A.C.R. (2011) Colapso progressivo dos edifícios: breve introdução. Disponível em: <http://www.tqs.com.br/tqs-news/downloaddo-tqs-news/doc_download/50-no-33-agosto11-artigo-antonio-carlos-reislarangeiras >. Acesso em: 13 out. 2011.

MAGALHÃES, F.L. (2001). Estudo dos momentos fletores negativos nos apoios de lajes formadas por elementos pré-moldados tipo nervuras com armação treliçada. São Carlos. 135p. + apêndice. Dissertação (Mestrado) - Escola de Engenharia de São Carlos, Universidade de São Paulo.

MAST, R.F. (2001) Vibration of precast prestressed concrete floors. PCI Journal, nov-dec/2001. p. 76-86. 
MEDRANO, M. L. O.; FIGUEIREDO FILHO, J.R.; (2006) Estudo de pavimentos de lajes com vigotas pré-moldadas: influência de nervuras transversais na distribuição do carregamento nas vigas de contorno. Anais do $48^{\circ}$ Congresso Brasileiro do Concreto. Rio de Janeiro, RJ.

MEDRANO, M. L. O.; FIGUEIREDO FILHO, J.R.; CARVALHO, R.C. (2005) Estudo de pavimentos de lajes formados por vigotas pré-moldadas: influência de nervuras transversais. $1^{\circ}$ Encontro Nacional de PesquisaProjeto-Produção em Concreto Pré-Moldado, São Carlos

MERLIN, A. J. (2002). Momentos fletores negativos nos apoios de lajes formadas por vigotas de concreto protendido. São Carlos, 2002. 134p. Dissertação (Mestrado) - Escola de Engenharia de São Carlos, Universidade de São Paulo, 2002.

MERLIN, A. J. (2006). Análise probabilística do comportamento ao longo do tempo de elementos parcialmente pré-moldados com ênfase em flechas de lajes com armação treliçada. São Carlos, 2006. 212p + apêndice. Tese (Doutorado) - Escola de Engenharia de São Carlos, Universidade de São Paulo, 2006.

MERLIN, A. J.; KATAOKA, L.T.; ROGGE, A.C.; FIGUEIREDO FILHO, J.F.; CARVALHO, R.C.; EL DEBS, M.K. (2005) Estudo teórico-experimental para previsão de flechas ao longo do tempo de lajes pré-moldadas considerando a fissuração do concreto. [CD-ROM]. Anais do $47^{\circ}$ CONGRESSO BRASILEIRO DO CONCRETO. Recife, PE

MEHTA, P.K.; MONTEIRO, P.J.M. (2008). Concreto: estrutura, propriedades e materiais. Tradução da 3. ed. em inglês. São Paulo: Ibracon, 2008. 674p.

MUNIZ. C. E. (1991). Mais competitivas: lajes treliçadas. Revista IBRACON, v.1, n.1, p.19-21, julho, agosto.

MURRAY, T.M.; ALLEN, D.E.; UNGAR, E.E. (1997) Floor vibrations due to human activity. AISC - CISC, Steel Design Guide Series, v.11. 1997. 
NATIONAL INSTITUTE OF STANDARDS AND TECHNOLOGY, U.S. (2007) - Best Practices for Reducing the Potential for Progressive Collapse in Buildings. NISTIR 7396. $216 \mathrm{p}$.

PUMA - ARMAÇÃO TRELIÇADA (2003). Manual de fabricação - lajes treliçadas. São Paulo.

Disponível em <http://www.puma.com.br/downloads.php>. Acesso em: 10 jul. 2011.

ROGGE, A. C.; TIRINTAN, M. R. A.; CARAVLHO, R. C.; SYDNEY, F. Jr.; FIGUEIREDO FILHO, J. R.. (2002) Estudo experimental da deformação ao longo do tempo em lajes com vigotas pré-moldadas. XXX Jornadas SulAmericanas de Engenharia Estrutural. Brasília, GO.

SANTINI, C.R.; KATAOKA, L.T.; MELLO, A.L.V.; CARVALHO, R.C.; FIGUEIREDO FILHO, J.R. (2004) Análise de vibrações de pisos de concreto pré-moldado. [CD-ROM]. Anais do 46을 CONGRESSO BRASILEIRO DO CONCRETO. Florianópolis, SC

TERNI, A.W.; FERREIRA, J.B., OLIVEIRA, J.E. de, HIRATA, M.S. (2004) Sobre a comparação dos valores normativos nominais e os valores experimentais da resistência ao cisalhamento da solda entre o banzo superior e os diagonais das soldas das armações treliçadas utilizadas em lajes pré-fabricadas. [CD-ROM]. Anais do $46^{\circ}$ CONGRESSO BRASILEIRO DO CONCRETO. Florianópolis, SC

ZHANG, N.S., LI, G.Q., LOU, G.B., JIANG, S.C., H, K.C. (2009). Experimental study on full scale composite floor slabs under fire condition. Proceedings of International Applications of Structural Fire Engineering, p.502511. Praga, República Tcheca. 